Camila Silva Leal

Estudo Comparativo da Organização do Sistema Digestivo de Representantes das Ordens Hemiptera e Thysanoptera

Comparative study of the Organization of the Digestive System of Representative Species of the Orders Hemiptera and Thysanoptera

São Paulo

2018 


\section{Estudo Comparativo da Organização do Sistema Digestivo de Representantes das Ordens Hemiptera e Thysanoptera}

\section{Comparative study of the Organization of the Digestive System of Representative Species of the Orders Hemiptera and Thysanoptera}

Dissertação apresentada ao Instituto de Biociências da Universidade de São Paulo, para a obtenção de Título de Mestre em Ciências Biológicas, na área de Biologia/Genética.

Orientador: Prof. Dr. Alberto de Freitas Ribeiro

São Paulo 


\section{Ficha Catalográfica}

Leal, Camila Silva

Estudo comparativo da organização do sistema digestivo de representantes das ordens Hemiptera e Thysanoptera / Camila Silva Leal; orientador Alberto Augusto Gonçalves de Freitas Castro Ribeiro. -- São Paulo, 2018.

$141 \mathrm{f}$.

Dissertação (Mestrado) - Instituto de Biociências da Universidade de São Paulo, Departamento de Genética e Biologia Evolutiva.

1. Sistema digestivo. 2. Insetos. 3. Hemiptera. 4. Thysanoptera. 5. Morfologia. I. Ribeiro, Alberto Augusto Gonçalves de Freitas Castro, orient. II. Título. 


\section{Comissão Julgadora}

Prof(a). Dr(a).

Prof(a). Dr(a).

Prof(a). Dr(a).

Prof. Dr. Alberto de Freitas Ribeiro

(Orientador) 


\section{Dedicatória}

Dedico este trabalho à minha mãe, que foi o meu maior apoio nos momentos de angústia, minha maior incentivadora nos momentos de dúvida, por me amar pelo que eu realmente sou e por nunca ter duvidado de mim. Obrigada mãe.

Devo todas as minhas conquistas à minha família, por todo o suporte, todos os puxões de orelha, todas as alegrias e tristezas compartilhadas. Obrigada por todo o amor que me deram e pela vida que me proporcionaram. 


\section{Agradecimentos}

Ao orientador e amigo Prof. Dr. Alberto de Freitas Ribeiro, por sua orientação, por ter sempre feito mais do que the cabia e pela preocupação, carinho e incentivo que me ajudaram a concluir esse trabalho.

Ao Prof. Dr. Walter Ribeiro Terra, por toda sua orientação e por disponibilizar a estrutura do Laboratório de Bioquímica de Insetos (IQ-USP) e toda sua equipe para a realização da etapa final do projeto.

Ao Prof. Dr. João Roberto Spotti Lopes, por fornecer exemplares das espécies Dalbulus maidis e Peregrinus maidis utilizadas neste estudo, além de disponibilizar a estrutura do Laboratório de Insetos Vetores de Fitopatógenos (Entomologia - ESALQ/USP) e sua equipe para a realização deste trabalho.

À Profa. Dra. Mariz Vainzof, coordenadora do Curso de Pós-Graduação do Programa de Ciências Biológicas/Genética, por todo o suporte e assistência prestada ao longo de todo o período de desenvolvimento da dissertação.

Ao amigo e companheiro de laboratório Márcio Valentim Cruz, por todo o suporte técnico, pelos momentos de descontração e pela boa companhia dos últimos anos.

Ao companheiro de laboratório Waldir Caldeira, não apenas por ter sido um poço de conhecimento técnico, mas por todas as conversas e conselhos sobre a vida e por ter sido meu melhor amigo durante toda essa jornada.

À amiga Sheila, por toda a amizade e prestatividade e por desempenhar quase tão bem como eu as minhas atribuições complementares no laboratório.

Ao amigo Alexandre Utiyama, por toda a ajuda, todas as discussões acadêmicas e filosóficas, pela companhia, pelas viagens e pelos bons momentos.

Aos colegas Fabrício e Elisa, pelo trabalho de identificação das espécies de Thysanoptera, pelas viagens de coleta e por me ajudarem com todas as dúvidas sobre a sistemática do grupo. 
Ao amigo José Raul, sua querida família e companheiros de laboratório, pela recepção tão calorosa, pela disposição em ajudar e pela disponibilização do laboratório para realização da pesquisa. À EMBRAPA - Gado de Corte pela disponibilização dos espécimes de Mahanarva fimbriolata.

À Erika Harumi Takamoto de Camargo, da Secretaria de Pós-Graduação do IB-USP, por toda a ajuda e assistência prestada em todos estes anos de pós-graduação.

À Adriana Hypólito Nogueira, diretora técnica do Serviço de Biblioteca do IB-USP, por fornecer apoio bibliográfico com obras de difícil acesso.

Aos meus amados pais Adiva e Celso, pelo suporte, carinho, incentivo e principalmente pelo amor não só durante essa jornada, mas durante toda a minha vida.

À minha irmã preferida Daniele, que, do dia pra noite, tornou-se a minha melhor amiga e ao meu cunhado Douglas. Obrigada por alegrarem esse período da minha vida com o maior presente que eu já recebi.

Aos meus amigos e colegas de profissão Thais, Tatiene, Kleber, Adauto, Felipe, Sarah, Gabriel, Leo e Andrea, por todas as provas, festas, viagens, trabalhos, grupos de estudo, seminários, gargalhadas, churrascos e obrigada pela praça do relógio. Vocês fizeram os últimos anos valerem a pena.

Aos meus primos do coração Jacson, Pamela, Raphael, Silvio, Thiago, Daiana e Márcia, por toda a preocupação, apoio, amizade e noites de tranca por toda a minha vida.

À toda a minha família, que eu precisaria de outra dissertação apenas para descrever o quanto os amo e o quanto fizeram não só por mim, mas por meus pais e minha irmã por toda a nossa vida e, principalmente, nos últimos anos.

A todos os grandes amigos que me acompanharam ao longo dos anos de desenvolvimento da dissertação, que fizeram a jornada valer a pena.

À CAPES e FAPESP pelo apoio financeiro. 
Finalmente, ao meu marido Luis, sem o qual eu provavelmente teria desistido da faculdade antes de passar em bioquímica. Você é o que me faz feliz. 


\section{Lista de Abreviaturas}

B - Brocossomos

CF - Câmara de filtração

CVC - Clorose variegada dos citros

CLM - Complexo Luminal de Membranas

DC - Domínio cônico do intestino médio

DT - Domínio tubular do intestino médio

E - Esôfago

EPM - Espaço perimicrovilar

FLM - Flame-like membranes

G - Complexo de Golgi

CMV - Corpo multivesicular

IM - Intestino médio

IMa - Intestino médio anterior

IMp - Intestino médio posterior

IMPB - Invaginações da membrana plasmática basal

IP - Intestino posterior

L - Lúmen

LB - Lâmina Basal

MET - Microscopia eletrônica de transmissão

MEV - Microscopia eletrônica de varredura

Mi - Mitocôndrias 
Mv - Microvilosidades

MP - Membrana peritrófica

MPM - Membranas perimicrovilares

MPMm - Membranas perimicrovilares modificadas

MLC - Membranas luminais em forma de chama

MLCm - Membranas luminais em forma de chama modificadas

N - Núcleo

PMM - Perimicrovillar membranes

PMMm - Modified perimicrovillar membranes

$\mathbf{R}$ - Reto

RE - Retículo endoplasmático

TM - Túbulos de Malpighi

V - Vesículas do complexo de Golgi

VS - Vesícula de secreção 


\section{Sumário}

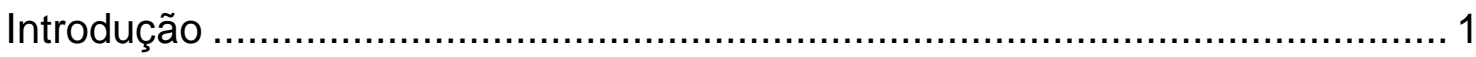

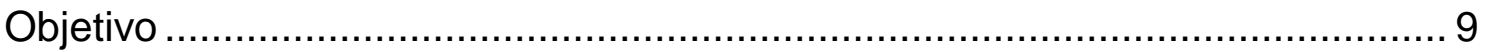

Material e Métodos .................................................................................. 11

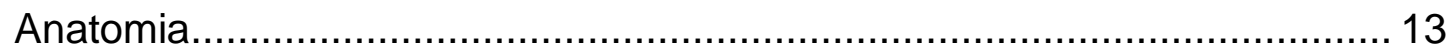

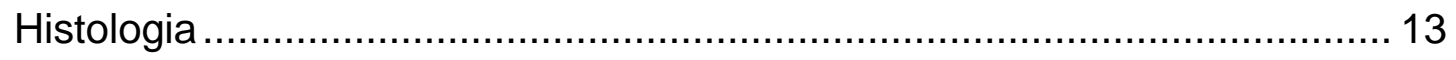

Microscopia de Fluorescência Confocal ............................................ 14

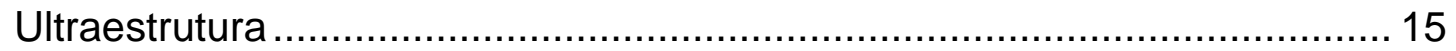

Microscopia eletrônica de transmissão (MET) …................................... 15

Microscopia Eletrônica de Varredura (MEV) ..................................... 16

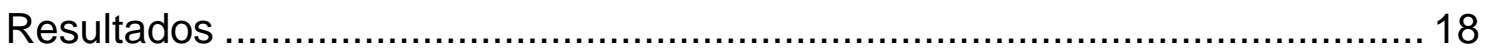

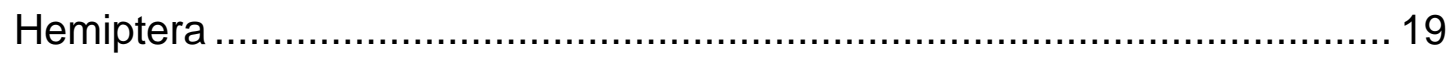

Mahanarva fimbriolata.................................................................... 19

Dalbulus maidis ............................................................................... 22

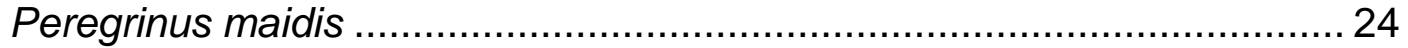

Visualização do CLM por Microscopia de Fluorescência Confocal ........... 25

Thysanoptera .............................................................................. 26

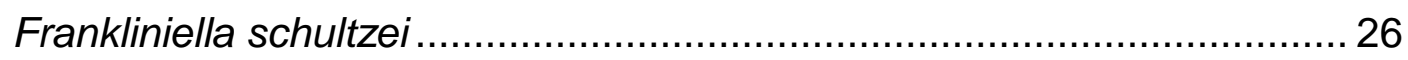

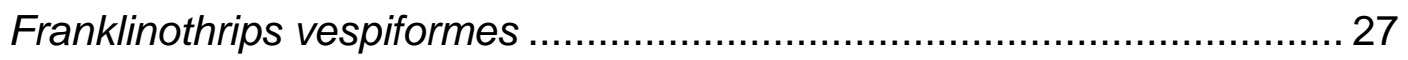

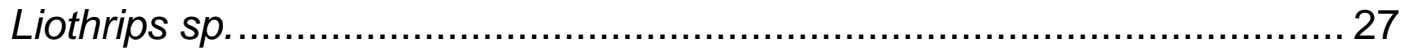

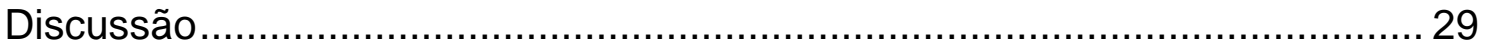

Panorama do Sistema Digestivo em Condylognatha.............................. 39

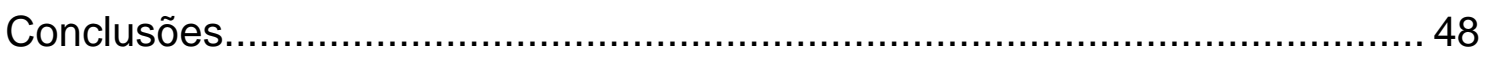

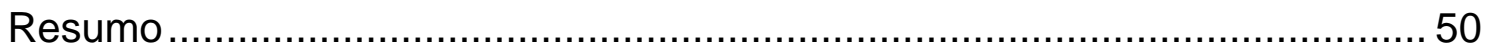

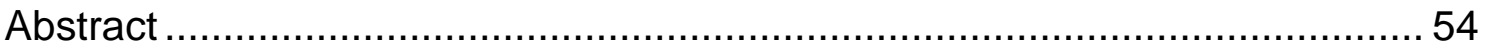

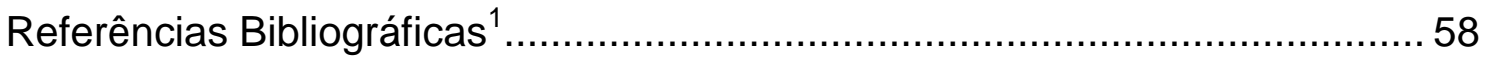

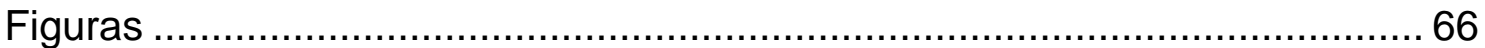


Introdução 
Os insetos constituem a maior classe animal existente. Com cerca de um milhão de espécies, eles representam aproximadamente $70 \%$ de todas as espécies animais (Rupert \& Barnes, 1996). O grande sucesso evolutivo desse grupo pode ser atribuído, em parte, ao longo tempo de colonização do planeta, pois de acordo com o registro fóssil, as primeiras espécies de insetos surgiram no período Devoniano, há cerca de 400 milhões de anos. A partir de então, e de acordo com diferentes pressões seletivas, desenvolveram uma grande variedade de estruturas adaptativas, possibilitando a dispersão da classe para diferentes regiões do globo (Gillot, 1995). A grande diversidade morfofisiológica dos insetos tornou possível a ocupação de diversos nichos ecológicos e, hoje, quase toda a matéria orgânica disponível na natureza pode servir de alimento para eles (Terra, 1988).

Esse grande sucesso evolutivo e a ampla distribuição geográfica resultante, acarreta consequências aos seres humanos, fazendo dos insetos um grupo particularmente importante. Dentre os problemas que podem ser causados por insetos ao homem podem-se citar prejuízos à agricultura, uma vez que há grupos de insetos que são pragas de lavouras, e à saúde pública, com a presença de diversas espécies vetores de doenças. Além disso, os insetos são hoje os maiores competidores dos seres humanos por alimento. Com uma vasta gama de possibilidades na alimentação, o sistema digestivo desses animais sofreu diversas alterações anatômicas, morfológicas e fisiológicas de acordo com as pressões seletivas impostas pelo ambiente em que vivem, cujos detalhes ainda são pouco conhecidos para diversos grupos de insetos.

Nas últimas décadas, ampliou-se a pesquisa no campo dos processos digestivos em insetos, com ênfase na biologia celular e molecular das células intestinais, incluindo os mecanismos de secreção a caracterização das enzimas digestivas desses animais, bem como sua distribuição ao longo do sistema digestivo (Dias et al., 2018; Pimentel et al., 2017; Utiyama et al., 2017). Esperase que um maior conhecimento nessa área leve, entre outras consequências práticas, ao desenvolvimento de inibidores específicos de enzimas digestivas que poderão ser usados futuramente em larga escala como uma nova geração de praguicidas. 
O sistema digestivo dos insetos pode ser dividido em três regiões anatômicas principais: o intestino anterior, o intestino médio e o intestino posterior (Wigglesworth, 1972; Chapman, 1998; Terra 1990). Os principais eventos da digestão ocorrem no intestino médio, onde, com exceção principalmente das ordens Hemiptera e Thysanoptera, pode ser observada a presença de uma membrana acelular em sua luz denominada de membrana peritrófica (MP) (Terra et al., 1996; Terra, 2001; Lehane, 1997). Esta membrana separa o conteúdo luminal em dois compartimentos: o espaço endoperitrófico (interior da membrana) e o ectoperitrófico (entre a MP e o epitélio do intestino médio) (Terra, 2001). A MP atua na proteção das células epiteliais contra microorganismos e contra abrasão causada pela passagem do alimento (Terra, 2001). Porém, sua função primordial é a de compartimentalizar o processo digestivo, permitindo uma recirculação endo-ectoperitrófica de enzimas digestivas, tornando o processo da digestão mais eficiente e econômico para o organismo, reduzindo significativamente a taxa de excreção dessas enzimas (Terra, 1988).

As espécies das ordens Hemiptera e Thysanoptera não apresentam uma MP no lúmen do intestino médio, como acima mencionado, mas exibem um complexo luminal de membranas, que se encontra em íntima associação com as microvilosidades do epitélio intestinal. Em algumas espécies, este sistema se apresenta como membranas lipoproteicas que revestem as microvilosidades da superfície apical dos enterócitos, sendo denominadas de membranas perimicrovilares (MPM) (Lane \& Harrison, 1979). Estas membranas revestem as microvilosidades a uma distância regular e suas extremidades se projetam em direção ao lúmen, terminando em fundo cego. Cria-se, assim, um compartimento, denominado espaço perimicrovilar (EPM), delimitado pela membrana plasmática das microvilosidades e a membrana perimicrovilar (Silva et al., 1995; Terra, 2001).

A ausência da membrana peritrófica em Hemiptera e Thysanoptera está, provavelmente, relacionada à adaptação do ancestral destes grupos, que utilizava a seiva das plantas como alimento, como sugerido pela evolução dos aparelhos bucais sugadores em ambos os grupos (Terra, 1988). Pelo fato da seiva ser composta por monômeros e dímeros orgânicos, praticamente 
nenhuma digestão do alimento é necessária, além da hidrólise dos dímeros (Terra, 1988). Esta fonte de alimento é extremamente pobre em aminoácidos, que podem ser absorvidos pelo mecanismo descrito a seguir, dependente da MPM (Terra \& Ferreira, 1994). A membrana das microvilosidades é rica em proteínas integrantes, enquanto que as MPM são pobres nessas proteínas. Possivelmente as microvilosidades devem transportar, ativamente, íons potássio (o íon mais importante na seiva) para o interior dos enterócitos a partir do EPM, formando, deste modo, um gradiente de concentração entre a seiva no lúmen intestinal e o EPM. Este gradiente eletroquímico pode gerar o potencial necessário que permita a absorção ativa de componentes orgânicos, tais como aminoácidos, por proteínas transportadoras apropriadas presentes na membrana perimicrovilar. Uma vez no EPM, os nutrientes orgânicos difundem-se para a membrana das microvilosidades, onde poderão ser incorporados pelos enterócitos por transportadores de membrana específicos (Terra, 1988).

Os hemípteros atuais são capazes de se alimentar tanto de xilema quanto de floema, com algumas espécies que se alimentam de fluido do mesofilo. Em Thysanoptera, o hábito de sucção de fluidos é menos especializado do que o observado em Hemiptera e sua dieta não inclui a seiva das plantas como fonte exclusiva de alimento, uma vez que o comprimento do aparelho bucal dos representantes do grupo normalmente não é longo o bastante para alcançar o sistema vascular das plantas (Grimaldi \& Engels, 2005). Sua dieta é composta por mesofilo e outros tecidos vegetais, além de pequenos artrópodes e fungos nas espécies predadoras e fungívoras, respectivamente.

A existência de MPM foi comprovada por nosso grupo de pesquisa em duas espécies de hemípteros, ambos da subordem Heteroptera: o hematófago Rhodnius prolixus (Hemiptera: Reduviidae) (Ferreira et al., 1988) e o sugador de sementes Dysdercus peruvianus (Hemiptera: Pyrrhocoridae) (Silva et al., 1995; 1996). Por outro lado, um estudo realizado com o afídeo Acyrthosiphon pisum, da subordem Sternorrhyncha (Cristofoletti et al., 2003) evidenciou um segundo tipo de complexo luminal de membranas, diferente das MPM. Neste modelo, são observadas membranas de aspecto enovelado, que foram 
denominadas de membranas perimicrovilares modificadas, associadas às extremidades apicais das lamelas (microvilosidades modificadas) dos enterócitos. Ainda um terceiro modelo de complexo luminal de membranas foi descrito recentemente, também pelo nosso grupo de pesquisa, na espécie Bucephalogonia xanthophis da subordem Auchenorrhyncha. Neste caso membranas associadas às extremidades das microvilosidades dos enterócitos projetam-se em direção ao lúmen, formando figuras semelhantes a chamas. Estas membranas foram chamadas de membranas luminais em forma de chama (MLC) (Utiyama et al., 2017). Estes resultados mostram que o complexo luminal de membranas observado em representantes das diferentes subordens de Hemiptera assume formas muito mais variáveis do que se assumia inicialmente, o que justifica um estudo mais aprofundado deste grupo.

A ordem Hemiptera é um grupo grande e diversificado de insetos sugadores com metamorfose incompleta, que, juntamente com as ordens Thysanoptera, Phthiraptera e Psocoptera, compõem a superordem Paraneoptera (Gillot, 1995; Resh \& Cardé, 2003; Triplehorn \& Johnson, 2005). Os hemípteros variam em morfologia corporal, biologia e hábitos alimentares e são divididos, atualmente, em três subordens: Sternorrhyncha (afídeos e pulgões), Auchenorrhyncha (cigarras e cigarrinhas) e Heteroptera (percevejos) (Gillot, 1995; Resh \& Cardé, 2003; Triplehorn \& Johnson, 2005; Cryan \& Urban, 2011). Enquanto que o monofiletismo de Sternorrhyncha e Heteroptera não são questionados, as relações filogenéticas dos integrantes de Auchenorrhyncha ainda são motivo de discussão. Algumas das classificações mais recentes consideram este grupo parafilético e se referem a este táxon pelas suas duas infra-ordens: Cicadomorpha e Fulgoromorpha (Muséum National D'Histoire Naturelle. Hem-bases). A infraordem Cicadomorpha compreende as superfamílias Cercopoidea, Cicadoidea e Membracoidea, e a infraordem Fulgoromorpha contém apenas a superfamília Fulgoroidea (Resh \& Cardé, 2003; Grimaldi \& Engels, 2005; Cryan \& Urban, 2011). O presente projeto abrange o estudo das espécies de ambas as infraordens, podendo gerar contribuições importantes para a elucidação de aspectos controversos das relações filogenéticas dos hemípteros. 
Integrantes das subordens Sternorrhyncha e Auchenorrhyncha estão adaptados a uma dieta baseada em fluidos vegetais, como o xilema, floema ou mesofilo. Os membros de Heteroptera apresentam a maior diversidade de hábitos alimentares, com espécies sugadoras de seiva, hematófagas e sugadoras de tecidos vegetais e animais (Grimaldi \& Engels, 2005; Triplehorn \& Johnson, 2005). Algumas espécies da subordem Sternorrhyncha e da infraordem Cicadomorpha apresentam uma estrutura anatômica complexa em seu sistema digestivo, denominada de câmara de filtração. Este órgão consiste na aposição entre o intestino médio anterior e o posterior, juntamente com a região proximal dos túbulos de Malpighi (TM), quando presentes, permitindo a passagem do excesso de água presente na seiva das plantas diretamente do intestino anterior para o posterior, concentrando, assim, os nutrientes na porção mediana do intestino médio (Cheung \& Marshall, 1973a, b; Marshall \& Cheung, 1974). Os TM de algumas espécies da subordem Auchenorrhyncha podem apresentar uma região expandida adaptada para a produção e secreção de brocossomos (Raikitov, 1995, 1999; Utiyama, 2011; Utiyama et al., 2017). Os brocossomos são estruturas formadas por lipídios e proteínas com formato estrelado regular e são liberadas pelos TM, sendo enviados ao IP para a excreção. Após serem eliminados pelo ânus, os brocossomos são coletados pelas pernas traseiras e aplicados sobre 0 tegumento, impermeabilizando 0 corpo do inseto.

A ordem Thysanoptera, por sua vez, é composta por cerca de seis mil espécies denominadas, popularmente, de tripes (Mound, L. A., Heming \& Palmer, 1980). Diferentemente dos integrantes da ordem Hemiptera, os tripes são insetos com caracteres morfológicos bem definidos e relativamente uniformes dentro de suas duas subordens, sendo suas características mais conspícuas as asas com cerdas e o aparato bucal adaptado a um hábito alimentar raspador-sugador (Triplehorn \& Johnson, 2005). Cerca de metade das espécies do grupo alimenta-se de fungos, enquanto a outra parte é composta por membros com hábito fitofágico com uma pequena parcela de predadores de pequenos artrópodes (Lewis, 1973). A classificação atual do grupo compreende duas subordens: Tubulifera, com apenas uma família (Phlaeothripidae) e Terebrantia, que possui 13 famílias, sendo cinco delas 
fósseis (Buckman, R. S., Mound, L. A., Whiting, M. F., 2013). Trabalhos sobre a organização morfofuncional do sistema digestivo em Thysanoptera são escassos na literatura, principalmente quando comparados a Hemiptera, devido, em parte, ao tamanho diminuto da vasta maioria das espécies. Um estudo realizado pelo nosso grupo de pesquisa com uma espécie do gênero Frankliniella sugere que os tripes possuam um complexo luminal de membranas do tipo MPM, o mesmo encontrado em Heteroptera (Ullman et al., 1989; Silva et al., 2004).

Muitas das espécies das ordens Hemiptera e Thysanoptera (reunidas no grupo Condylognatha) têm grande importância econômica. Os tripes, juntamente com os integrantes das subordens Sternorrhyncha e Auchenorrhyncha, contam com algumas das mais destrutivas pragas agrícolas, causando danos diretos (pela destruição dos tecidos vegetais como consequência da alimentação ou oviposição) ou indiretos (pela transmissão de patógenos) (Resh \& Cardé, 2003). Algumas espécies de hemípteros são responsáveis por extensos prejuízos à citricultura nacional por serem vetores da bactéria Xylella fastidiosa, causadora da clorose variegada dos citros (CVC) (De Nigri, 1990; Rossetti et al., 1990; Beretta et al., 1993; Donadio \& Moreira, 1997). O controle tradicional de pestes com inseticidas resultou no desenvolvimento de resistência em muitas delas. O manejo atual promove a adoção de alternativas para controlar estas pestes, como variedades de plantas resistentes e a utilização de parasitóides e patógenos como controle biológico (Resh \& Cardé, 2003). Alguns heterópteros são parasitas de vertebrados de sangue quente, incluindo o homem, sendo de grande importância para a saúde pública (Triplehorn \& Johnson, 2005). Dentro deste contexto, um estudo do sistema digestivo de insetos representantes do grupo Condylognatha reveste-se de grande interesse, dada a importância econômica e a escassez de trabalhos existentes na literatura acerca da sua morfofisiologia digestiva.

O presente trabalho é parte integrante de um amplo projeto conjunto de estudo da organização do processo digestivo nos insetos, num enfoque evolutivo, que está sendo realizado em uma colaboração entre o Laboratório de Bioquímica de Insetos, sob a coordenação do Prof. Dr. Walter Ribeiro Terra, 
do Departamento de Bioquímica do Instituto de Química da USP, e o Laboratório de Biologia Celular, do Departamento de Genética e Biologia Evolutiva do Instituto de Biociências da USP, dirigido pelo Prof. Dr. Alberto A. G. de Freitas Castro Ribeiro, no qual este trabalho de investigação foi desenvolvido. 
Objetivo 
Realizar um estudo comparativo da morfologia funcional do sistema digestivo de espécies representantes das ordens Hemiptera e Thysanoptera, do ponto de vista anatômico, histológico e ultraestrutural, em um enfoque evolutivo, com especial ênfase na organização do complexo luminal de membranas presente no intestino médio dessas espécies. 


\section{Material e Métodos}




\section{Material}

Em todos os experimentos realizados neste trabalho foram utilizados apenas indivíduos adultos, de ambos os sexos, das seguintes espécies:

1. Ordem Hemiptera

a. Subordem Auchenorrhyncha

i. Infraordem Cicadomorpha

1. Família Cicadellidae

\section{Espécie Dalbulus maidis}

2. Família Cercopidae

\section{Espécie Mahanarva fimbriolata}

ii. Infraordem Fulgoromorpha

1. Família Delphacidae

\section{Espécie Peregrinus maidis}

2. Ordem Thysanoptera

a. Subordem Terebrantia

1. Família Thripidae

\section{Espécie Frankliniella schultzei}

2. Família Aeolothripidae

Espécie Franklinothrips vespiformes

b. Subordem Tubulifera

1. Família Phlaeothripidae

\section{Espécie Liothrips sp.}

Os espécimes de $M$. fimbriolata foram coletados em plantações pertencentes à Empresa Brasileira de Pesquisa Agropecuária - EMBRAPA GADO DE CORTE em Campo Grande (MS). Indivíduos das espécies Dalbulus maidis e Peregrinus maidis foram gentilmente cedidos a partir de culturas mantidas no Laboratório de Insetos Vetores de Fitopatógenos (ESALQ - USP). Os espécimens da ordem Thysanoptera estudados neste trabalho foram coletados em campo, sendo que os indivíduos da espécie Frankliniella schultzei foram coletados no município de Araraquara (SP), enquanto que os espécimes de Liothrips sp. e Franklinothrips vespiformes foram encontrados, 
respectivamente, em Santo Antônio do Pinhal (SP) e em plantações na região de Campinas (SP)

\section{Métodos}

Todos os espécimes foram anestesiados sob gelo e dissecados sob microscópio estereoscópico Zeiss Stemi 2000-C, em solução fixadora apropriada para cada procedimento, e o sistema digestivo cuidadosamente isolado. No caso dos tripes, devido ao seu pequeno tamanho, a fixação do sistema digestivo foi realizada in situ com os espécimes imersos na solução fixadora in toto, retirando-se apenas a cabeça e a extremidade do abdômen para que o fixador pudesse penetrar a cavidade corporal e agir sobre o tubo digestivo.

\section{Anatomia}

O sistema digestivo dos animais foi dissecado e mantido em solução aquosa de $\mathrm{NaCl}$ 0,1 M para evitar o ressecamento. $O$ registro das imagens anatômicas foi feito por uma câmara digital Sony DSC-S75 Cyber-Shot, acoplada ao microscópio estereoscópico ou ao microscópio composto, ambos da Zeiss modelo Axioskop.

\section{Histologia}

Para os estudos histológicos, foi utilizado o fixador de Bouin (Beçak \& Paulete, 1976), que contém três partes de ácido pícrico, uma parte de formol a $37 \%$ e $5 \%$ de ácido acético. A fixação foi realizada por 12 horas a $4^{\circ} \mathrm{C}$.

Os tubos digestivos fixados foram desidratados em uma série de banhos sucessivos em álcool etílico 70 (15 minutos), 95 (15 minutos) e 100\% (duas séries de 20 minutos). Em seguida, procedeu-se à inclusão dos materiais em historesina da Leica, Heidelberg (hidroxietilmetacrilato), segundo 0 procedimento fornecido pelo fabricante. 
Após a polimerização da resina, os blocos foram cortados em micrótomo Leica RM 2145, utilizando-se de navalhas com fio de tungstênio. Os cortes obtidos entre 3 e $5 \mu \mathrm{m}$ de espessura, foram recolhidos em lâminas histológicas e colocados em placa aquecida a $45^{\circ} \mathrm{C}$ para secagem.

Para a coloração das preparações, os corantes foram previamente aquecidos em banho Maria a $45^{\circ} \mathrm{C}$ para aumentar a eficiência do processo. Os tecidos foram imersos em hematoxilina de Delafield por 10 minutos, lavados em água corrente, e, em seguida, imersos em eosina amarela por mais 30 segundos. Depois de corados, os cortes foram secos novamente em placa aquecida a $45^{\circ} \mathrm{C}$.

Para a montagem permanente das lâminas foi utilizado o meio de montagem Entellan (Merck, USA). O registro das observações histológicas foi feito por uma câmera digital Sony DSC-S75 Cyber-Shot, acoplada a um microscópio Zeiss, modelo Axioskop.

\section{Microscopia de Fluorescência Confocal}

Para verificar a possível presença da quitina no complexo luminal de membranas das espécies Mahanarva fimbriolata e Dalbulus maidis, as peças foram fixadas em solução de Zamboni (Stefanni et al., 1967), por 16 horas a $4^{\circ} \mathrm{C}$, e incluídas em parafina, seguindo um protocolo padrão de desidratação/inclusão (Beçak \& Paulete, 1976). Os cortes histológicos, na espessura de $12 \mu \mathrm{m}$, foram obtidos em um micrótomo Reichert-Jung modelo 820-II. Após desparafinização em xilol e a hidratação em série alcoólica decrescente, as lâminas com os cortes foram lavadas, primeiramente, em uma solução tampão de PBS (20 mM de tampão fosfato, $\mathrm{pH} 7,4$, contendo $0,15 \mathrm{M}$ de $\mathrm{NaCl}$ ) e em seguida com uma solução de $0,2 \%$ de Triton X-100 em PBS, por 1 hora à temperatura ambiente. A seguir, as preparações foram transferidas para uma câmara úmida e recobertas com uma solução do conjugado WGA-FITC (Wheat Germ Agglutinin-Fluorescein Isothiocyanate") diluído 1:500 em PBS na presença de 0,2M de $\mathrm{N}$-acetilglicosamina em tampão PBS, permanecendo nessa solução por um período de 18 horas, ao abrigo da luz, à temperatura de $4^{\circ} \mathrm{C}$. A ligação do WGA à quitina é específica na presença de excesso de $\mathrm{N}$ - 
acetilglicosamina (Peters \& Latka, 1986). Como controle, preparações foram incubadas apenas com PBS. Após o período de incubação, as lâminas foram lavadas em PBS, à temperatura ambiente, e montadas, com a utilização de VectaShield (Vector Labs, USA) como meio de montagem que retarda a perda de fluorescência das preparações. As preparações foram finalmente analisadas ao microscópio confocal Zeiss, modelo LSM-880. Para efeito de um controle mais rigoroso, o mesmo procedimento foi realizado com uma outra espécie de hemíptero, Dysdercus peruvianus (Heteroptera, Pyrrhocoridae).

\section{Ultraestrutura}

\section{Microscopia eletrônica de transmissão (MET)}

Para o estudo ultraestrutural, os tecidos foram fixados numa solução de glutaraldeído a $3 \%$ em tampão cacodilato de sódio $0,1 \mathrm{M}, \mathrm{pH} 7,4$, por duas horas a $4{ }^{\circ} \mathrm{C}$. Após a lavagem em tampão cacodilato de sódio com sacarose 0,2 M, o material foi pós-fixado em uma solução de tetróxido de ósmio $1 \% \mathrm{em}$ tampão cacodilato de sódio $0,1 \mathrm{M}$, também a $4{ }^{\circ} \mathrm{C}$, seguido por mais três banhos em solução salina de $\mathrm{NaCl} 0,1 \mathrm{M}$, a $4{ }^{\circ} \mathrm{C}$. Em seguida, as peças foram submetidas a uma contrastação em bloco ("en bloc" staining), com solução aquosa de acetato de uranila $1 \%$ por um período de 18 horas, a $4{ }^{\circ} \mathrm{C}$. As preparações foram, então, desidratadas em uma série de banhos sucessivos em soluções de álcool etílico 50, 70 e 95\% por 10 minutos cada e duas séries de 10 minutos em etanol $100 \%$, à temperatura ambiente. Para inclusão, foi utilizada o meio de Spurr (1969). A emblocagem final das peças foi feita em moldes de silicone e a polimerização da resina obtida em estufa a $56{ }^{\circ} \mathrm{C}$, por 72 horas. Os cortes ultrafinos foram obtidos em um ultramicrótomo Leica Ultracut UCT, recolhidos em telas de cobre de 200 mesh, previamente recobertas com um filme de parlódio e carbono. Em seguida, os cortes foram contrastados em uma solução de citrato de chumbo (Reynolds, 1963) e analisados ao microscópio eletrônico de transmissão Zeiss, modelo EM-900, operado a 80 $\mathrm{kV}$. 
Além da metodologia acima descrita, foi utilizado o procedimento de fixação alternativo, denominado de fixação-dupla, que consiste na fixação do material em uma solução contendo glutaraldeído $2 \%$ e tetróxido de ósmio $1 \%$ em tampão cacodilato de sódio $0,1 \mathrm{M}, \mathrm{pH} 7,4$, por 1 hora sob gelo. Após a fixação, as peças passaram por três banhos sucessivos em solução salina de $\mathrm{NaCl} 0,1 \mathrm{M}$, a $4^{\circ} \mathrm{C}$, continuando então com o procedimento como acima descrito.

\section{Microscopia Eletrônica de Varredura (MEV)}

Para os estudos em microscopia eletrônica de varredura, foram utilizados apenas as regiões referentes ao intestino médio do sistema digestivo das espécies $D$. maidis e $M$. fimbriolata, com foco principal na região anatômica denominada de domínio cônico, devido às suas maiores dimensões e facilidade na manipulação. As peças anatômicas foram fixadas em solução de glutaraldeído a 3\% em tampão cacodilato de sódio, seguido por três banhos em tampão cacodilato $0,2 \mathrm{M}$ e pH 7,4. A seguir, o material passou por um banho em ósmio $1 \%$ por 1 hora, outro em ácido tânico $1 \%$ por 10 minutos retornando ao ósmio $1 \%$ por mais 30 minutos. As peças foram, então, lavadas três vezes em água destilada por 5 minutos cada.

O procedimento de desidratação adotado é similar ao utilizado para a microscopia eletrônica de transmissão, descrita anteriormente. Após a bateria de banhos em concentrações crescentes de etanol, os materiais passaram pelo procedimento de secagem em ponto crítico de $\mathrm{CO}_{2}$ no equipamento Balzers, modelo CPD-030.

Finalmente, as preparações foram montadas em suportes adequados para as amostras (stubs), recobertos por uma camada de ouro em um metalizador Balzers, modelo SCD-050 e examinadas ao microscópio eletrônico de varredura Zeiss, modelo DSM-940.

Além da metodologia descrita acima, parte do material foi preparado segundo uma modificação da técnica descrita por Armstrong \& Parenti (1973). Nesta técnica, as peças foram fixadas com fixador de Bouin por 24 horas, a temperatura ambiente, foram desidratadas em solução crescente de etanol, 
como citado anteriormente e, em seguida, colocadas em contato com a solução de álcool mais xilol, na proporção de volume 1:1, por uma hora a temperatura ambiente. Após esse período, os materiais passaram por banho de xilol de duas horas e foram transferidas para recipientes contendo parafina dentro de uma estufa a $58{ }^{\circ} \mathrm{C}$, temperatura do ponto de fusão da parafina. Depois de duas horas as peças foram transferidas para moldes apropriados e deixados a temperatura ambiente até o dia seguinte. A partir dos blocos de parafina foram obtidos alguns cortes de $5 \mu \mathrm{m}$ de espessura em micrótomo Leica RM 2145, que foram, então, corados pelos corantes Hematoxilina-Eosina. O restante do material foi transferido para um recipiente contendo xilol e ali permaneceu até a remoção total da parafina. Em seguida os materiais foram colocados em contato com álcool $100 \%$ e preparados para serem observados no microscópio eletrônico de varredura, como foi descrito acima. 
Resultados 


\section{Hemiptera}

\section{Mahanarva fimbriolata}

Os espécimes de $M$. fimbriolata possuem tamanho médio de $13 \mathrm{~mm}$ de comprimento. Anatomicamente, o sistema digestivo da espécie tem início na boca e segue pelo esôfago (E), caracterizado como um tubo curto e indiferenciado que culmina na câmara de filtração (CF). Conforme mencionado anteriormente, a CF consiste na associação de segmentos do intestino médio anterior, posterior e das regiões proximais dos quatro túbulos de Malpighi. $O$ intestino médio inicia-se ainda dentro da CF e, ao sair dela, diferencia-se em dois domínios, o cônico e o tubular. O domínio cônico (DC) é uma região expandida do intestino médio, que uma superfície com aparência enrugada. Após essa região expandida, o intestino médio continua como um tubo longo, simples e delgado, denominado domínio tubular (DT), que forma uma alça, retornando à CF. A transição do intestino médio para o posterior ocorre em uma região denominada piloro, no interior da CF. O sistema digestivo segue externamente à CF pelo intestino posterior (IP), caracterizado por um tubo delgado e levemente achatado que leva ao reto e, posteriormente, ao ânus. Observam-se, ainda, quatro túbulos de Malpighi (TM), órgãos do sistema excretor, que emergem da CF em direção ao reto, enovelando-se ao redor da câmara em direção ao reto. Os TM de $M$. fimbriolata apresentam-se indiferenciados em toda sua extensão (Figura 1).

Após o curto intestino anterior, de difícil visualização após dissecção, observa-se a câmara de filtração que, histologicamente, apresenta uma organização complexa em razão da aposição dos tecidos do intestino médio posterior e Malpighi, como descrito anteriormente. Esses epitélios incluem porções do intestino médio anterior e posterior, além do piloro e as regiões proximais dos TM, tornando difícil a identificação das células de cada tecido (Figura 2A). As células predominantes nessa região são pavimentosas, delgadas e com citoplasma bastante reduzido. Essa organização é importante para o transporte de água realizado pela CF, como já discutido. 
O IM é dividido em dois domínios. O DC é um tubo expandido formado por células cúbicas e possui núcleos relativamente grandes e com formato bastante irregular devido às invaginações do epitélio. As células dessa região possuem borda em escova desenvolvida, bem evidenciada nos cortes histológicos (Figura 2B).

O DT possui células com características semelhantes ao DC, sendo relativamente maiores e dispostas de maneira irregular. Seus núcleos são grandes, de aspecto granuloso e localizam-se em diferentes regiões das células. A luz do tubo é facilmente visualizada e é possível verificar a presença de um conteúdo luminal nesse domínio (Figura $2 \mathrm{C}$ ).

O IP é composto por células menores, com núcleos pequenos e arredondados, quando comparados às outras regiões do sistema digestivo dos animais. Essas células se encontram regularmente justapostas e são recobertas por uma camada de quitina. A transição para o intestino posterior, o piloro, é levemente expandida e possui as mesmas características descritas acima. $O$ epitélio do IP possui grande afinidade pela hematoxilina utilizada como corante, o que indica a presença de estruturas de característica basófila nas células dessa região (Figura 2D).

Conforme mencionado anteriormente, a CF se apresenta como uma aposição de tecidos que dificulta, do ponto de vista ultraestrutural, a identificação dos diferentes tipos celulares presentes na região. De modo geral, a CF de $M$. fimbriolata apresenta células alongadas, com núcleos relativamente grandes e limites intercelulares de difícil visualização. A membrana plasmática apical destas células é modificada em numerosas microvilosidades que se projetam ao lúmen. A membrana plasmática basal dessas células apresenta inúmeras invaginações, que formam um padrão tubular no citosol. É bastante evidente a presença de um segundo tipo celular no interior da CF, que corresponde às regiões proximais dos TM. As células dos TM são achatadas, com citoplasma reduzido e mitocôndrias presentes por toda a extensão da célula (Figura 3B). Essas células são repletas de invaginações da membrana plasmática basal e são facilmente identificáveis pelo padrão lamelar formado pelas invaginações, que diferem do tubular observado nas células do intestino (Figura 3). 
O restante do IM fora da CF apresenta, essencialmente, dois tipos celulares: os enterócitos e as células regenerativas. Os enterócitos possuem citoplasma reduzido, grande número de mitocôndrias, principalmente na região apical das células, vesículas de secreção conspícuas e dispersas no citoplasma. Organelas da rota secretora, como áreas de Golgi e elementos do retículo endoplasmático rugoso são abundantes e são mais frequentemente encontradas em regiões próximas ao núcleo (Figura 4). A região basal dessas células encontra-se modificada, apresentando invaginações da membrana plasmática basal que formam um sistema de canais associados a mitocôndrias com algumas poucas aberturas em direção à lâmina basal (Figura 3). A característica mais marcante da célula é, porém, a diferenciação da membrana plasmática apical em microvilosidades, presentes em grande número e dispostas paralelamente umas às outras por toda a extensão apical das células (Figura 3Figura 4). No interior destas estruturas, é possível observar filamentos de actina dispostos em feixes longitudinais, que se prolongam para o interior da célula e compõem a trama terminal. Associada à superfície extracelular das microvilosidades, há um material granuloso que corresponde, provavelmente, ao glicocálix (Tsai e Perrier, 1996). As células regenerativas são pouco numerosas e se localizam à base do epitélio, apresentando núcleo relativamente grande com relação ao seu citoplasma.

Associado às microvilosidades dos enterócitos de $M$. fimbriolata é possível observar a presença de um complexo luminal de membranas que parece se originar das extremidades das microvilosidades e que se prolongam em direção à luz do intestino médio (Figura 1), formando folhetos membranosos semelhantes a pequenas chamas (Figura 5). As microvilosidades também se associam às vesículas presentes na região.

As imagens obtidas através de MEV mostram uma superfície epitelial irregular formada por uma série de projeções que correspondem aos enterócitos. Assim, cada enterócito apresenta uma superfície apical expandida e uma baso lateral mais estreita, na forma de um cogumelo (Figura 6A). O DT, por sua vez, se apresenta com um padrão semelhante. Por outro lado, em preparações realizadas com uma pré-inclusão em parafina antes do procedimento para MEV, observa-se uma melhor preservação do epitélio do IM 
e, com isso, foi possível a observação de uma película delicada formada por um folheto membranoso que, aparentemente, reveste todo o epitélio. Em algumas regiões notam-se rupturas nesta película (possivelmente devido à manipulação das amostras), que possibilitam a observação das microvilosidades dos enterócitos logo abaixo do folheto membranoso. Além disso, observa-se também a presença de uma grande quantidade de vesículas de diferentes tamanhos associadas às microvilosidades (Figura 6).

\section{Dalbulus maidis}

A cigarrinha $D$. maidis apresenta-se com comprimento médio de $4 \mathrm{~mm}$, alimenta-se majoritariamente de floema e seu sistema digestivo apresenta 0 mesmo padrão anatômico encontrado em $M$. fimbriolata. Observa-se um intestino anterior curto e indiferenciado conectando a boca à $C F$, seguido por um intestino médio anatomicamente dividido nos $D C$ e DT, retornando à CF. $O$ intestino posterior tem início no piloro, ainda na CF e continua externamente à câmara em direção à região posterior do inseto. O IP termina em uma pequena dilatação, o reto, antes de dar origem ao ânus. Os TM de $D$. maidis emergem da CF e suas extremidades distais se associam ao reto, de modo semelhante ao observado em M. fimbriolata. Entretanto, no cicadelídeo, observam-se dilatações de coloração branco leitosa próximas às suas extremidades distais (Figura 8).

Os tecidos observados na região da CF apresentam células com núcleos relativamente grandes e bastante delgadas, sendo pouco visível a divisão intercelular. É possível observar, também, as regiões proximais dos TM circundando o órgão (Figura 9).

O DC tem origem ainda dentro da câmara de filtração e prolonga-se a partir dela como um tubo expandido com invaginações sutis no epitélio. O DC é composto por células delgadas, com formato irregular e núcleos relativamente grandes que acompanham o formato das células. O segundo domínio do intestino médio é o DT que possui características semelhantes às do DC. O DT tem origem ao final do domínio cônico e término dentro da CF, onde se encontra a região de transição para o intestino posterior, o piloro. O DT possui 
células com citoplasma de aspecto granuloso e núcleos relativamente maiores que os do DC (Figura 9).

Os túbulos de Malpighi (TM) podem ser encontrados integrando a câmara de filtração, enovelando-se por todo o órgão e, também, prolongandose a partir dele em formato tubular. Como já mencionado anteriormente, os TM de Dalbulus maidis são diferenciados em três regiões: região proximal, expandida e distal. A região expandida diferencia-se histologicamente das porções proximais e distais dos TM (Figura 9C). A porção proximal dos TM saem da CF como túbulos estreitos que possuem células achatadas com núcleos arredondados e pouco citoplasma. Ao atingir a porção central, as células se tornam dilatadas, com um grande número de vesículas, e a luz do tubo aumenta relativamente de diâmetro. As células da região distal voltam a ser semelhantes às da porção proximal ao se aproximarem do intestino posterior.

As análises ultraestruturais nos permitem observar que os enterócitos do IM são similares ao descrito para M. fimbriolata, com microvilosidades apicais, invaginações da membrana plasmática basal, núcleos relativamente grandes, numerosas áreas de Golgi, vesículas de secreção, e elementos do retículo endoplasmático rugoso, além da grande quantidade de mitocôndrias próximas à região apical da célula. Ao observar o lúmen da região, é possível verificar que as microvilosidades sofrem constrições apicais, formando pequenas vesículas que mantém sua associação com a membrana microvilar (Figura 10). Essas vesículas projetam-se em direção ao lúmen, aparentemente se alongando até formarem estruturas cilíndricas e cisternais limitadas por membranas simples. Estas membranas formam, aparentemente, uma cobertura contínua sobre as microvilosidades que pode ser observada ao longo de toda a luz do intestino médio, sempre em associação com a face apical do epitélio (Figura 13).

Nas imagens obtidas por MEV de espécimes de D. maidis o DC se apresenta com um epitélio espesso, que forma invaginações na luz do tubo. Ao contrário do observado em $M$. fimbriolata os enterócitos dessa espécie parecem ter a região apical mais estreita que a basal, formando o padrão observado (Figura 11). Com o epitélio sendo mais espesso, há uma redução do 
espaço luminal condizente com as análises histológicas (Figura 11B e C). Novamente, não é possível observar os ápices das Microvilosidades nessas preparações devido a presença de um revestimento membranoso que se estende por todo o DC (Figura 11D). Assim como ocorre em M. fimbriolata é possível observar, em algumas regiões, rupturas nesse revestimento, possibilitando a visualização das microvilosidades e vesículas associadas. Essa organização é condizente com a observada por MET.

É possível também observar um dos TM de $D$. maidis próximo ao DC. Nota-se que o epitélio dessa região é estreito, com células de citoplasma reduzido, com microvilosidades na região apical e, na região mediana, a presença de uma grande quantidade de estruturas estreladas denominadas de brocossomos (Figura 12). As regiões proximal e distal não apresentam brocossomos na luz do tubo.

\section{Peregrinus maidis}

Diferentemente das espécies de cigarrinhas já descritas, o hemíptero $P$. maidis é integrante da infraordem Fulgoromorpha, família Delphacidae. A espécie se alimenta de fluidos vegetais de diversas plantas e apresentam um comprimento médio de 2,5 mm. Seu sistema digestivo tem início na boca, onde se encontra um par de glândulas salivares (GS), sendo uma glândula principal e uma acessória. O ducto proveniente da glândula principal une-se ao da glândula acessória para formar o ducto salivar comum, que termina no canal salivar, no estilete. $O$ intestino anterior tem início na base do estilete maxilar, com o precibarium, seguido pelo cibarium e, então, pelo esôfago (E). O E se apresenta como um tubo estreito que se estende à região anterior do abdômen, desembocando no intestino médio (IM), onde apresenta uma pequena constrição, que sugere a presença de uma válvula esofageal, de difícil visualização (Tsai \& Perrier, 1993). Estendendo-se paralelamente ao $\mathrm{E}$ observa-se um saco em fundo cego que se estende do IM em direção à cabeça do animal, o ceco gástrico. O IM é composto por um tubo longo e contorcido, sem diferenciações anatômicas evidentes, que se comunica com um reto. $O$ sistema digestivo de $P$. maidis não possui uma CF como nas espécies 
analisadas até o momento, mas nota-se que as regiões anterior e posterior do IM estão em íntimo contato. Os espécimes de $P$. maidis apresentam uma pequena dilatação ao final do IM de onde se projetam dois pares de túbulos de Malpighi (Figura 16). Cada par de TM apresenta-se fundido, separando-se apenas na região distal, formando uma forquilha que segue em direção ao ânus (Tsai \& Perrier, 1993). Devido ao reduzido número de exemplares que foi possível obter das culturas dessa espécie, não foi realizado um estudo histológico de seu sistema digestivo, optando-se por priorizar uma análise ultraestrutural.

Sob o ponto de vista ultraestrutural, os enterócitos do intestino médio de $P$. maidis também apresentam organização distinta da observada nas duas cigarrinhas descritas previamente. Suas microvilosidades são relativamente mais longas e estreitas do que as observadas em $D$. maidis e $M$. fimbriolata. Além disso, a membrana plasmática basal desses enterócitos não possuem tantas invaginações, com raras aberturas em direção à lâmina basal (Figura 17). O complexo luminal de membranas observado em $P$. maidis encontra-se disposto em camadas, formando uma cobertura espessa, com alta eletrondensidade, próxima ao ápice das microvilosidades (Figura 19). É possível observar a presença de múltiplas vesículas em ambos os lados dessa cobertura, entre as microvilosidades e na região do lúmen (Figura 18).

\section{Visualização do CLM por Microscopia de Fluorescência Confocal}

Nas preparações de cortes histológicos do intestino médio para microscopia confocal de $M$. fimbriolata e $D$. maidis incluídos em parafina e incubados com conjugado de WGA-fluoresceína, na presença de excesso de $\mathrm{N}$-acetilglicosamina, verifica-se a ocorrência de uma estrutura intensamente fluorescente ao longo de todo o intestino, correspondente ao complexo luminal de membranas (Figura 14 eFigura 15). Nas preparações usadas como controle sem o conjugado, a fluorescência é insignificante, indicando, assim, a presença de quitina nessas estruturas luminais. As preparações-controle adicionais realizadas com intestino de $D$. peruvianus também não exibiram uma fluorescência significativa. 


\section{Thysanoptera}

Devido ao reduzido tamanho dos indivíduos das espécies estudadas dessa ordem (Figura 20), foi realizado apenas um estudo geral anatômico "in situ" do sistema digestivo através de cortes semi-finos realizados para MET (Figura 21). A prioridade foi dada, portanto, para a análise ultraestrutural por MET.

\section{Frankliniella schultzei}

Os espécimes de $F$. schultzei se apresentam com comprimento médio de $1,2 \mathrm{~mm}$ e seu sistema digestivo é anatomicamente semelhante aos descritos para outras espécies da subordem Terebrantia (cf. Ullman et al., 1989). Alimentam-se através da sucção de tecidos vegetais. O intestino anterior tem início no esôfago, que se apresenta como um tubo indiferenciado e que se alonga até o início do intestino médio (IM). O sistema digestivo segue então para o IM, que se apresenta como um tubo alongado que forma três voltas no corpo do animal, podendo ser denominadas IM anterior, médio e posterior (IMa, IMm e IMp, respectivamente). Apesar das três regiões apresentarem-se indiferenciadas externamente, apresentam diferenças a nível ultraestrutural. Os enterócitos do IMa e IMp possuem abundância de organelas relacionadas a rota secretora, como áreas de Golgi e elementos do retículo endoplasmático rugoso, além de uma grande quantidade de mitocôndrias que se concentram no citoplasma apical. As microvilosidades desses enterócitos possuem aspecto e comprimento uniforme, com baixa densidade eletrônica e apresentam-se justapostas. Do ápice das microvilosidades é possível observar membranas associadas, que projetam-se ao lúmen do intestino médio e parecem conectar-se umas às outras (Figura 23), parecendo revestir grupos de microvilosidades e formando dois compartimentos distintos, sendo o mais próximo ao ápice celular o mais eletrondenso (Figura 22). Os enterócitos do IMm diferem dos acima descritos pois não apresentam organelas relacionadas a rota secretora tão abundantes. O IM segue então para a região posterior do corpo do animal, terminando no ânus. 


\section{Franklinothrips vespiformes}

Os espécimes de $F$. vespiformes possuem comprimento médio de $2 \mathrm{~mm}$. Ao contrário das demais espécies estudadas, esta é a única espécie no presente projeto a apresentar um hábito alimentar predatório, uma vez que esta espécie alimenta-se de pequenos artrópodes.

F. vespiformes exibe o mesmo padrão anatômico descrito para os outros membros da subordem Terebrantia. O sistema digestivo tem início na boca e segue pelo esôfago até o intestino médio. O IM consiste em um tubo alongado, indiferenciado anatomicamente, com três domínios distintos (IMa, IMm e IMp) que se estende até o ânus.

Os enterócitos do intestino médio de $F$. vespiformes exibem uma abundância de vesículas, especialmente no citoplasma apical e no lúmen junto às microvilosidades. Observa-se também que a espécie possui microvilosidades mais curtas no intestino médio, quando comparadas à espécies acima descritas, sendo que as membranas associadas aos ápices das microvilosidades aparentemente englobam grupos de número variável de microvilosidades (Figura 25), como descrito por Del Bene (1991). Entretanto, tais membranas não revestem as microvilosidades individualmente, como no modelo MPM, indicando a existência de um arranjo diverso de complexo luminal, mais próximo a um modelo MLC (Figura 24).

\section{Liothrips sp.}

Os indivíduos deste gênero, em geral fungívoros, possuem cerca de 2 $\mathrm{mm}$ de comprimento e a anatomia de seu sistema digestivo segue o padrão geral observado em integrantes da subordem Terebrantia, descrita acima.

Do ponto de vista da ultraestrutura, os enterócitos de Liothrips $s p$. exibem algumas similaridades com as observadas nas espécies anteriores, como grande quantidade de mitocôndrias associadas à base das microvilosidades, citoplasma reduzido com núcleos relativamente grandes e uma abundância de vesículas dispersas no citosol e associadas às microvilosidades. Entretanto, uma análise mais detalhada revelou a ocorrência 
de um grande número de vesículas no interior das microvilosidades dos enterócitos do IMa (Figura 26). Além disso, as microvilosidades dessa região apresentam uma disposição irregular, compactamente dispostas, sendo que seus ápices parecem estar conectados por membranas formando uma espécie de barreira para o lúmen (Figura 27 e Figura 28). Os enterócitos observados no IMp, por sua vez, exibem microvilosidades que se dispõem de forma distinta da descrita acima. Tais estruturas são relativamente mais longas, retilíneas e com espaçamento regular entre elas. É possível a observação de algumas poucas membranas que se projetam na luz do intestino, sem formar, entretanto, um complexo luminal elaborado (Figura 29). Uma característica importante dessa região é a existência de um glicocálix bastante desenvolvido que reveste as microvilosidades. Em cortes longitudinais das microvilosidades é possível notar a presença de pequenas trabéculas, regularmente espaçadas, ao longo de seu comprimento, também evidenciadas em cortes transversais (Figura 30 e Figura 31). 


\section{Discussão}


O presente projeto teve início com uma análise anatômica, histológica e ultraestrutural do sistema digestivo dos hemípteros Dalbulus maidis e Mahanarva fimbriolata, com o objetivo não só de identificar os diferentes tipos celulares que compõem o epitélio intestinal, mas, principalmente, de averiguar a presença e o tipo de organização do complexo luminal de membranas no intestino médio destes insetos. Estes estudos revelaram que ambas as espécies possuem um complexo luminal semelhante ao descrito por Utiyama (2011) e Utiyama et al., (2017) para a cigarrinha Bucephalogonia xanthophis (Hemiptera: Cicadellidae), denominado de membranas luminais em forma de chama (MLC). Estes resultados foram surpreendentes, pois confirmaram a existência de um modelo de organização do complexo luminal de membranas em Hemiptera distinto do tradicionalmente descrito na literatura, conhecido como modelo de membranas perimicrovilares (e perimicrovilares modificadas). Esta fase inicial foi continuada por um detalhamento maior da organização ultraestrutural do intestino médio de $D$. maidis e $M$. fimbriolata (infraordem Cicadomorpha), incorporando ainda o estudo de uma espécie pertencente a outro grupo de Cicadomorpha, a infraordem Fulgoromorpha (Peregrinus maidis). Este tipo de abordagem possibilitou uma visão mais abrangente sobre a organização do sistema digestivo dos Hemiptera, revelando a grande diversidade morfológica existente, em particular com relação ao complexo luminal de membranas. Este projeto de investigação do sistema digestivo dos Hemiptera foi significativamente ampliado com a introdução do estudo de espécies pertencentes a ordem Thysanoptera, filogeneticamente relacionada aos Hemiptera, cujo conhecimento da organização do sistema digestivo é ainda mais escasso. Nas três espécies analisadas ( $F$. shultzei, F. vespiformes e Liothrips sp.) um elaborado complexo luminal de membranas foi detectado, diverso, mais uma vez, do modelo clássico de membranas perimicrovilares citado na literatura. Estes resultados indicam que a enorme diversidade na organização do sistema digestivo, em especial do complexo luminal de membranas, não se restringe apenas aos Hemiptera, mas inclui os Thysanoptera, uma outra ordem pertencente aos Condylognatha.

Do ponto de vista anatômico, o sistema digestivo das três espécies da ordem Hemiptera estudadas no presente projeto apresentam semelhanças 
morfológicas, exibindo estruturas anatomicamente complexas, compatíveis com o encontrado na literatura (cf. Wigglesworth, 1972; Terra, 1988; Chapman, 1998). As espécies mais similares entre si são as pertencentes à infraordem Cicadormorpha, Dalbulus maidis e Mahanarva fimbriolata, que apresentam especializações adaptativas características de insetos sugadores de seiva. Seu sistema digestivo consiste em intestino anterior indiferenciado, o esôfago, uma câmara de filtração, intestino médio anatomicamente diferenciado em dois domínios, piloro, intestino posterior, reto e ânus, além dos quatro túbulos de Malpighi (TM). Apesar de fazerem parte do sistema excretor, os TM também exercem funções importantes na digestão desses animais, ao concentrar os nutrientes no início do intestino médio no interior da CF, como será discutido mais adiante.

O IA da maioria dos insetos pode ser diferenciado em faringe (imediatamente após a boca), esôfago (tubo delgado e indiferenciado), papo ou proventrículo (região expandida ao final do intestino anterior) e terminar com a presença de uma válvula esofageal que regula a passagem do alimento para o IM (Triplehorn \& Johnson, 2005). As espécies D. maidis e M. fimbriolata não apresentam tais modificações, de forma que seu IA consiste no esôfago, um tubo simples, formado por um epitélio pavimentoso e recoberto internamente por uma fina camada de quitina, que conecta a boca à CF.

A CF é uma especialização do canal alimentar que conecta duas regiões, normalmente distantes, do tubo digestivo (Triplehorn \& Johnson, 2005). Esse órgão, típico de insetos sugadores da infraordem Cicadomorpha (Resh \& Cardé, 2003) consiste na associação de segmentos do intestino médio anterior, intestino médio posterior e das regiões proximais dos quatro TM. Nesta região, o epitélio dos tecidos associados é menos espesso, formado por células com citoplasma bastante reduzido e com invaginações da membrana plasmática basal bem desenvolvidas, que facilitam o transporte de água diretamente do início do IM para o IP através dos TM, resultando numa maior concentração de nutrientes (Cheung \& Marshall, 1973a, b; Marshall \& Cheung, 1974). Essa especialização é fundamental para esses animais, uma vez que a seiva das plantas, tanto o xilema quanto o floema, é uma fonte nutricional bastante desbalanceada. $\mathrm{O}$ xilema é pobre em aminoácidos, contém 
monossacarídeos, ácidos orgânicos, íons potássio e outros minerais também em baixas concentrações, sendo, portanto, um alimento extremamente diluído. O floema é, também, pobre em aminoácidos, mas possui alta concentração de sacarose (Terra, 1988; Terra et al., 1996a; b). Insetos sugadores de xilema, como a cigarrinha $M$. fimbriolata, ou de floema, como a $D$. maidis, precisam concentrar os nutrientes orgânicos de modo a aumentar a eficiência de absorção destes componentes (Gouranton, 1968; Cheung \& Marshall, 1973a; b; Terra, 1988). A CF pode chegar a concentrar o xilema em até 10 vezes (Cheung \& Marshall, 1973a; b) e o floema em 2,5 vezes (Lindsay \& Marshall, 1980).

No caso dos hemípteros que se alimentam de floema, como a cigarrinha D.maidis, a CF pode atuar de outro modo. O floema apresenta altas concentrações de sacarose, sendo hiperosmótico com relação à hemolinfa. De fato, a concentração de carboidratos pode chegar a 1,0 M, que corresponde a quatro ou cinco vezes a concentração da hemolinfa (Ashford et al., 2000; Fisher, 2000; Douglas, 2006). Neste contexto, a CF atuaria como um dos mecanismos de combate ao estresse osmótico imposto pelo floema, permitindo o transporte de água a partir da região posterior do IM para a porção anterior, diluindo o conteúdo luminal do intestino (Rhodes et al., 1997; Douglas, 2003; Shakesby et al., 2009).

Ainda dentro da CF temos a região de transição do IM para o IP denominada piloro, na qual se inserem as regiões proximais dos quatro TM. $O$ IP é caracterizado por um tubo longo e achatado, que se diferencia em um reto e termina no ânus. $O$ epitélio desta porção do tubo digestivo é composto por células achatadas e revestidas por uma camada de quitina.

Apesar do inseto $P$. maidis apresentar modificações ao longo do seu intestino anterior (IA), a espécie exibe um sistema digestivo menos elaborado morfologicamente, quando comparado aos demais exemplares da subordem Auchenorrhyncha. Seu IA tem início na base do estilete maxilar e é diferenciado em precibarium, cibarium e esôfago, além de exibir um par de glândulas salivares e um ceco gástrico. O esôfago, por sua vez, apresenta uma pequena constrição no local de transição para o IM que pode indicar a 
presença de uma válvula esofageal. A presença dessa válvula, ausente nos exemplares de Cicadomorpha, pode indicar um controle na passagem do alimento do IA para o IM. Paralelamente ao esôfago, estendendo-se do IM em direção à cabeça do animal, encontra-se uma estrutura tubular, alongada e de fundo cego, denominada divertículo ou ceco gástrico (Ammar, 1986). Essa estrutura normalmente apresenta uma pequena constrição na transição para o IM que pode funcionar como um esfíncter (cf. Ammar, 1986; Tsai \& Perrier, 1993). O IM consiste em um tubo longo, indiferenciado, onde, apesar da ausência de uma CF, observa-se um contato entre suas porções anterior e posterior pela curvatura do próprio tubo, sugerindo a possibilidade de ocorrência de outro tipo de mecanismo de concentração ou diluição de nutrientes (Goodchild, 1966), análogo ao que ocorre na CF.

Os TM de algumas espécies da subordem Auchenorrhyncha podem apresentar uma região expandida adaptada para a produção e secreção de estruturas estreladas conhecidas por brocossomos (Raikitov, 1995; Utiyama, 2011; Utiyama et al., 2017). Estas estruturas são constituídas por lipídios e proteínas em um arranjo regular que são liberadas pelos TM no IP e excretadas. Após serem eliminados pelo ânus, os brocossomos são coletados pelas patas traseiras e espalhados sobre $o$ tegumento, impermeabilizando 0 corpo do inseto. Os TM das três espécies de Hemiptera estudadas são morfologicamente diferentes entre si. A cigarrinha $D$. maidis é a única representante analisada que exibe tal especialização relacionada à produção de broncossomos. Seus TM podem ser anatomicamente diferenciados em três regiões: proximal, secretora e distal. A porção secretora, expandida e com aspecto branco leitoso, é a responsável pela produção e secreção dos brocossomos. Por outro lado, os quatro TM de $M$. fimbriolata são indiferenciados em toda sua extensão. Já os TM do Fulgoromorpha $P$. maidis se apresentam como dois pares fundidos na região proximal, que se separam no último terço do comprimento, formando uma bifurcação na região distal em direção ao ânus (cf. Ammar, 1986; Tsai \& Perrier, 1993).

O estudo ultraestrutural do IM do sistema digestivo das espécies representantes da ordem Hemiptera revelou resultados bastante significativos 
que permitem aclarar alguns aspectos ainda desconhecidos da organização da digestão nesses insetos.

O DC e o DT de M. fimbriolata apresentam um complexo luminal de membranas similar ao descrito por Utiyama et al., (2017) para B. xanthophis, denominado de membranas luminais em forma de chama (MLC). Este tipo de complexo luminal de membranas é formado, aparentemente, a partir da vesiculação das microvilosidades dos enterócitos, que se mantêm associadas ao ápice das microvilosidades. Estas vesículas se alongam e se fundem, formando um sistema de membranas que se projetam à luz do intestino e delimitam um aparentemente fechado, como indicado por um estudo de difusão de um traçador luminal (Utiyama et al., 2017). Quando comparadas a outras espécies estudadas de Cicadellidae, as MLC de $M$. fimbriolata parecem ser menos desenvolvidas (Utiyama, 2011; 2016; Utiyama et al., 2017). Esta diferença pode estar correlacionada com a complexidade anatômica da CF, uma vez que tanto a câmara, quanto as MLC devem ter sido selecionadas conjuntamente para um aumento global na eficiência do processo digestivo (Utiyama, 2016). Assim, quanto mais complexa a CF, mais eficiente seria a concentração dos nutrientes na porção média do IM, facilitando sua absorção e tornando o papel das MLC menos relevante, resultando em sua redução ao longo da evolução.

As imagens obtidas através de MEV dão suporte às observações ultraestruturais de MET, mostrando células do epitélio colunar de DC e DT formando uma série de dobramentos. As observações sugerem que cada enterócito apresenta uma superfície apical expandida e uma basolateral mais estreita, assemelhando-se a um cogumelo. Um resultado importante foi a constatação da existência de uma película membranosa muito delicada revestindo o ápice das MLC ao longo do IM, sugerindo a existência de uma possível barreira entre o epitélio e a luz intestinal. A presença de numerosas vesículas entre as microvilosidades e nas MLC não tem uma função determinada, mas devem estar relacionadas à própria formação do complexo luminal ou comprometidas com o transporte de enzimas digestivas. 
Por outro lado, a análise ultraestrutural detalhada do intestino médio de D. maidis realizada neste trabalho corroboram os dados preliminares obtidos anteriormente (Utiyama, 2016), indicando a presença de um complexo luminal de membranas também do tipo MLC e que sua origem celular seja a mesma descrita acima para $M$. fimbriolata. A presença de uma película contínua, similar à detectada nesta última espécie, revestindo a face luminal da MLC, foi igualmente notada em preparações para MEV de $D$. maidis.

A análise dos resultados obtidos por MEV de D. maidis indica grande correspondência com o estudo histológico do IM da espécie. O DC se apresenta como um tubo expandido, com um epitélio espesso, formado por uma única camada de células colunares (enterócitos) e com espaço luminal reduzido. Esse epitélio apresenta uma série de dobras, formando invaginações estreitas na luz do tubo. Uma análise mais detalhada das imagens obtidas por MET sugerem que as MLC de $D$. maidis originem estruturas semelhantes a cisternas, que delimitam compartimentos luminais fechados. Tais estruturas parecem recobrir toda a superfície dos enterócitos e impedem a visualização das microvilosidades em preparações para MEV. Em algumas regiões das amostras, foram encontradas rupturas na estrutura que reveste o epitélio e isso permitiu a observação das microvilosidades e vesículas associadas. Além disso, a medição da espessura deste revestimento em regiões de fratura das preparações previamente incluídas em parafina, mostrou que suas dimensões são compatíveis com a de uma membrana simples. Assim, estes resultados indicam que esse revestimento seja de fato formado pela fusão das membranas e vesículas associadas às microvilosidades, como sugerido pelas análises a partir de MET.

As superfícies apicais dos enterócitos possuem aspecto uniforme, mas quando observadas em detalhe, pode-se notar que são repletas de pequenas estruturas vesiculares de tamanhos e formatos variáveis associadas à MLC, semelhantes às observadas em $M$. fimbriolata. Ao comparar os tamanhos das vesículas, foi constatado que as observadas por MEV sobre os enterócitos são entre 8 a 10 vezes maiores do que as descritas nas imagens de MET e, portanto, tratam-se de estruturas diferentes. A função destas vesículas ainda não é clara, mas do mesmo modo que em $M$. fimbriolata, pode estar 
relacionada à formação do próprio complexo e/ou à secreção de enzimas digestivas.

Nas imagens obtidas por MEV, também foi possível observar alguns brocossomos concentrados no lúmen de um TM. Como mencionado anteriormente, os TM de $D$. maidis são divididos em três domínios distintos que possuem diferenças morfológicas e funcionais. O domínio secretor posicionase entre a região proximal e a distal e é caracterizado por possuir um citoplasma repleto de vesículas contendo brocossomos (figura 6). Os brocossomos são secretados pela região expandida do TM, liberados na luz do intestino e, após serem eliminados pelo animal, são espalhados no tegumento com auxílio das patas traseiras (Raikitov, 1995). Forma-se assim uma camada externa protetora que tem como propriedade repelir água e outros compostos, diminuindo também a perda de água e de outras substâncias pela cigarrinha (Raikitov, 1995, 1999).

Como mencionado anteriormente, o IM do hemíptera $P$. maidis, por sua vez, não exibe diferenciações anatômicas evidentes. No entanto, do ponto de vista da ultraestrutura, algumas diferenças podem ser apontadas entre os enterócitos de IMa e IMp. A região do IMa apresenta enterócitos com o citoplasma repleto de mitocôndrias, principalmente em sua porção apical, além de áreas de Golgi e elementos do retículo endoplasmático rugoso. Suas microvilosidades são mais longas e estreitas e há grande quantidade de vesículas presentes no lúmen do intestino que se apresentam em diferentes diâmetros e eletrondensidades. Essas vesículas podem estar associadas ao ápice ou lateral das microvilosidades ou livres na luz do tubo. Os enterócitos do IMp apresentam um citoplasma com menos organelas que IMa, sendo que as mitocôndrias encontram-se associadas principalmente às poucas e estreitas invaginações da membrana plasmática basal. As diferenças ultraestruturais encontradas entre os enterócitos de IMa e IMp sugerem que os primeiros, mais ricos em organelas relacionadas à rota secretora (Rothman \& Orci, 1992) estejam mais comprometidos com uma função secretora do que os enterócitos de IMp. 
As microvilosidades dos enterócitos de P.maidis são mais curtas e as membranas a elas associadas formam um padrão diverso do encontrado nas outras duas espécies de hemípteros estudados. Tais membranas unem-se sobre as microvilosidades, formando uma camada eletrondensa espessa que recobre o epitélio em toda a sua extensão que pode constituir uma barreira de difusão importante entre o epitélio e a luz intestinal, que até certo ponto, teria alguma analogia com a membrana peritrófica encontrada em outros insetos.

De acordo com os resultados obtidos, fica evidente que, apesar das semelhanças encontradas com o complexo do tipo MLC, o sistema digestivo de $P$. maidis exibe um complexo luminal de membranas diferente do observado nas espécies da infraordem Cicadomorpha, de modo que este foi denominado membranas luminais em forma de chama modificadas (MLCm).

Em relação aos representantes da ordem Thysanoptera os resultados obtidos com o estudo morfológico do sistema digestivo revelaram vários detalhes importantes que eram desconhecidos até o momento.

A ordem Thysanoptera, conforme mencionado anteriormente, é constituída, de modo geral, por indivíduos de tamanho bastante diminuto (alguns poucos milímetros de comprimento), o que dificulta bastante qualquer tipo de análise morfológica mais detalhada que exija dissecção dos animais.

A organização anatômica do sistema digestivo das três espécies estudadas é bastante semelhante à descrita na literatura para espécies da subordem Terebrantia (Ullman et al., 1989). O IM é um tubo alongado, indiferenciado anatomicamente e que se encontra dobrado no interior do corpo do inseto sendo que ao final da sua região posterior, na altura do piloro, é possível observar a presença de três túbulos de Malpighi ao contrário de Hemiptera onde são encontrados quatro túbulos. Conforme descrito anteriormente, o IM da espécie $F$. schultzei não apresenta diferenciações anatômicas muito evidentes, com ausência de uma CF ausente. Do ponto de vista da ultraestrutura, o IM pode ser dividido em região anterior e posterior. Os enterócitos das regiões anterior e posterior possuem evidências de grande atividade metabólica, como uma abundância de áreas de Golgi, elementos do retículo endoplasmático bem desenvolvidos e mitocôndrias concentradas no 
citoplasma apical junto à base das microvilosidades. Associado ao ápice das microvilosidades, observa-se a existência de um complexo luminal de membranas que se assemelha às MLC descritas para diversas espécies de hemípteros da infraordem Cicadomorpha (Utiyama, 2011; 2016; Utiyama et al., 2017).

Em um dos poucos trabalhos acerca da morfofisiologia da digestão em tripes, Silva, et al. (2004), do nosso grupo de pesquisa, realizou um estudo que tinha como objetivo detectar a ocorrência de um complexo luminal de membranas em representantes do grupo Paraneoptera, analisando, entre outras, uma espécie da ordem Thysanoptera pertencente ao gênero Frankliniella. Os resultados apresentados neste estudo sugerem a presença de membranas perimicrovilares (MPM) nestas espécies. Entretanto, os dados apresentados neste trabalho apontam para uma organização do complexo luminal de membranas distinta, similar às MLC descritas em diversas espécies da ordem Hemiptera (Utiyama, 2011; 2016; Utiyama et al., 2017). De fato, os resultados apresentados por Silva et al. (2004) não mostram, na verdade, evidências claras da presença de MPM na forma, por exemplo, de perfis circulares concêntricos em torno das microvilosidades, que deveriam ser observadas a partir de cortes transversais destas estruturas se este tipo de complexo estivesse presente. Tudo leva a crer, portanto, que as imagens obtidas nesse trabalho tenham sido mal interpretadas e o complexo luminal presente em Frankliniella seja mesmo do tipo MLC.

De um modo geral, o IM da outra espécie de Thysanoptera estudada, a F. vespiformes apresenta características ultraestruturais semelhantes à observada para F. schultzei. Uma de suas peculiaridades, entretanto, é a ocorrência de um padrão diferente na organização das microvilosidades da região anterior do IM. Elas são relativamente mais curtas do que as descritas para outras espécies e se encontram emaranhadas, contrastando com a disposição regular observada nas demais regiões. O complexo luminal de membranas encontrado nessa região também não segue um padrão regular em sua disposição, apenas projetando-se em direção ao lúmen associadas à diversas vesículas de diferentes tamanhos. A presença de vesículas e membranas associadas ao ápice das microvilosidades e a ausência de figuras 
membranosas circulares concêntricas em cortes transversais destas estruturas indicam que se trata de um complexo luminal de membranas do tipo MLC. A região média do $\mathrm{IM}$, por sua vez, apresenta um complexo luminal de membranas claramente do tipo MLC, semelhante ao descrito neste trabalho para as diversas espécies de hemípteros da subordem Auchenorrhyncha.

Finalmente, a análise ultraestrutural do IM de Liothrips sp. evidenciou algumas diferenças importantes em relação às outras duas espécies de Thysanoptera estudadas. A principal característica observada é uma aparente ausência de um complexo luminal de membranas elaborado, notando-se apenas a presença uma cobertura membranosa no ápice das microvilosidades de IMa e de raras e curtas membranas que se projetam dos ápices das microvilosidades de IMp. Em uma análise mais detalhada é possível observar estruturas que se assemelham a trabéculas entre as microvilosidades de IMp. Essas estruturas podem ser encontradas por toda a extensão desta região do intestino do animal, tendo sido descritas inicialmente por Kitajima (1975) que as considerou como sendo um glicocálix diferenciado. Apesar de sua função ainda ser desconhecida, supõe-se que tenham papel estrutural, auxiliando numa maior coesão estrutural do tecido.

\section{Panorama do Sistema Digestivo em Condylognatha}

O presente trabalho constitui uma contribuição significativa para a melhoria do conhecimento acerca da morfologia funcional do sistema digestivo em Hemiptera e Thysanoptera, uma vez que as informações disponíveis atualmente na literatura especializada ainda são bastante fragmentadas e, muitas vezes, conflitantes. Nos últimos anos, foram realizados principalmente, pelo nosso grupo de pesquisa, estudos importantes sobre a organização do sistema digestivo em representantes da ordem Hemiptera, que permitiram evidenciar detalhes dessa organização e a existência de uma diversidade morfofuncional insuspeitada até então (Utiyama, 2011; 2016; Utiyama et al., 2017). No caso dos Thysanoptera, as informações encontradas na literatura são ainda mais escassas do que as dos Hemiptera. Assim sendo, os resultados 
obtidos neste trabalho contribuem para preencher uma parte desta importante lacuna, embora muito ainda seja necessário pesquisar para compreender os múltiplos detalhes do processo digestivo neste importante grupo de insetos.

Conforme bastante discutido anteriormente, os insetos do grupo Condylognatha não possuem uma membrana peritrófica no lúmen do intestino médio, como na maioria dos insetos. Em seu lugar, observa-se um complexo luminal de membranas lipoproteicas associadas às microvilosidades e que se projetam em direção à luz do intestino. De forma resumida, e para efeito de recordação, pode-se dizer que existem três tipos principais descritos na literatura com relação à organização do complexo luminal de membranas: as membranas perimicrovilares (MPM), as membranas perimicrovilares modificadas (MPMm) e as membranas luminais em forma de chama (MLC). A distribuição destes complexos parece estar relacionada à filogenia do grupo, de modo que cada subordem apresenta uma organização de membranas característica. As MPM são comumente encontradas em espécies da subordem Heteroptera (percevejos). Os insetos deste grupo possuem dietas variadas, com integrantes que se alimentam de tecidos vegetais ou animais, podendo ser predadores, hematófagos, sugadores de seiva, entre outros. As espécies que compõem a subordem Sternorrhyncha (afídeos e pulgões) são especializadas em se alimentar de floema das plantas e apresentam um complexo luminal de membranas do tipo MPMm. Por fim, a subordem Auchenorrhyncha é constituída por animais que se alimentam de xilema, floema ou mesofilo e possuem membranas do tipo MLC, indicando que o hábito alimentar das espécies, aparentemente, pouco influencia a organização de suas membranas luminais.

Como se recorda, a ordem Hemiptera é integrante da superordem Paraneoptera, que também inclui as ordens Psocoptera, Phthiraptera e Thysanoptera. Em um trabalho realizado pelo nosso grupo de pesquisa (Gonçalves, 2002) numa espécie da ordem Phthiraptera (Haematopinus suis), assim como em raras imagens disponíveis na literatura de espécies dessa ordem e da ordem Psocoptera sobre a morfofisiologia do sistema digestivo, indicam que a membrana peritrófica também está ausente nesses grupos de insetos. Este fato sugere que tal estrutura tenha sido perdida no ancestral de 
toda superordem Paraneoptera (Gonçalves, 2002; Silva et al., 2004). Mais interessante ainda, é que, aparentemente, não só a membrana peritrófica está ausente nas ordens Phthiraptera e Psocoptera, como também não se detecta a ocorrência de qualquer tipo de complexo luminal de membranas. No entanto, a falta de estudos mais detalhados sobre o sistema digestivo e hábitos alimentares, especialmente dos integrantes das ordens Psocoptera e Phthiraptera, ainda dificultam uma compreensão mais abrangente dos fenômenos evolutivos que levaram à perda da membrana peritrófica no ancestral dos Paraneoptera. Uma hipótese possível que explicaria esta perda seria que o ancestral deste grupo tenha se adaptado a uma fonte alimentar baseada em fluidos orgânicos ou detritos, cuja composição apresenta moléculas orgânicas menos complexas e mais facilmente digeríveis. Deste modo, o processo digestivo neste ancestral poderia ser simplificado a ponto de a compartimentalização do lúmen do intestino médio deixar de ser uma vantagem, resultando no desaparecimento da membrana peritrófica ao longo da evolução (Terra,1988).

De acordo com a literatura (Terra, 1988; Terra \& Ferreira 2012), o complexo luminal de membranas possivelmente tenha se originado em um ancestral do grupo Condylognatha (ordens Hemiptera e Thysanoptera), como uma adaptação relacionada a um hábito sugador de seiva das plantas, semelhante aos atuais integrantes da subordem Auchenorrhyncha. Nesta visão, este complexo luminal de membranas presente no ancestral seria, provavelmente, do tipo MPM que aumentaria a eficiência na absorção de moléculas orgânicas, principalmente aminoácidos, que são nutrientes escassos na seiva. Como se recorda, transportadores de potássio absorveriam ativamente estes íons para o interior dos enterócitos a partir do EPM, formando um gradiente de concentração entre o lúmen e o EPM. Este gradiente geraria a energia potencial utilizada para o transporte de aminoácidos através da MPM por cotransportadores de potássio e aminoácidos. Uma vez no EPM, estes nutrientes se difundiriam e seriam absorvidos por transportadores específicos presentes na membrana microvilar. As MPM típicas podem ser observadas, principalmente, em representantes da subordem Heteroptera atuais, que, apesar de adotarem secundariamente uma dieta mais complexa e que exige 
digestão luminal de grandes moléculas orgânicas, mantiveram estas membranas que permitem a compartimentalização do processo digestivo de modo semelhante à membrana peritrófica (Terra, 1988; Terra \& Ferreira, 2012).

Os integrantes da subordem Sternorrhyncha possuem um complexo luminal de membranas organizadas em MPMm. Este complexo supostamente evoluiu a partir de um ancestral MPM, após a adaptação destes insetos a uma alimentação baseada em floema, que é rica em sacarose e hiperosmótica com relação à hemolinfa. Uma das características do modelo MPMm é a modificação das microvilosidades dos enterócitos em um sistema de lamelas que possuem trabéculas conectando-as entre si. Este modelo de arquitetura celular deve contribuir para uma maior resistência do epitélio à alta pressão osmótica causada por esse tipo de alimento. Com o surgimento destas trabéculas ao longo da evolução e a consequente limitação do espaço entre as microvilosidades, as MPM ancestrais teriam sido substituídas pela MPMm (Cristofoletti et al., 2003).

Os membros da subordem Auchenorrhyncha, por ouro lado, parecem apresentar uma grande diversidade de tipos de organização do complexo luminal de membranas. Em um estudo realizado com uma espécie sugadora de xilema Phylloscelis atra (Dictyopharidae), integrante da infraordem Fulgoromorpha, foi descrito um complexo luminal do tipo MPM, semelhante à observada em integrantes da subordem Heteroptera (Reger, 1971), resultado este não confirmado pelo presente trabalho. As MLC, por sua vez, foram observadas em insetos da infraordem Cicadomorpha da subordem Auchenorrhyncha, que são animais especializados em se alimentar de fluidos vegetais. Com base nesses dados, a conclusão inicial seria que as MLC provavelmente teriam evoluído a partir de uma organização do tipo MPM, como uma adaptação a um hábito alimentar baseado especificamente em xilema. No entanto, as pressões seletivas e fenômenos evolutivos envolvidos nesse processo não são conhecidos. Tal adaptação deve ter ocorrido paralelamente à evolução da câmara de filtração em Cicadomorpha, cujo órgão constitui um auxílio importante na absorção de nutrientes essenciais pela eliminação do excesso de água presente no xilema. 
Entretanto, a visão mais tradicional encontrada na literatura sobre a evolução da organização morfofuncional do processo digestivo em Hemiptera não parece se sustentar mais quando confrontada com dados mais recentes. Nessa visão, o complexo luminal de membranas do tipo MPM teria surgido no ancestral das ordens Hemiptera e Thysanoptera, numa adaptação para um hábito sugador de seiva semelhante aos atuais Auchenorrhyncha. No entanto, a descoberta da existência de uma organização do complexo luminal de tipo MLC, que difere significativamente da organização MPM atribuída ao ancestral comum entre as duas ordens, se mostra como um fator complicante no suporte dessa visão tradicional (Utiyama, 2011; 2016). Além disso, os dados apresentados no presente trabalho demonstram a ocorrência das MLC também em representantes da ordem Thysanoptera, indicando, portanto, que este seria o complexo luminal de membranas presente no ancestral comum ao grupo Condylognatha. Deste modo, com base nestas informações, uma nova hipótese foi aventada sobre a origem e evolução do complexo luminal de membranas em Condylognatha. Neste novo panorama, o ancestral hipotético das ordens Hemiptera e Thysanoptera seria um inseto adaptado ao hábito sugador de seiva, que poderia apresentar um complexo luminal de membranas com organização semelhante às MLC (ver esquema mais adiante). Os sugadores de xilema que integram a infraordem Cicadomorpha (da subordem Auchenorrhyncha) atuais, que apresentam hábitos alimentares semelhantes aos ancestrais, teriam mantido a mesma organização geral do MLC. As MPMm teriam sido selecionadas como variações da MLC no ancestral da subordem Sternorrhyncha como um mecanismo que proporcionaria vantagens evolutivas para um hábito alimentar baseado em floema. As MPM, por sua vez, teriam derivado a partir das MLC no ancestral compartilhado entre a subordem Heteroptera e a infraordem Fulgoromorpha (da subordem Auchenorrhyncha). Entretanto, os dados obtidos no presente trabalho com a espécie de Fulgoromorpha, $P$. maids, não corroboram a existência de um complexo luminal do tipo MPM como o descrito por Reger (1971). De fato, uma inspeção mais cuidadosa das imagens publicadas por este autor mostra um padrão organizacional de membranas não condizente com uma estrutura típica de MPM. Assim, o complexo luminal de membranas em Fulgoromorpha teria uma arquitetura diversa da MPM e sim mais próxima a das MLC. As MPM teriam 
surgido, então, apenas no ancestral dos Heteroptera como um mecanismo que promoveria a compartimentalização do processo digestivo adaptado secundariamente a uma alimentação nutricionalmente mais complexa que envolve digestão luminal de polímeros. Os integrantes da ordem Thysanoptera, por sua vez, herdaram a organização de membranas luminais do tipo MLC do ancestral, mas evoluíram para hábitos alimentares distintos. Assim, os tripes da subordem Terebrantia mantiveram, em princípio, o complexo luminal de membranas ancestral ao longo da evolução. Entretanto, os membros da subordem Tubulifera apresentam um complexo luminal bem pouco elaborado, com poucas membranas associadas às microvilosidades, aparentemente muito diverso do padrão MLC. O surgimento deste padrão de membranas luminais ao longo da evolução deste grupo de Thysanoptera pode ter sido resultado da adaptação destes insetos a um hábito alimentar fungívoro, diverso dos Terebrantia.

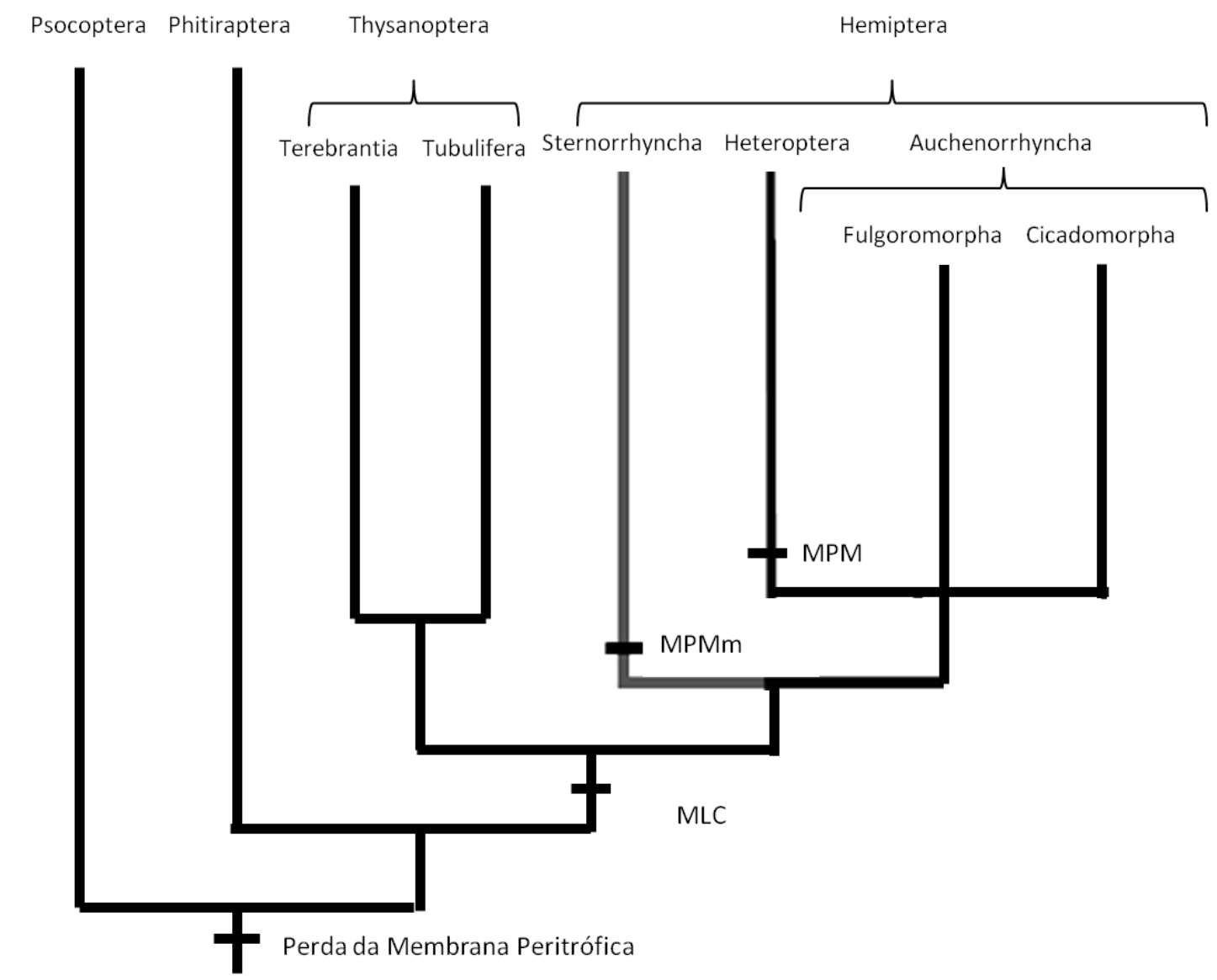

As hipóteses sobre a evolução da organização do processo digestivo em Hemiptera e Thysanoptera são baseadas em resultados obtidos em diversas 
espécies de hemípteros e tripes que consideram, principalmente, os diferentes tipos de complexos luminais de membranas. É importante salientar que os mecanismos celulares que originam os diferentes tipos de complexos luminais parecem ser muito diversos. Assim, as MPM são formadas por dois eventos consecutivos de fusão de vesículas de membrana dupla, de modo que a membrana externa se funde com a membrana plasmática e a interna com a MPM (Silva et al., 1995). Estas vesículas são originadas a partir das cisternas trans-Golgi, envoltas por um rearranjo de cisternas adjacentes (Andries \& Torpier, 1982; Silva et al., 1995). As MPM revestem as microvilosidades mantendo uma distância constante entre as membranas, formando um novo compartimento, o espaço perimicrovilar (Lane \& Harrison, 1979; Terra, 1988; 1990; 2001; Silva et al., 1995; Terra \& Ferreira, 2012). As MPMm, por sua vez, são produzidas por um mecanismo semelhante ao que ocorre na origem das MPM, pois são produto direto da rota intracelular de secreção, que envolvem o retículo endoplasmático, o complexo de Golgi e vesículas de secreção (Rothman \& Orci, 1992). No entanto não há a formação de vesículas de membrana dupla, neste caso. As membranas do complexo luminal MPMm encontram-se associadas às extremidades das microvilosidades e possuem aspecto enovelado, não formando compartimentos fechados (Cristofoletti et al., 2003). Diferentemente dos outros dois modelos, as MLC não são produto direto da rota de secretora e sim são originadas a partir da vesiculação das extremidades das microvilosidades. Conforme estas vesículas avançam pelo lúmen do intestino médio, elas se alongam e se fundem, formando, como vimos, figuras semelhantes a chamas (Utiyama, 2011, 2016). Além destes modelos descritos na literatura, existem, ainda, os complexos luminais de membrana observados em Peregrinus maidis e Liothrips sp., mas estudos adicionais são necessários para se determinar os mecanismos celulares envolvidos em sua produção. O fato de a formação dos diferentes complexos luminais de membranas envolverem mecanismos celulares tão diversos dificulta a compreensão dos reais fatores seletivos que levaram à diversificação destes complexos. Assim, para se ter uma visão mais precisa acerca dos fenômenos evolutivos que resultaram na formação dos diferentes tipos de complexos luminais de membranas, torna-se necessária a obtenção de mais informações que ainda não se encontram disponíveis na literatura. 
A evolução da organização morfofuncional do sistema digestivo nos Condylognata é caracterizada, portanto, pelo surgimento de um complexo luminal de membranas associado às microvilosidades dos enterócitos do intestino médio destes organismos. Embora ainda se desconheça detalhes da função dessa estrutura, acredita-se que ela possa estar relacionada a um aumento da eficiência do processo digestivo por ampliar a área de contato do epitélio intestinal com o alimento, permitindo a fixação de proteínas de membrana ou outros componentes essenciais envolvidos principalmente no transporte de nutrientes e/ou íons. Um papel importante que deve estar relacionado a estes complexos é o da compartimentalização do processo digestivo. De fato, Utiyama et al. (2017), com o uso de traçadores eletrondensos injetados na luz do intestino, evidenciou a existência de uma barreira de permeabilidade associada às MLC em uma espécie de Auchenorrhyncha (Bucephalogonia xanthophis). Em Heteroptera, as MPM delimitam o espaço perimicrovilar, que claramente compartimentaliza 0 processo digestivo destes insetos. Nos Sternorrhyncha, as MPMm não delimitam um compartimento fechado, como nos outros dois modelos. Entretanto, estas membranas projetam-se ao lúmen e podem concentrar proteínas, nutrientes e outros solutos, formando microambientes com composição distinta do restante do conteúdo luminal (Cristofoletti et al., 2003). Este mesmo argumento pode ser aplicado ao complexo luminal de membranas bem pouco evidente observado em Liothrips $s p$., que, aparentemente, não exibe compartimentalização luminal no intestino. Deste modo, pode-se considerar que tais microambientes correspondam a compartimentos de acesso restrito no lúmen intestinal. Neste ponto, é interessante salientar que os insetos da ordem Phthiraptera, que incluem os piolhos, não apresentam qualquer tipo de membranas luminais associadas ao epitélio intestinal. Isso foi constatado em um estudo realizado em nosso laboratório com a espécie hematófaga Haematopinus suis (Phthiraptera: Anoplura) (Gonçalves, 2002). Neste caso, o sangue ingerido pelo inseto forma coágulos no interior do lúmen intestinal que pode acarretar na formação de microambientes bioquimicamente distintos entre seu interior e a luz do intestino. Deste modo, a digestão do alimento ocorreria em etapas distintas, tendo início a partir da superfície do coágulo até as porções mais internas. Com relação aos integrantes da ordem 
Psocoptera, não há, praticamente, informações sobre a organização do sistema digestivo destes insetos. Em um único trabalho existente na literatura, com uma espécie da família Liposcelidae, não se observou qualquer tipo de membrana luminal ou indicação da existência de microambientes relacionados a uma possível compartimentalização da luz do intestino (Silva et al., 2003).

As informações disponíveis até o momento indicam que, embora a compartimentalização do processo digestivo nos insetos mediada pela membrana peritrófica tenha sido, aparentemente, perdida ao longo da evolução dos Paraneoptera, mecanismos alternativos foram selecionados no sentido de promover algum nível de compartimentalização no intestino médio destes insetos. A membrana peritrófica característica de insetos não pertencentes aos Paraneoptera é constituída, basicamente, por um complexo de quitina e peritrofinas (Terra, 2001), substituída, nos Condylognata, como exaustivamente discutido acima, por um complexo luminal de membranas de diversos tipos, mas de natureza, em princípio, predominantemente lipoproteica. A presença de quitina, um componente típico de uma membrana peritrófica, não seria, a priori, esperada nesses complexos. De fato, a análise recente do transcriptoma do heteróptero $D$. peruvianus não indica a existência de uma quitina sintase específica do sistema digestivo, mas apenas uma de expressão cuticular (Terra et al., não publicado). Entretanto, os resultados obtidos no presente trabalho com microscopia de fluorescência mostram, claramente, a existência de quitina no complexo luminal de membranas de $M$. fimbriolata e $D$. maidis. Como contraprova, a mesma reação de detecção de quitina por fluorescência foi realizada em $D$. peruvianus, que resultou, como esperado, numa ausência de quitina no tubo digestivo desta espécie. Dados ainda mais recentes, referentes à uma análise preliminar do transcriptoma de $M$. fimbriolata corroboram estes resultados, indicando a existência de uma quitina sintase específica do sistema digestivo desta espécie (Terra et al., não publicado), além daquela de expressão cuticular. Estes achados, bastantes surpreendentes, certamente merecem um estudo mais aprofundado a ser realizado, a curto prazo, com outras espécies de Condylognatha, para que se tenha um panorama mais abrangente e compreensível dos múltiplos e complexos fatores envolvidos no processo evolutivo do sistema digestivo nos Paraneoptera. 
Conclusões 
Os dados apresentados neste trabalho evidenciam a ocorrência de uma enorme diversidade na organização do sistema digestivo entre os insetos do grupo Condylognatha, principalmente com relação ao complexo luminal de membranas. Um aspecto importante deste estudo foi a comprovação da existência um complexo luminal exibindo uma arquitetura aparentemente bem diversa entre os representantes estudados da ordem Thysanoptera, mas diferente do modelo MPM geralmente descrito na literatura como característico deste grupo. Além disso, as informações levantadas neste trabalho dão suporte a um novo panorama para a evolução do sistema digestivo nos Hemiptera e Thysanoptera, no qual o ancestral comum não apresentaria uma organização do complexo luminal de membranas do tipo MPM, mas sim MLC, sendo que o padrão MPM teria surgido nos Hemiptera apenas no grupo dos Heteroptera. A detecção de quitina no complexo luminal de membranas em duas espécies estudadas de Hemiptera/Auchenorrhyncha, mas ausente em uma espécie de Heteroptera usada como controle, é um resultado não esperado que indica que a natureza dessa estrutura luminal do intestino médio dos Condylognatha é muito mais complicada e elaborada do que se imaginava a partir dos dados existentes atualmente na literatura. 
Resumo 
O presente trabalho apresenta um estudo detalhado da morfologia comparada do sistema digestivo de espécies representantes das ordens Hemiptera e Thysanoptera, numa perspectiva evolutiva, tendo como foco principal a análise da organização do complexo luminal de membranas existente no intestino médio dessas espécies, cuja presença no intestino médio constitui uma das características mais peculiares encontradas nestes grupos de insetos.

As espécies das ordens Hemiptera e Thysanoptera compreendem o chamado grupo dos Condylognatha que reúne organismos com hábitos alimentares diversos, mas predominantemente sugadores. A grande maioria dos insetos apresenta, no interior do intestino médio, um estrutura luminal quitino-proteica denominada de membrana peritrófica, que, entre outras funções, compartimentaliza o processo digestivo. No entanto, nos membros do grupo Condylognatha esta estrutura está ausente, sendo substituída por um complexo membranoso bastante elaborado, associado às microvilosidades dos enterócitos, denominado de complexo luminal de membranas. Existem, basicamente, três tipos de complexos luminais descritos na literatura: as membranas perimicrovilares (MPM), as membranas perimicrovilares modificadas (MPMm) e as membranas luminais em forma de chama (MLC). As primeiras descrições deste complexo, do tipo MPM, foram feitas em hemípteros da subordem Heteroptera. No entanto, a presença deste tipo de complexo também foi notada em espécies de Thysanoptera, sugerindo uma origem evolutiva das MPM a partir de um ancestral comum dos Condylognatha, como uma adaptação ao hábito alimentar sugador de seiva. Estudos posteriores evidenciaram a ocorrência dos demais tipos de complexo em membros das outras subordens de Hemiptera, as MPMm em Sternorrhyncha e, mais recentemente, as membranas luminais em forma de chama MLC em Auchenorrhyncha, o que sugerem ser essa estrutura luminal muito mais diversa morfologicamente do que se acreditava inicialmente. Neste contexto, o foco principal deste trabalho foi realizar um estudo morfofuncional comparativo do sistema digestivo em representantes de Condylognatha, com o objetivo principal de se detectar os tipos de complexo luminal de membranas presentes e descrever detalhes de sua organização. Para isso, foram realizados estudos 
anatômicos, histológicos e ultraestruturais do sistema digestivo das espécies selecionadas, incluindo técnicas de microscopia eletrônica de transmissão, varredura e de fluorescência confocal. Assim, foram utilizadas três espécies de Hemiptera, subordem Auchenorrhyncha: Dalbulus maidis (Cicadellidae) e Mahanarva fimbriolata (Cercopidae) que pertencem à infraordem Cicadormorpha, e Peregrinus maidis (Delphacidae), da infraordem Fulgoromorpha. Além disso, foram estudados três representantes de Thysanoptera: Frankliniella schultzei (Thripidae), Franklinothrips vespiformes (Aeolothripidae), Leucothrips furcatus (Dendothripinae) e Liothrips $s p$. (Phlaeothripinae), sendo as três primeiras integrantes da subordem Terebrantia e a última, Tubulifera.

Os resultados obtidos revelaram que as espécies $M$. fimbriolata e $D$. maidis possuem um complexo luminal muito semelhante ao do tipo MLC. Por sua vez, o complexo luminal membranas da espécie $P$. maidis revelou-se bastante diferente das outras espécies conhecidas de Auchenorrhyncha, que pode ser considerado uma modificação do modelo MLC. Neste caso, destacase a presença de uma camada membranosa eletrondensa aparentemente revestindo todo o complexo de membranas em sua face voltada para a luz do intestino. Diferenças significativas foram observadas na arquitetura do complexo luminal entre as espécies analisadas de Thysanoptera. Enquanto que nas espécies $F$. schultzei e $F$. vespiformes observa-se um complexo luminal de membranas similar ao tipo MLC, a espécie Liothrips sp. não apresenta um complexo luminal de membranas evidente, mas apenas algumas membranas curtas e raras associadas aos ápices das microvilosidades. Além disso, pequenas trabéculas são também observadas ao longo das microvilosidades dos enterócitos desta espécie, parecendo conectá-las lateralmente, talvez atuando numa função de reforço desta estrutura. Os resultados obtidos em Thysanoptera não apoiam a existência de um complexo luminal de membranas do tipo MPM como descrito na literatura. Assim, as informações levantadas neste trabalho dão suporte a um novo cenário para a evolução do sistema digestivo dos Hemiptera e Thysanoptera, no qual o ancestral comum não apresentaria uma organização do complexo luminal de membranas do tipo MPM, como correntemente descrito na literatura, mas sim 
do tipo MLC, sendo que o padrão MPM teria surgido nos Hemiptera apenas no grupo dos Heteroptera.

A detecção de quitina no complexo luminal do intestino médio de $D$. maidis e $M$. fimbriolata por microscopia de fluorescência, utilizando-se um conjugado de WGA-fluoresceína, é um resultado surpreendente e não esperado uma vez ser a quitina, reconhecidamente, um componente importante da membrana peritrófica e não, a priori, de um complexo membranoso de natureza lipoproteica. Por outro lado, a não detecção de quitina em uma espécie de Heteroptera (Dysdercus peruvianis), que possui um complexo luminal de tipo MPM, usada como controle, mostra que a natureza do complexo luminal de membranas nos Condylognatha é muito mais complicada e elaborada do que se pensava inicialmente. 
Abstract 
This work presents a comprehensive study of the morphology of the digestive system of species of the orders Hemiptera and Thysanoptera, in an evolutionary approach. The main focus of the study is the analysis of the organization of the luminal complex of membranes in the midgut of these species whose presence constitutes one of the most peculiar characteristics found in the insects of the two orders.

The species of the orders Hemiptera and Thysanoptera comprise the socalled group of Condylognatha, formed by insects showing variable feeding habits, but mostly sap-sucking ones. The vast majority of insects presents, in their midgut, a chitin-proteic luminal structure called peritrophic membrane which compartmentalizes the digestive process, among other functions. However, this structure is absent in the members of the group Condylognatha, which shows, instead, a very elaborated membranous complex associated to the microvilli of the enterocytes called luminal membrane complex. There are basically three types of luminal membrane complexes described in the literature: the perimicrovilar membranes (PMM), the modified perimicrovilar membranes (PMMm) and the flame-like membranes (FLM). The first descriptions of this complex, of the PMM type, were made in hemipteran insects of the suborder Heteroptera, but there are also some descriptions of PMM in species of the order Thysanoptera. These observations lead to the suggestion of an evolutionary origin of this type of complex from a common ancestral of Condylognatha as an adaptation to a sap-sucking habit. Further studies show the occurrence of the other types of luminal complex in members of the other hemipteran suborders - PMMm in Sternorrhyncha and, more recently, FLM in Auchenorrhyncha - which suggests that this luminal structure is much more diverse than previously expected.

In this context, the main focus of this work was to perform a comparative morphofunctional study of the digestive system of species belonging to the group Condylognatha in order to detect and describe the different types of luminal membrane complex found in these insects. To achieve this goal, anatomical, histological and ultrastructural analysis were performed on the digestive system of selected species, using transmission and scanning electron microscopy, along with fluorescence confocal microscopy techniques. Three 
hemipteran species, belonging to the suborder Auchenorrhyncha, were studied: Dalbulus maidis (Cicadellidae) and Mahanarva fimbriolata (Cercopidae) of the infraorder Cicadormorpha, and Peregrinus maidis (Delphacidae), of the infraorder Fulgonomorpha. Three other species of the order Thysanoptera were also explored: Frankliniella schultzei (Thripidae), Franklinothrips vespiformes (Aeolothripidae) and Liothrips sp. (Phlaeothripinae), where the first two belong to the suborder Terebrantia and the last one to the suborder Tubulifera.

The results presented in this work show that the species $M$. fimbriolata and $D$. maidis have a luminal membrane complex very similar to the FLM type. In contrast, the species $P$. maidis presented a very different organization when compared to the known species of the suborder Auchenorrhyncha, which should be considered to be a modification of the FLM model. In this case, a membranous electron-dense layer was detected, which apparently coats the entire membrane complex. Important differences were observed in the structure of the luminal complex among the analyzed thysanopteran species. In the midgut of $F$. schultzei and $F$. vespiformes there is a membrane complex similar to the FLM type. However, the species Liothrips $s p$. does not seem to present any type of membranous complex, displaying only a few short membranes associated to the microvilli. In addition to that, small structures, similar to trabeculae, can be observed along the microvilli of the enterocytes of this species, apparently connecting them laterally, reinforcing this structure. Thus, the results obtained in Thysanoptera do not support the existence of a PMM type of complex in this order, as described in the literature. Therefore, the data collected in this work present a new scenario to the evolution of the digestive system of Hemiptera and Thysanoptera, where the common ancestral would not display a membranous complex of the type PMM, but a FLM complex, with the PMM arising only in the Heteroptera group of Hemiptera.

The detection of chitin in the luminal complex of $D$. maidis and $M$. fimbriolata by fluorescence microscopy, using a WGA-fluorescein conjugate, is an unexpected result since chitin is an important component of the peritrophic membrane and not, a priori, of a lipoproteic membranous complex. On the other hand, the negative detection of chitin in a heteropteran species (Dysdercus peruvianis), which has a PMM luminal complex and was used as control, 
indicate that the nature of the luminal membrane complex in the Condylognatha group is far more complicated and elaborate than previously thought. 
Referências Bibliográficas ${ }^{1}$ 
AMMAR, E.D. Ultrastructure of the salivary glands of the planthopper, Peregrinus maidis (Ashmead) (Homoptera: Delphacidae). International Journal of Insect Morphology and Embryology. 1986. V. 15, n. 5-6, p. 417-428.

ANDRIES, J. C.; TORPIER, G. Extracellular brush border coat of lipid membranes in the midgut of Nepa cinerea (Insecta, Heteroptera): ultrastructure and genesis. Biology of the Cell. 1982. V. 46, p. 195-202.

ARMSTRONG, P. B.; PARENTI, D. Scanning electron microscopy of thick embryo, Developmental Biology. 1973. V. 33, p. 457-462.

ASHFORD, D. A.; SMITH, W. A.; DOUGLAS, A. E. Living on a high sugar diet: the fate of sucrose ingested by a phloem-feeding insect, the pea aphid Acyrthosiphon pisum. Journal of Insect Physiology. 2000. V. 46, p. 335-341.

BEÇAK, W.; PAULETE, j. Técnicas de citologia e histologia. Rio de Janeiro: Livros técnicos e científicos. 1976. V. 1, p. 242-251.

BERETTA, M. J. G.; GARCIA, JR. A.; LEE, R. F.; DERRICK, K. S.; BARTLE, G.; TOMÉ NETO, J. Observation on citrus variegated chlorosis in Brazil. Proc of the $12^{\text {th }}$ In: Conference of the international. IOCV. 12, India, 1993. p. 291-293.

BUCKMAN, R. S.; MOUND, L. A.; WHITING, M. F. Phylogeny of thrips (insecta Thysanoptera) based on five molecular loci. Systematic Entomology. 2013. V. 38, p 123 - 133.

CHAPMAN, R. F. The insects. $4^{\text {th }}$ ed. Cambridge University Press. 1998. P. 38-68.

CHEUNG, W. W. K.; MARSHALL, A. T. Water and ion regulation in cicadas in relation to xylem feeding. Journal of Insect Physiology. 1973a. V. 19, p. 1801-1816.

CHEUNG, W. W. K.; MARSHALL, A. T. Studies on water and ion transport in homopteran insects: ultrastructure and cytochemistry of the cicadoid and cercopid midgut. Tissue and Cell. 1973b. V. 5, p. 651-669.

CRISTOFOLETTI, P. T.; RIBEIRO, A. F.; DERAISON, C.; RAHBÉ, Y.; TERRA, W. R. Midgut adaptation and digestive enzyme distribution in a phloem feeding insect, the pea aphid Acyrthosiphon pisum. Journal of Insect Physiology. 2003. V. 49, p. 11-24. 
CRYAN, J. R.; URBAN, J. M. Higher-level phylogeny of the insect order Hemiptera: is Auchenorrhyncha really paraphyletic?. Systematic Entomology. 2011. p. 1-15.

DE NIGRI, J. D. Clorose variegada dos citros: nova anomalia afetando pomares em São Paulo e Minas Gerais. Com Tec, n. 82, Ect. Rural, CATI, Campinas. 1990.

DEL BENE, G.; DALLAI, R.; MARCHINI, D. Ultrastructure of the midgut and the adhering tubular salivary glands of Frankliniella occidentalis (Pergande) (Thysanoptera: Thripidae). International Journal of Insect Morphology and Embryology. 1991.V. 20, n. 1-2, p. 15-24,

DIAS, R.O.; CARDOSO, C.; PIMENTEL, A.C.; DAMASCENO, T.F.; FERREIRA, C.; TERRA, W.R. The roles of mucus-forming mucins, peritrophins and peritrophins with mucin domains in the insect midgut. Insect Molecular Biology. 2018.V. 27, p. 46-60.

DONADIO, L. C.; MOREIRA, C. S. Clorose Variegada dos Citros. Edição Comemorativa do $15^{\circ}$ Aniversário da Estação Experimental de Citricultura de Bebedouro. 1997.

DOUGLAS, A. E. The nutritional physiology of aphids. Advances in Insect Physiology. 2003. V. 31 p. 73-140.

DOUGLAS, A. E. Phloem-sap feeding by animals: problems and solutions. Journal of Experimental Botany. 2006. V. 57. p. 747-754.

FERREIRA, C.; RIBEIRO, A. F.; GARCIA, E. S.; TERRA, W. R. Digestive enzymes trapped between and associated with the double plasma membranes of Rhodnius prolixus posterior midgut cells. Insect Biochemistry. 1988. V. 18, n. 6, p. 521-530.

FISHER, D. B. Long distance transport. In: BUCHANAN, B. B.; GRUISSEM, W. (Eds). Biochemistry and molecular biology of plants. American Society of Plant Physiology. Rockville, MD, USA. 2000. p. 730-784.

GILLOT, C. Entomology. $2^{\text {nd }}$ Ed. New York. Plenum Press, 1995. p. 195-232.

GONÇALVES, E. K. Estudo morfofuncional do sistema digestivo de Haematopinus suis (Linnaeus, 1758) (Phthiraptera, Anoplura). Tese (Doutorado em Genética/Biologia), Universidade de São Paulo, São Paulo, 2002. 
GOODCHILD, A. J. P. Evolution of the alimentary canal in the Hemiptera. Biological Reviews. 1966. V. 41, n. 1, p. 97-139.

GOURANTON, Jean. Composition, structure, et mode de formation des concrétions minérales dans l'intestin moyen des Homoptères Cercopides. The Journal of Cell Biology. 1968. V. 37, n. 2, p. 316-328.

GRIMALDI, D.; ENGELS, M. S. Evolution of the insects. Cambridge [U.K.]; New York: Cambridge University Press. 2005. p. 287-312.

KITAJIMA, E. W. peculiar type of glycocalyx on the microvili of the midgut epithelial cells of the thrips Franliniella sp.(Thysanoptera, Thripidae). Cytobiologie, 1975.

LANE, N. J.; HARRISON, J. B. Unusual cell-surface modification - double plasmamembrane. Journal of Cell Science. 1979. V. 39, p. 355-372.

LEHANE, M. J. Peritrophic matrix structure and function. Annual Review of Entomology. 1997. V. 42, p.525-550.

LEWIS, T. Thrips: Their Biology, Ecology and Economic Importance. Academic Press, London, 1973.

LINDSAY, K. L.; MARSHALL, A. T. Ultrastructure of the filter chamber complex in the alimentary canal of Eurymela distincta Signoret (Homoptera, Eurymelidae). International Journal of Insect Morphology and Embryology. 1980. V. 9. p. 179198.

MARSHALL, A. T.; CHEUNG, W. W. K. Studies on water and ion transport in homopteran insects: ultrastructure and cytochemistry of the cicadoid and cercopid Malpighian tubules and filter chamber. Tissue and Cell, v. 6, 1974. p. 153-171.

MUSÉUM NATIONAL D'HISTOIRE NATURELLE. Hem-bases: Hemiptera databases in MNHN-Paris. Disponível em: <http://www.hemiptera-databases.org>. Acesso em: 05 nov. 2016.

MOUND, L. A., HEMING, B. S. \& PALMER, J. M. Phylogenetic Relationships between the families of recent Thysanoptera. Zoological Journal of the Linnean Society of London, 1980. v. 69, p. 111 - 141.

PETERS, W.; LATKA, I. Electron microscopic localization of chitin using colloidal gold labelled with wheat germ agglutinin. Histochemistry. 1986. V. 84, n. 2, p. 155-160. 
PIMENTEL, A.C.; FUZITA, F.J.; PALMISANO, G.; FERREIRA, C.; TERRA, W.R. Role of cathepsins $D$ in the midgut of Dysdercus peruvianus. Comparative Biochemistry and Physiology Part B: Biochemistry \& Molecular Biology. 2017. V. 204, p. 45-52.

RAIKITOV, R. A. The covering formed by brochosomes on the cuticle of leafhoppers (Homoptera, Cicadellidae). Entomological Review. 1995. V. 74. p. 90-103.

RAIKITOV, R. A. Secretory products of the Malpighian tubules of Cicadellidae (Hemiptera, Membracoidea): an ultrastructural study. International Journal of Insect Morphology and Embryology. 1999. V. 28, p. 179-193.

REGER, J. F. Fine structure of the surface coat of midgut epithelial cells in the homopteran Phyloscellis atra (Fulgorid). Journal Submicroscopic Cytology. 1971. V. 3. p. 353-358.

RESH, V. H.; CARDÉ, R. T. Encyclopedia of insects. Amsterdam, Boston: Academic Press, 2003. p. 66-74.

REYNOLDS, E. S. The use of lead citrate at high $\mathrm{pH}$ as an electron-opaque stain in electron microscopy. Journal of Cell Biology. 1963. V. 17. p. 208-212.

RHODES, J. D.; CROGHAN, P. C.; DIXON, F. G. Dietary sucrose and oligosaccharide synthesis in relation to osmoregulation in the pea aphid, Acyrthosiphon pisum. Physiological Entomology. 1997. V. 22. p. 373-379.

ROSSETI, V.; GARNIER, M. B.; GARNIER, J. M.; BERETTA, M. J. G.; TEIXEIRA, A. R. R.; QUAGGIO, J. A.; DE NIGRI, D. Presénce de bactéries dans le xyléme d'orangers attaints de chorose variegée, une nouvelle maladie des agrumes au Brésil. Paris: C.R.S. l'Académie des Sciences. 1990. V. 3. p. 345-349.

ROTHMAN, J. E. ; ORCI, L. Molecular dissection of the secretory pathway. Nature. 1992. V. 335. p. 409-415.

RUPERT, E. E. ; BARNES, D. R. Zoologia dos invertebrados. São Paulo. Rocca, $6^{\text {a }}$ ed. 1996. p. 1029.

SILVA, C. P.; RIBEIRO, A. F.; GULBENKIAN, S.; TERRA, W. R. Organization, origin and function of the outer microvillar (perimicrovillar) membranes of Dysdercus peruvianus (Hemiptera) midgut cells. Journal of Insect Physiology. 1995. V. 41, i. 12, p. 1093-1103. 
SILVA, C. P.; RIBEIRO, A. F.; TERRA, W. F. Enzyme markers and isolation of the microvillar and perimicrovillar membranes of Dysdercus peruvianus (Hemiptera: Pyrrhocoridae) midgut cells. Insect Biochemistry and Molecular Biology. 1996. V. 26 , n. 10 , p. 1001-1018.

SILVA, C. P.; SILVA, J. R.; VASCONCELOS, F. F.; PETRESKI, M. D. A.; DAMATTA, R. A.; RIBEIRO, A. F.; TERRA, W. R. Occurence of midgut perimicrovillar membranes in paraneopteran insect orders with comments on their function and evolutionary significance. Arthropod Structure and Development. 2004. V. 33, p. 139-148.

SHAKESBY, A. J.; WALLACE, I. S.; ISAACS, H. V.; PRITCHARD, J.; ROBERTS, D. M.; DOUGLAS, A. E. A water-specific aquaporin involved in aphid osmoregulation. Insect Biochemistry and Molecular Biology. 2009, V. 39.

SPURR, A. R. A low-viscosity epoxy resin embedding medium for electron microscopy. Journal of Ultrastructure Research. 1969. v. 26, p.31-43.

STEFANINI, Mario; DE MARTINO, CESARE; ZAMBONI, Luciano. Fixation of ejaculated spermatozoa for electron microscopy. Nature. 1967. V. 216, n. 5111, p. 173.

TERRA, W. R. Physiology and biochemistry of insect digestion: an evolutionary perspective. Brazilian Journal of Medical and Biological Research. 1988. V. 21. p. 675-734.

TERRA, W. R. Evolution of digestive system of insects. Annual Review of Entomology. 1990. V. 35, p. 181-200.

TERRA, W. R. The origin and function of the insect peritrophic membrane and peritrophic gel. Arch Insect Biochem Physiol. 2001. V. 47. p. 47-61.

TERRA, W. R.; CRISTOFOLETTI, P. T. Midgut proteinases in three divergent species of Coleoptera. Comparative Biochemistry and Physiology. 1996. V. 113(B). p. 725730.

TERRA, W. R.; FERREIRA, C. Insect digestive enzymes: properties, compartmentalization and function. Comparative Biochemistry and Physiology. 1994. V. 109(B), p.1-62. 
TERRA, W. R.; FERREIRA, C.; BAKER, J. E. Compartmentalization of digestion. In: LEHANE, M. J.; BILLINGSLEY, P. F. Biology of the insect midgut. London: Chapman and Hall, 1996a. p.206-235.

TERRA, W. R.; FERREIRA, C.; JORDÃO, B. P.; DILLON, R. J. Digestive enzymes. In: LEHANE, M. J., BILLINGSLEY, P. F. Biology of the insect midgut. London: Chapman and Hall, 1996b. p.154-194.

TERRA, W. R.; FERREIRA, C. Biochemistry and molecular biology of digestion. In: GILBERT, L. I. Insect molecular biology and biochemistry. Elsevier. 2012. p. 365418.

TRIPLEHORN, C. A.; JOHNSON, N. F. Borror and Delong's introduction to the study of insects. $7^{\text {th }}$ ed. Thomson Brooks/Cole, 2005. p.1-4, 672-673, 737-774.

TSAI, James H.; PERRIER, Joan L. Morphology of the digestive and reproductive systems of Peregrinus maidis (Homoptera: Delphacidae). Florida Entomologist. 1993. p. 428-436.

TSAI, J. H.; PERRIER, J. L. Morphology of the digestive and reproductive systems of Dalbulus maidis and Graminella nigrifrons (Homoptera: Cicadellidae). Florida Entomologist. 1996. V. 79, n. 4, p. 563-78.

Ullman, D. E., Westcot, D. M., Hunter, W. B., \& Mau, R. F. Internal anatomy and morphology of Frankliniella occidentalis (Pergande) (Thysanoptera: Thripidae) with special reference to interactions between thrips and tomato spotted wilt virus. International Journal of Insect Morphology and Embryology. 1989. V. 18, n. 5-6, p. 289-310.

UTIYAMA, A. H. Estudo morfofuncional do sistema digestivo da cigarrinha Bucephalogonia xanthophis (Hemiptera: Cicadellidae). Dissertação (Mestrado em Genética/Biologia), Universidade de São Paulo, São Paulo, 2011.

UTIYAMA, A. H. Estudo comparativo da organização morfofuncional do intestino médio de espécies representativas da ordem Hemiptera. Tese (Doutorado em Biologia/Genética), Universidade de São Paulo, 2016.

UTIYAMA, A. H.; TERRA, W.R.; RIBEIRO, A.F. The digestive system of the leafhopper Bucephalogonia xanthophis (Hemiptera, Cicadellidae): the organization of the 
luminal membrane complex. Journal of the Entomological Results. 2016. V. 40, n. 4, p. 339-346.

WIGGLESWORTH, V. B. The principles of insect physiology. $7^{\text {th }}$ ed. London: Chapman and Hall, 1972. p.476-552.

${ }^{1}$ De acordo com a Associação Brasileira de Normas Técnicas (ABNT NBR 6023). 
Figuras 
Figura 1 - Representação esquemática do sistema digestivo da espécie Mahanarva fimbriolata.

E - Esôfago; $C F$ - Câmara de filtração; DC - Domínio cônico; $D T$ - Domínio tubular; IP - Intestino posterior; TM - Túbulos de Malpighi; $R$ - Reto. 


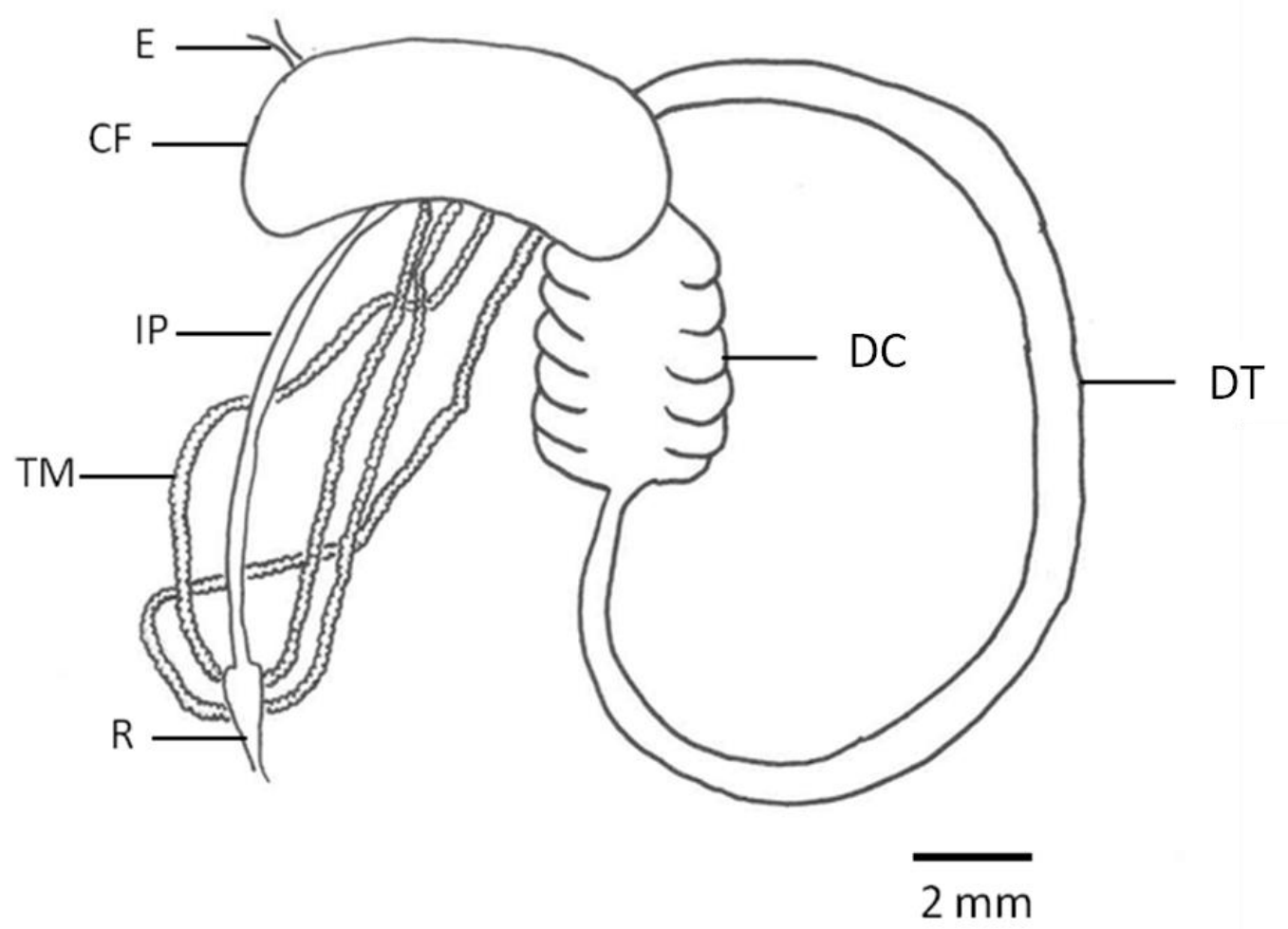


Figura 2 - Imagens histológicas de M. fimbriolata.

A - Câmara de filtração. É possível observar os diferentes tecidos em contato nessa região;

B - Domínio cônico do IM. Observe as invaginações do epitélio;

C - Domínio tubular do IM;

D - Região do piloro. O interior da estrutura é revestido por quitina (ponta de seta), devido a sua origem dérmica.

$D C$ - Domínio cônico do IM; $P$ - Piloro; TM - Túbulos de Malpighi; $L$ - Luz do IM. 

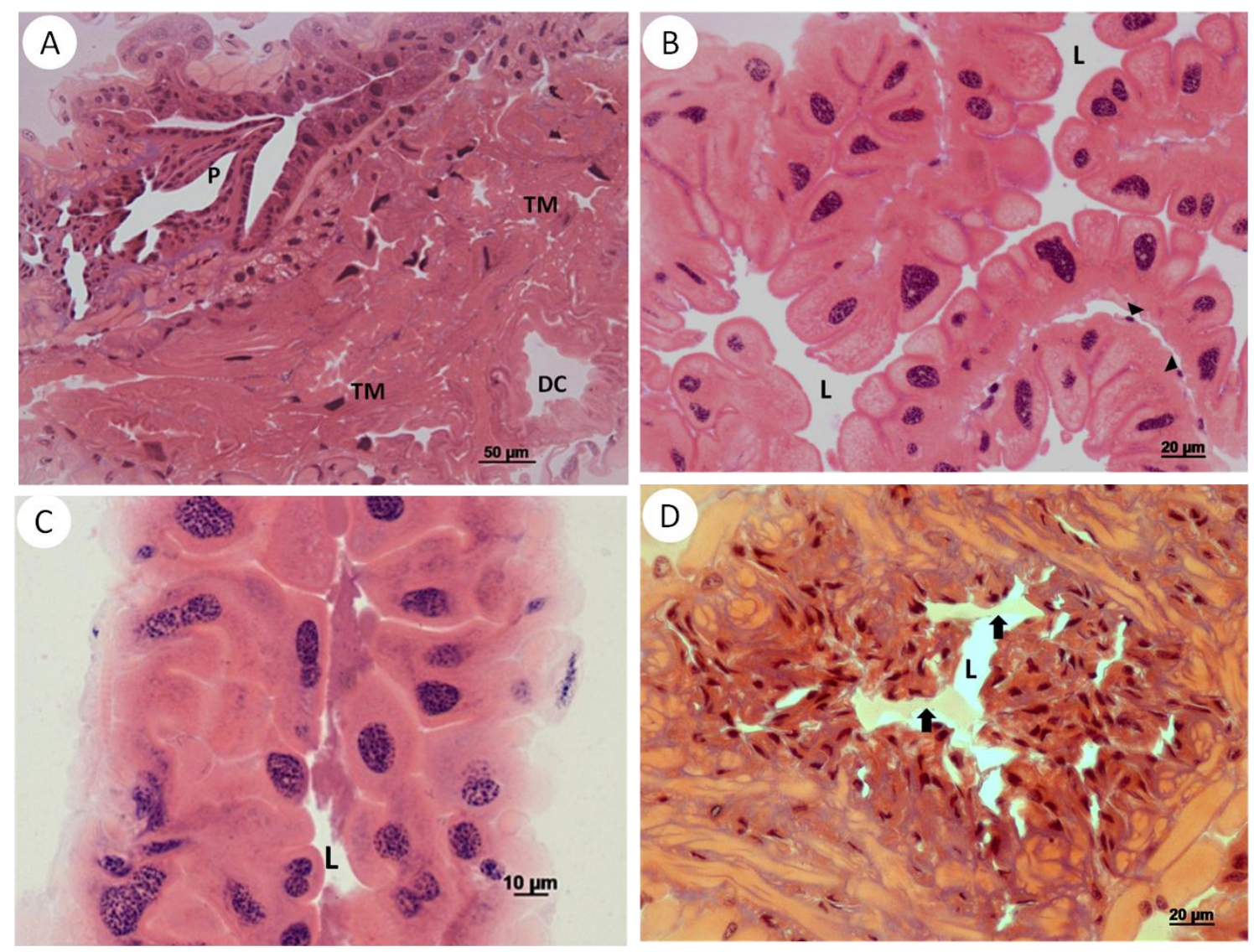
Figura 3 - Ultraestrutura da câmara de filtração de M. fimbriolata.

A - Células do intestino médio no interior da câmara de filtração. É possível notar as diferenças estruturais entre enterócitos e células dos TM. Os enterócitos apresentam invaginações da membrana plasmática basal (IT) em formato tubular, enquanto as células dos TM, lamelar.

B - Detalhe de células dos túbulos de Malpighi, com características semelhantes às observadas em "A", com invaginações da membrana plasmática basal de aspecto lamelar e microvilosidades curtas.

C - Detalhe da membrana plasmática basal dos enterócitos de $M$. fimbriolata, evidenciando as invaginações e aberturas à lâmina basal (seta).

$M v$ - Microvilosidades; $M i$ - Mitocôndrias; IT - Invaginações tubulares da membrana plasmática basal; IL - Invaginações lamelares da membrana plasmática basal; $L$ - Lúmen; Setas - Aberturas para a lâmina basal. 


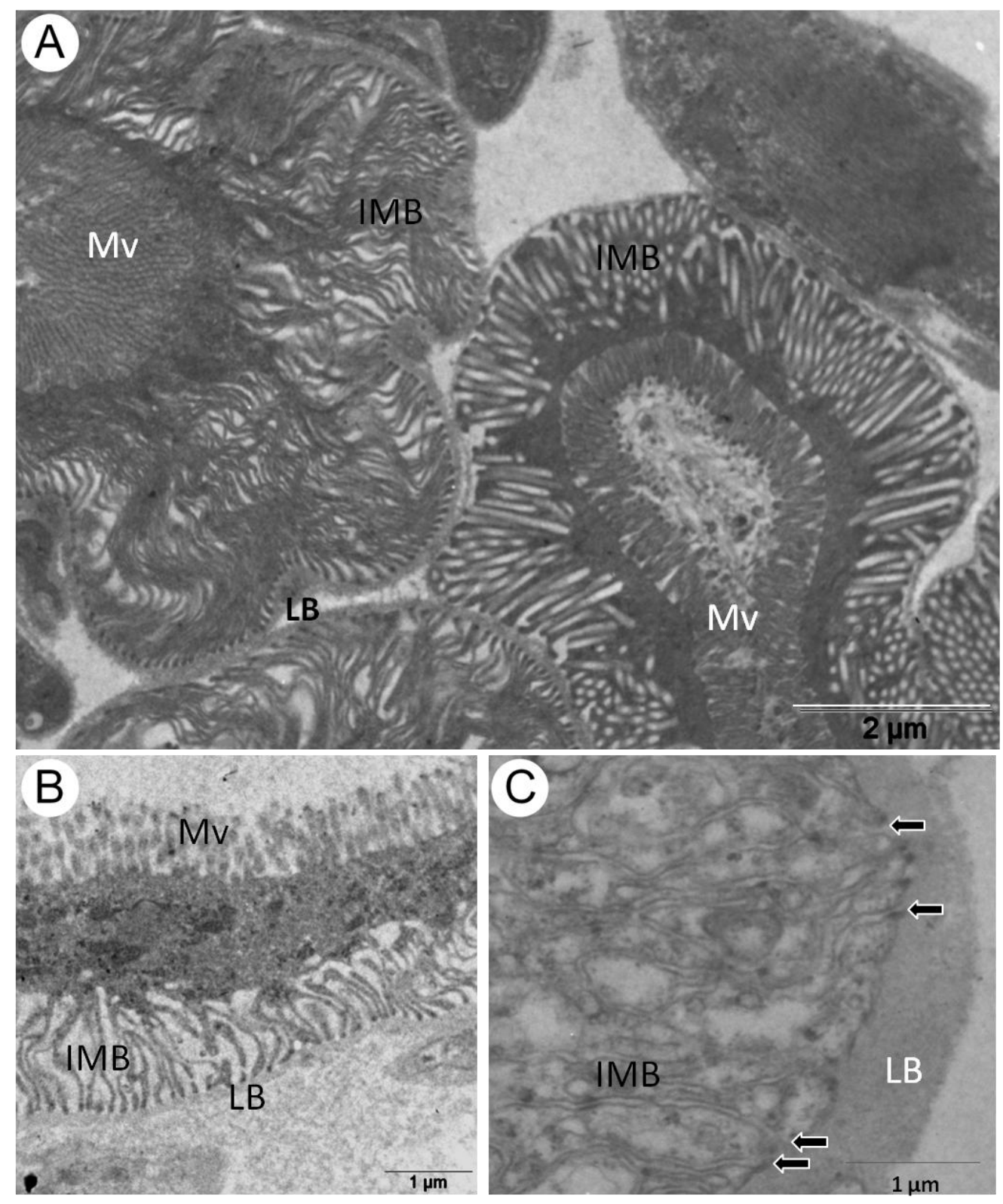


Figura 4 - Imagem ultraestrutural da região apical dos enterócitos de $M$. fimbriolata.

A - Detalhe dos enterócitos do DC, evidenciando a presença de organelas da rota secretora próximas às bases das microvilosidades.

B - Detalhe dos enterócitos do DT, mostrando grande similaridade com o encontrado em DC.

$M v$ - Microvilosidades; $M I$ - Mitocôndrias; $V$-Vesículas; $G$ - Áreas de Golgi. 

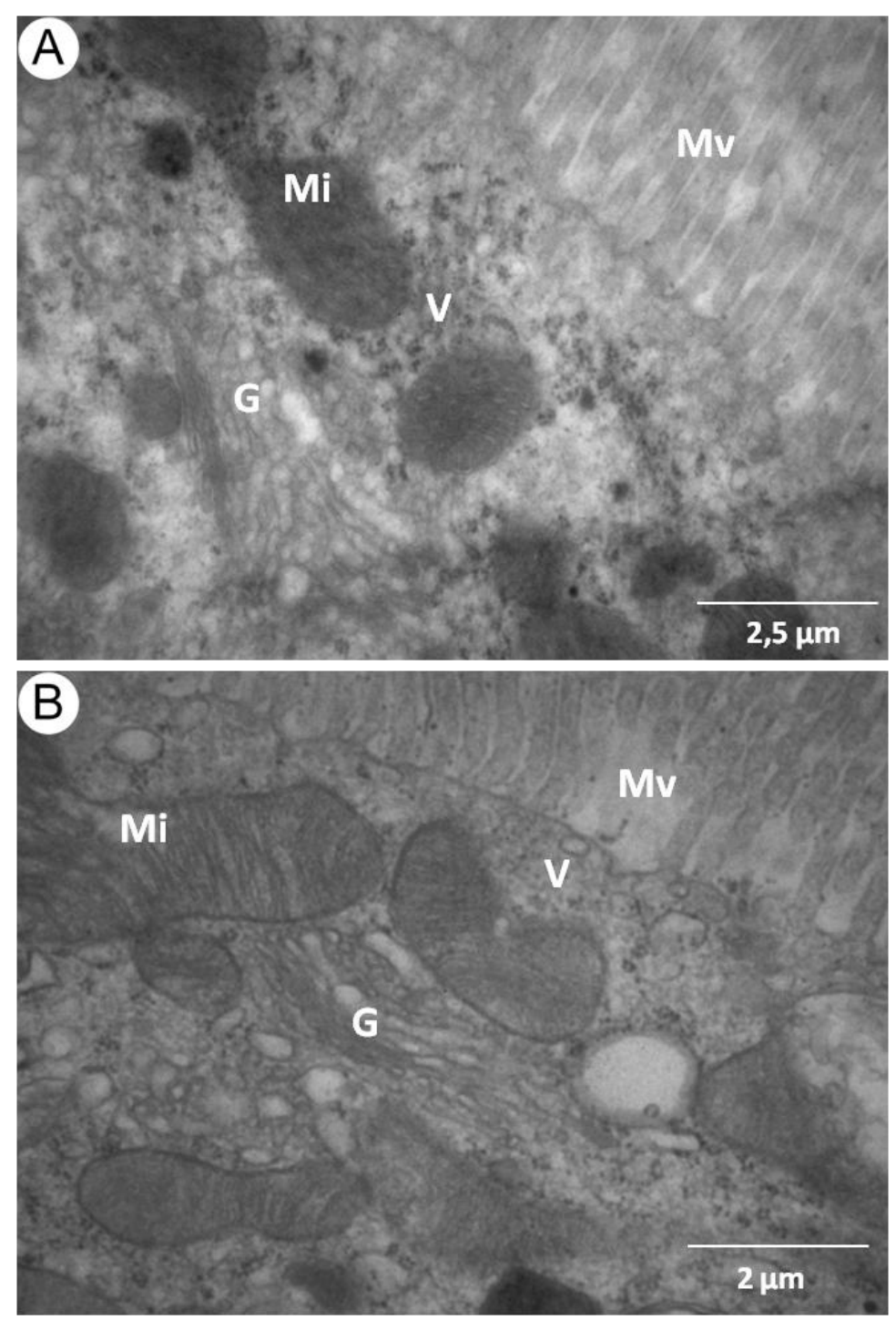
Figura 5 - Ultraestrutura das membranas luminais em forma de chama associadas às microvilosidades dos enterócitos de $M$. fimbriolata.

A - Visão geral, mostrando as membranas luminais em forma de chama (MLC) associadas às extremidades das microvilosidades (Mv) e se projetando ao lúmen.

B - Detalhe da organização das membranas, que sugere a formação de compartimentos fechados.

C - Detalhe das microvilosidades dos enterócitos. Observam-se vesículas que se originam a partir de constrições do ápice das microvilosidades (setas).

$M v$ - Microvilosidades; $M L C$ - Membranas luminais em forma de chama; $L-$ Lúmen; Setas - Constrições das microvilosidades. 

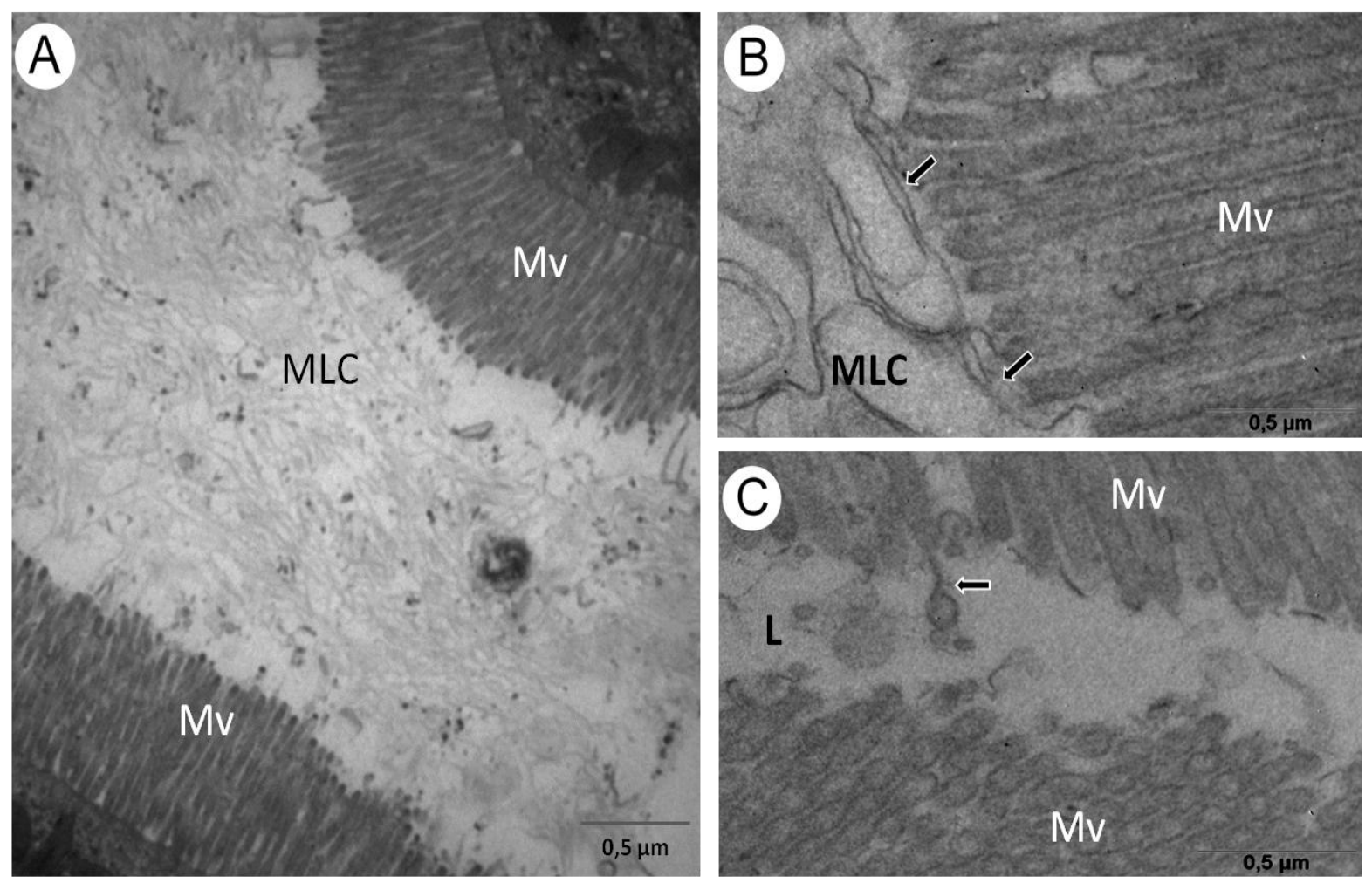
Figura 6 - Imagens ultraestruturais de MEV do IM de M. fimbriolata.

A - Visão geral do domínio cônico do IM. Os enterócitos que compõem o epitélio possuem suas bases estreitas e ápices mais largos, semelhante a cogumelos. É possível, ainda, notar as invaginações do epitélio.

B - Detalhe do ápice de um enterócito do DC. Note a película $(P)$ que reveste a célula.

C - Detalhe evidenciando as membranas que revestem os enterócitos, formando estruturas vesiculares $\left(^{*}\right)$.

D - Enterócito com fratura apical, exibindo as microvilosidades e organelas presentes no interior da célula.

E - Detalhe das microvilosidades e película membranosa $(P)$ que as revestem.

$M v$ - Microvilosidades; $L$ - Lúmen; $P$ - Película. 

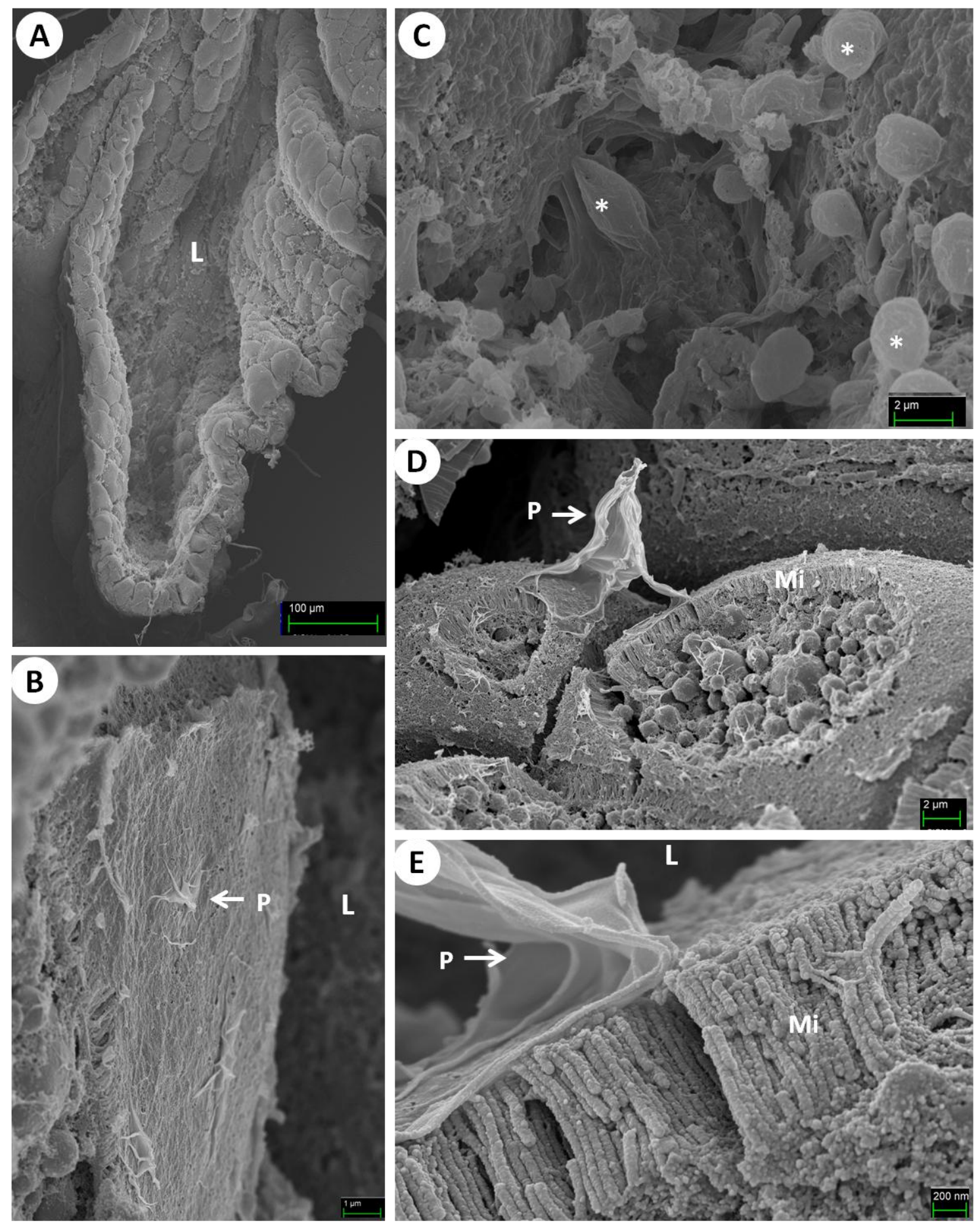
Figura 7 - Esquema da organização do complexo luminal de membranas de M. fimbriolata na forma de MLC. As membranas são formadas a partir da constrição e posterior alongamento do ápice das microvilosidades, que se projetam para o lúmen.

$M v$ - Microvilosidades; $M L C$ - membranas luminais em forma de chama. 


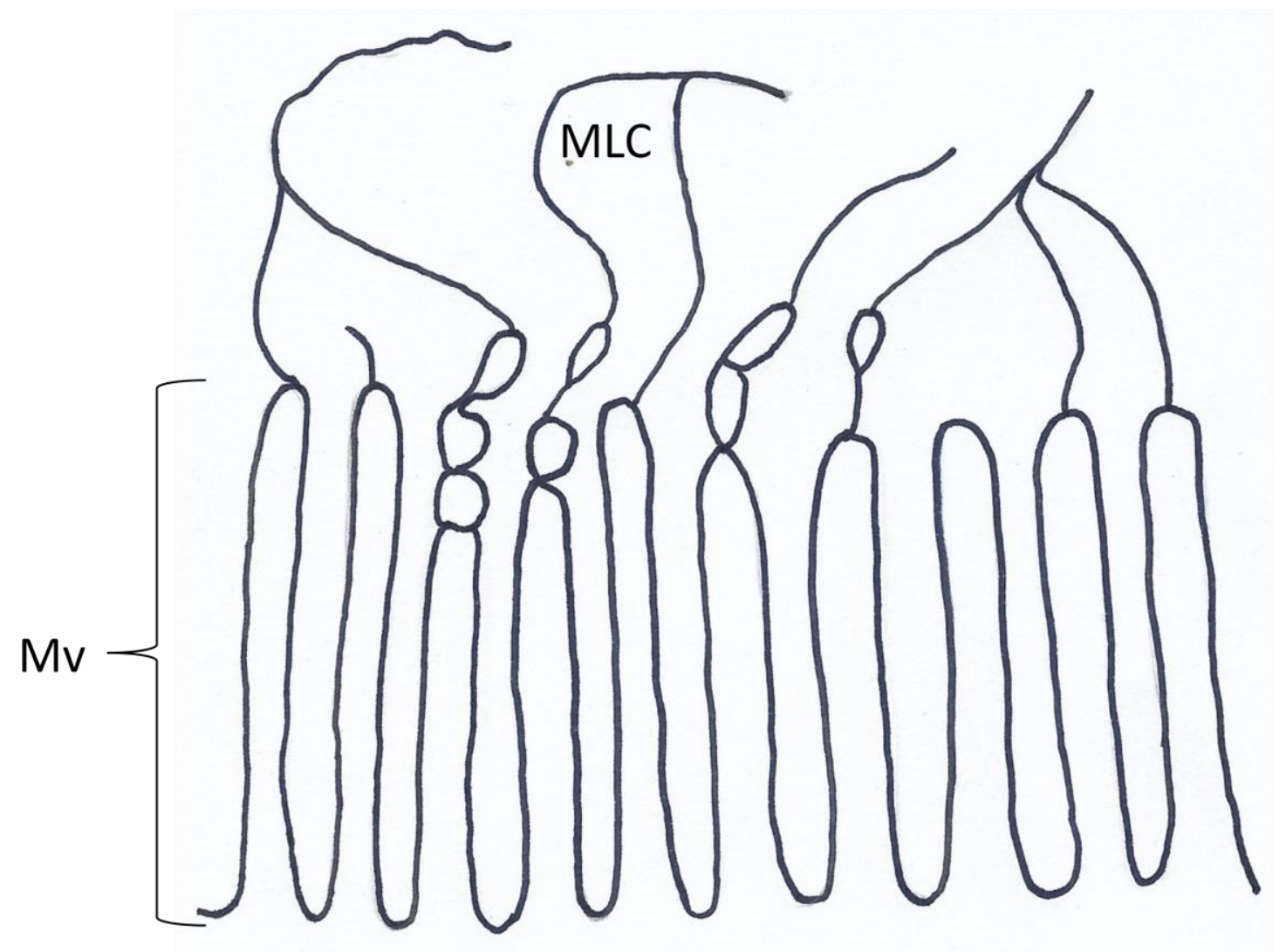


Figura 8 - Representação esquemática do sistema digestivo da espécie Dalbulus maidis.

E - Esôfago; CF - Câmara de filtração; DC - Domínio cônico; DT - Domínio tubular; IP - Intestino posterior; TM - Túbulos de Malpighi; $R$ - Reto. 


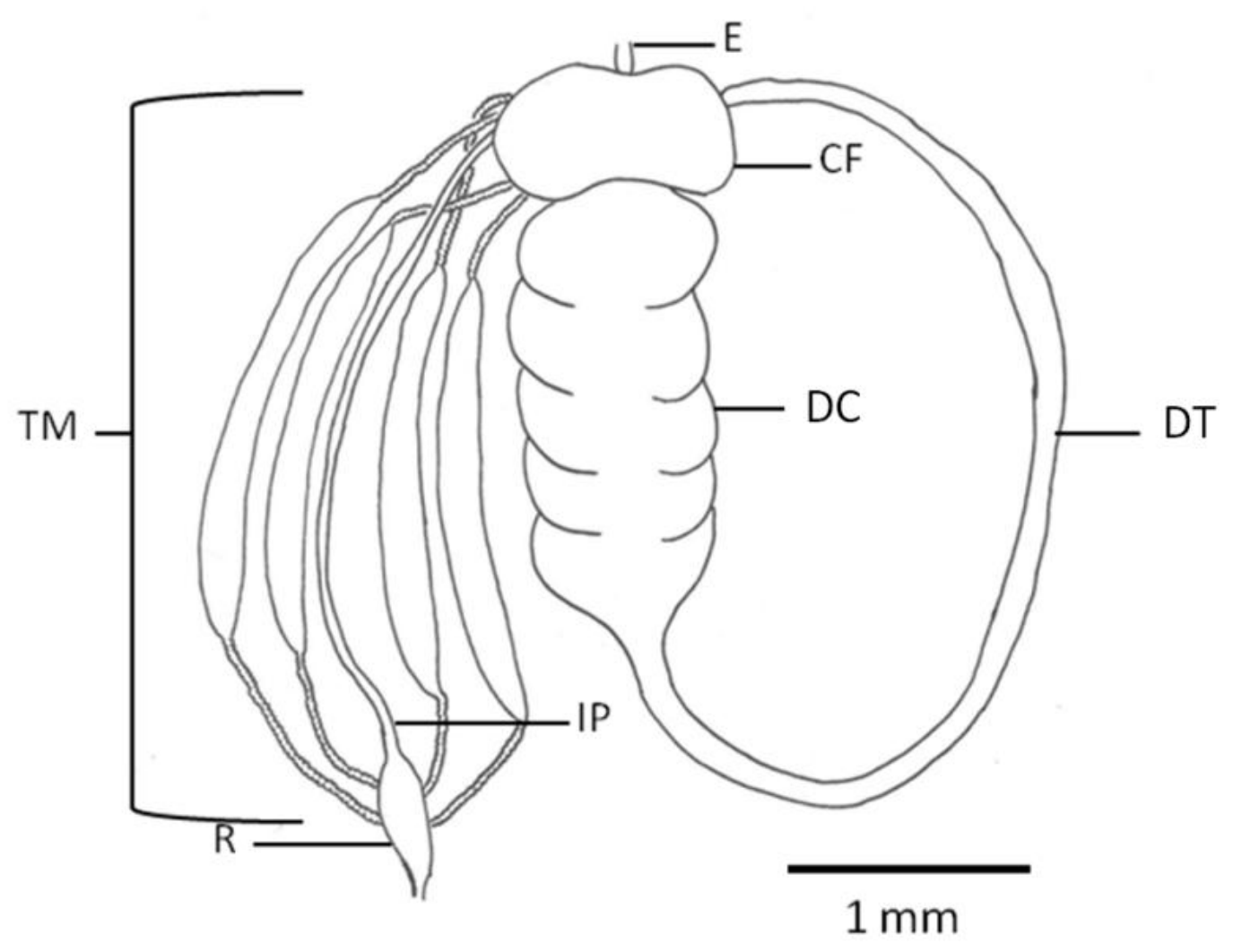


Figura 9 - Imagens histológicas de D. maidis.

A - Vista geral do intestino médio. É possível verificar a CF, o DT em corte transversal e os TM enovelados ao redor do órgão. Notar a presença de invaginações do domínio cônico (seta)

B - Detalhe da CF, evidenciando os diferentes tecidos constituintes.

C - Aspecto histológico de um dos quatro TM. Os TM da espécie possuem uma região expandida em sua porção central (RE) que se diferencia das regiões proximais $(\mathrm{RP})$ e distais do túbulo.

$T M$ - túbulos de Malpighi; DT - domínio tubular do intestino médio; CF câmara de filtração; $T M$ - túbulos de Malpighi; $D C$ - domínio cônico do intestino médio; $L$ - luz do intestino; $R E$ - Região expandida do TM; $R P$ Região posterior do TM. 

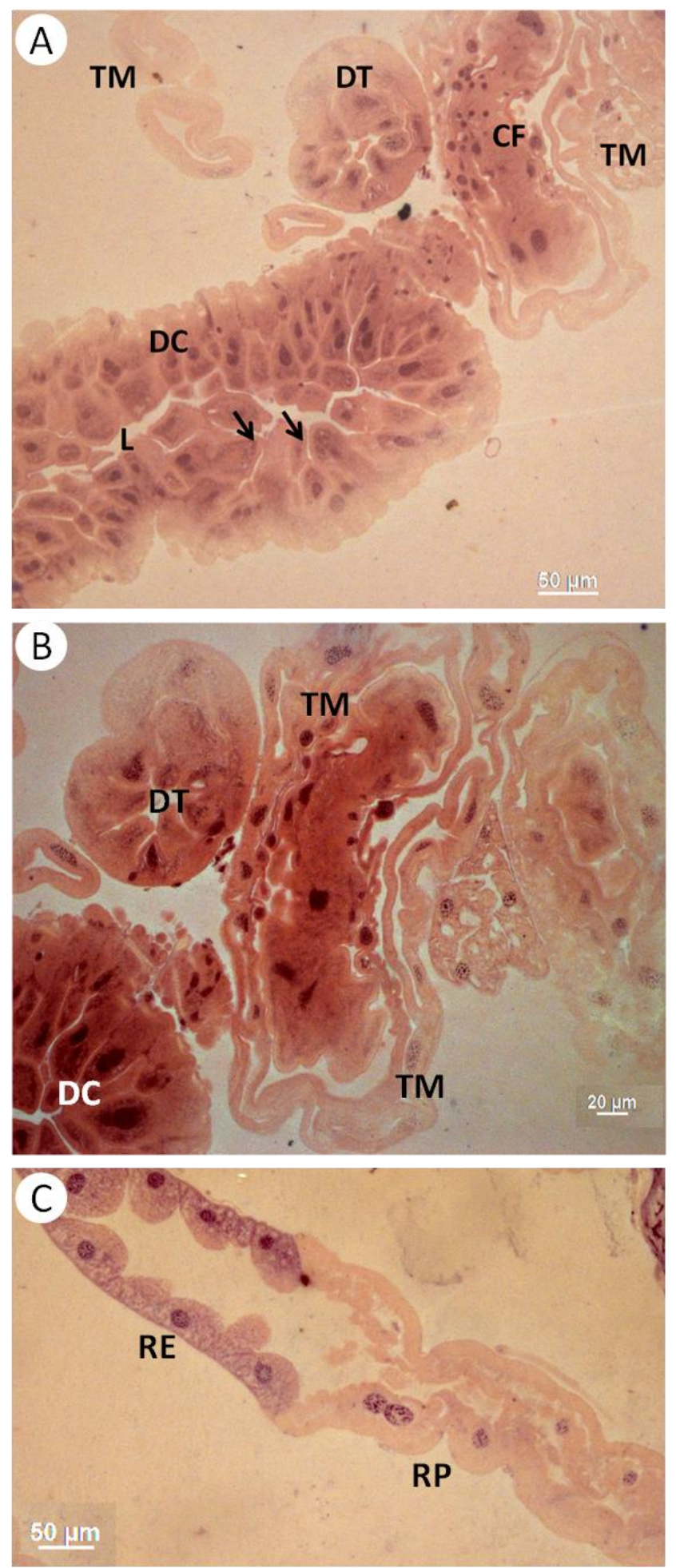
Figura 10 - Ultraestrutura (MET) dos enterócitos de D. maidis.

A - Vista geral dos enterócitos do IM. Observe a grande quantidade de mitocôndrias na base das microvilosidades. Note também a organização das MLC, formando, aparentemente, compartimentos fechados no lúmen do IM.

B - Detalhe da região apical de um enterócito, evidenciando a presença de um retículo endoplasmático abundante.

C - Detalhe das microvilosidades em corte transversal. É possível notar que as microvilosidades não são revestidas individualmente por membranas, como no modelo MPM de complexo luminal.

D - Detalhe da organização do MLC, evidenciando os compartimentos formados pelas membranas que se projetam para o lúmen a partir das microvilosidades.

E - Detalhe da lâmina basal evidenciando as aberturas das invaginações da membrana plasmática basal (setas).

$M v$ - Microvilosidades; $M L C$ - Membranas luminais em forma de chama; RE Retículo endoplasmático; $L$ - Lúmen; $L B$ - Lâmina basal; IMB - Invaginações da membrana plasmática basal. 


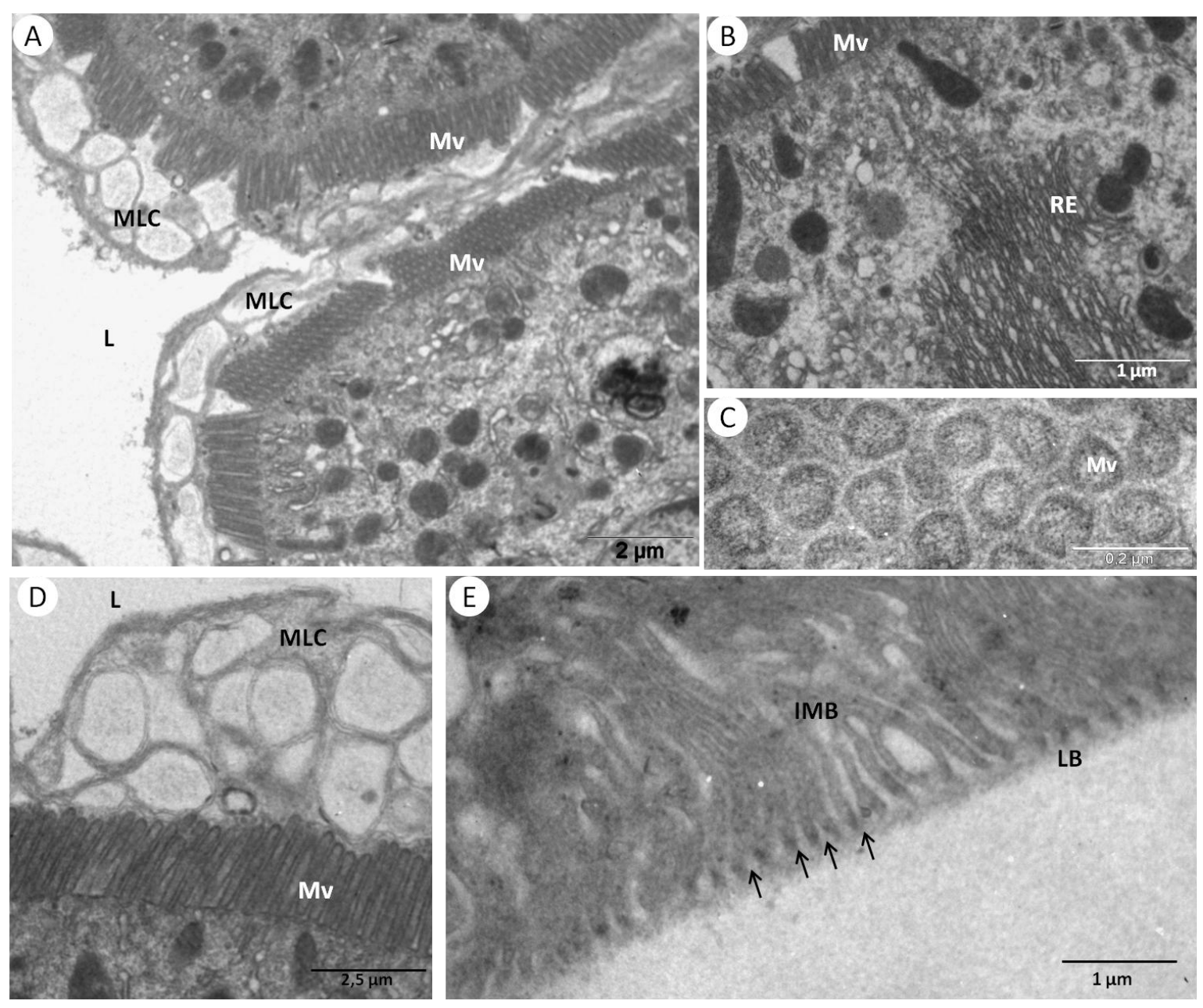


Figura 11 - Imagens ultraestruturais (MEV) de D. maidis.

A - Vista geral do sistema digestivo de $D$. maidis em corte longitudinal, exibindo o interior do DC e parte da CF.

B, C - Detalhe do domínio cônico do IM, comparando uma imagem de MEV (B) com uma histológica de região equivalente (C).

D - Detalhe da superfície dos enterócitos. É possível observar que os enterócitos de $D$. maidis são revestidos por uma película membranosa (seta).

$D C$ - Domínio cônico; $C F$ - Câmara de filtração; $D T$ - Domínio tubular; $L$ lúmen do IM. 

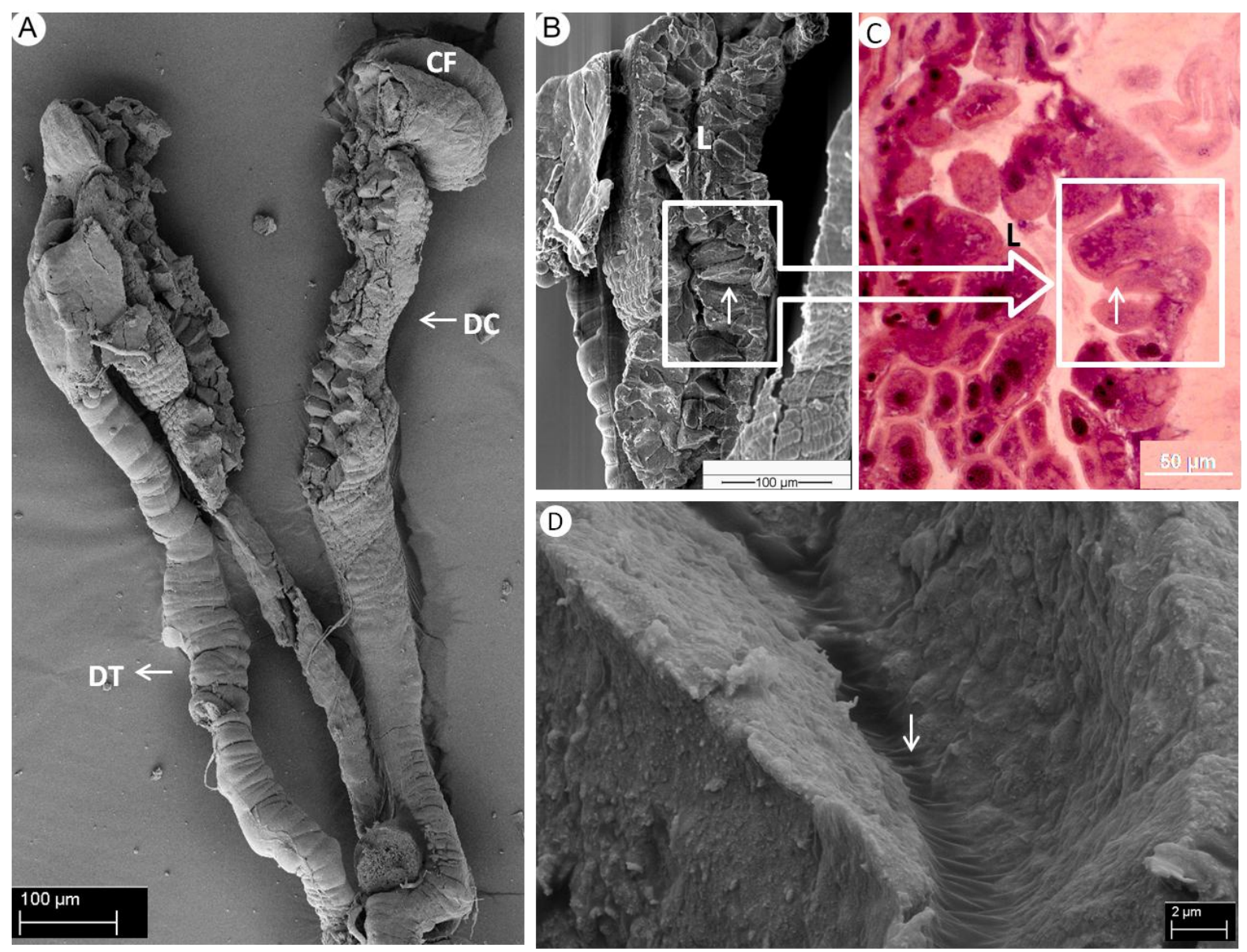
Figura 12 - Ultraestrutura dos TM de D. maidis.

A - Imagens ultraestruturais de MET. Observe as invaginações lamelares da membrana plasmática basal, as microvilosidades curtas e os brocossomos na luz do tubo.

B - Detalhe da região secretora dos TM. Note a presença de brocossomos (B), na forma de estruturas estrelares na luz do tubo e de bactérias (bac), comuns no bolo alimentar.

C - Imagens ultraestruturais de MEV. À esquerda da imagem observase a região secretora do TM (TMs) e à direita, a região distal do túbulo (TMd).

D - Detalhe da luz da região secretora do TM.

Mv - Microvilosidades; L - Lúmen; IMB - Invaginações da membrana plasmática basal; TMs - Túbulo de Malpighi secretor; TMd - Túbulo de Malpighi distal 


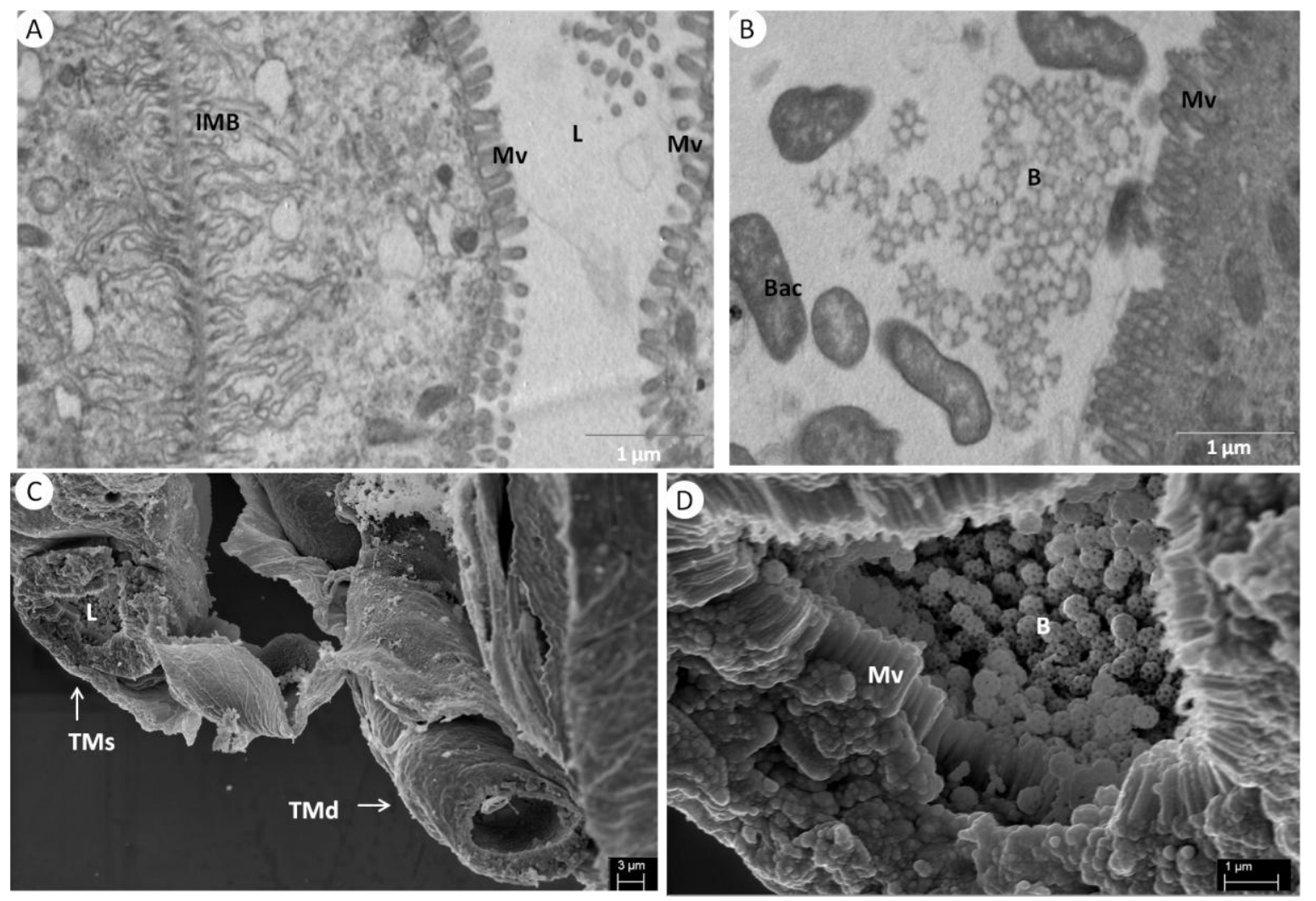


Figura 13 - Esquema da organização do complexo luminal de membranas de D. maidis. As membranas são formadas a partir do ápice das microvilosidades, projetam-se ao lúmen e unem-se na luz do tubo, formando o que parecem ser compartimentos fechados.

$M v$ - Microvilosidades; $M L C$ - Membranas luminais em forma de chama. 


$$
\text { का }
$$


Figura 14 - Imagens obtidas através de microscopia de fluorescência confocal de M. fimbriolata. Notar a intensa fluorescência $\left(^{*}\right)$ na região apical do epitélio correspondente à região do MLC.

A - Vista geral de fluorescência do intestino médio.

B - Imagem sobreposta de fluorescência e DIC (contraste diferencial de interferência), evidenciando o epitélio.

$L$ - lúmen. 

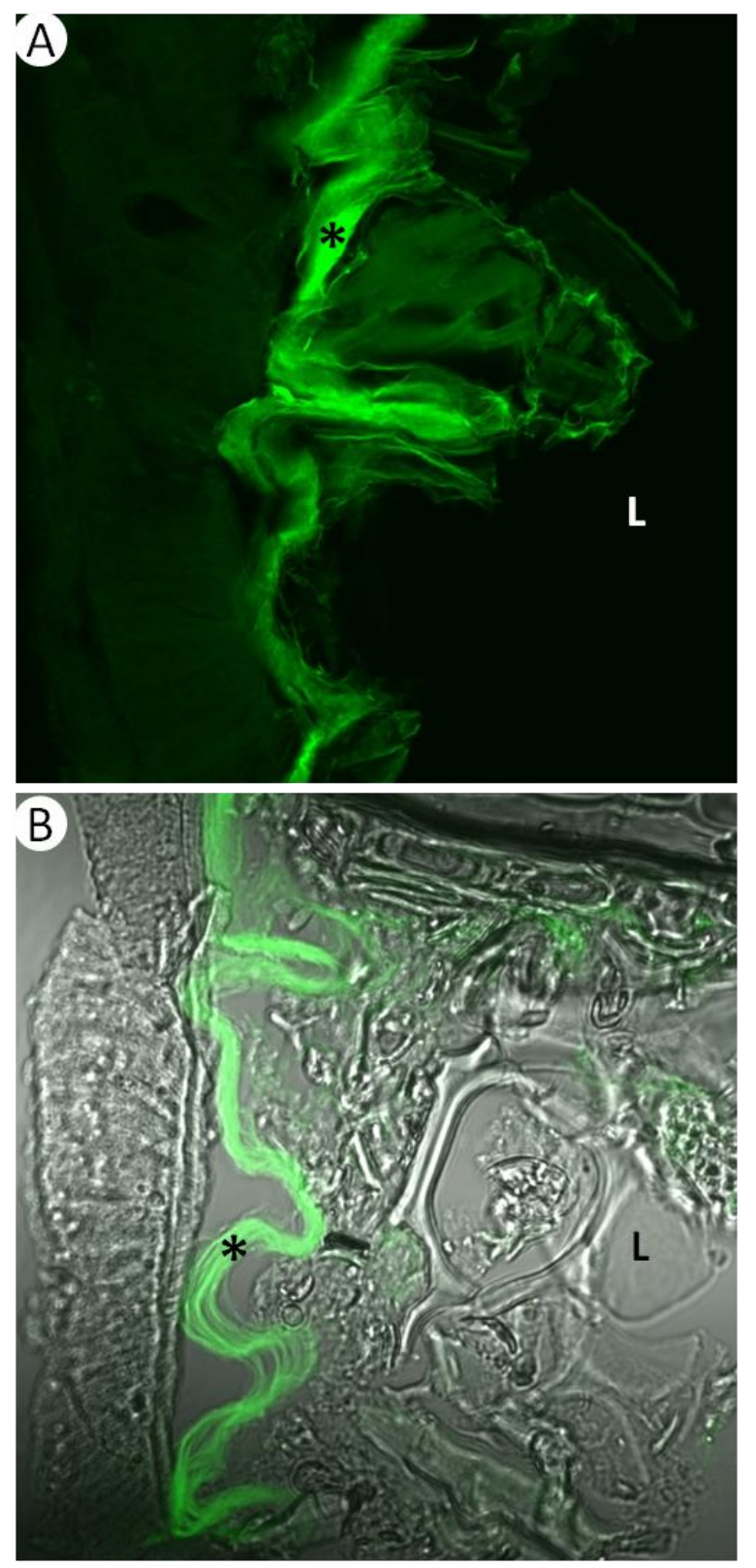
Figura 15 - Imagens obtidas através de microscopia de fluorescência confocal de $D$. maidis. Notar a intensa fluorescência $\left({ }^{*}\right)$ na região apical do epitélio correspondente à região do MLC.

A - Vista geral de fluorescência do intestino médio.

B - Imagem sobreposta de fluorescência e DIC (contraste diferencial de interferência), evidenciando o epitélio.

L-lúmen. 

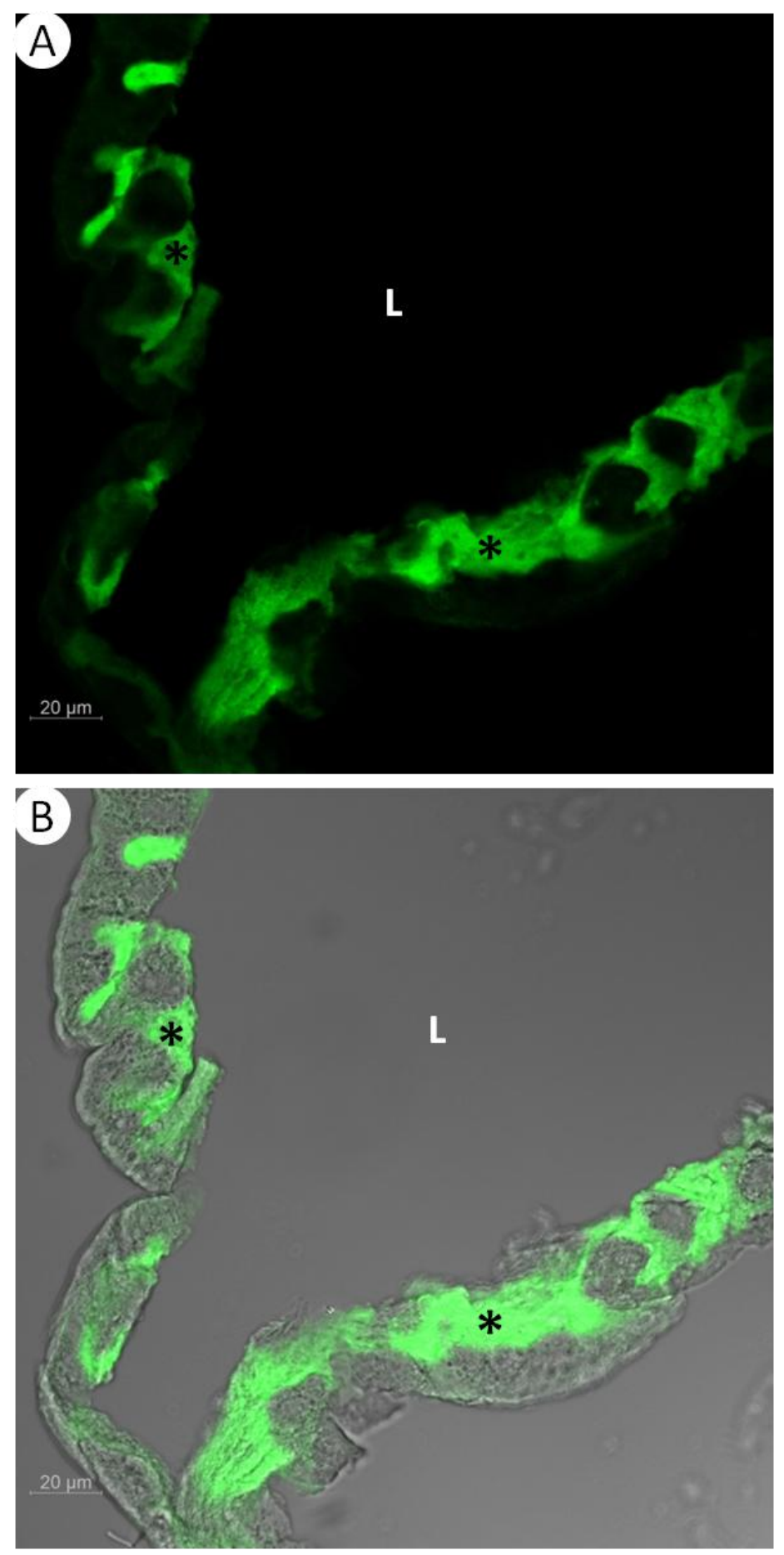
Figura 16 - Representação esquemática do sistema digestivo da espécie Peregrinus maidis.

IA - Intestino anterior; IM - Intestino médio; PI - Piloro; IP - Intestino posterior; TM - Túbulos de Malpighi. 


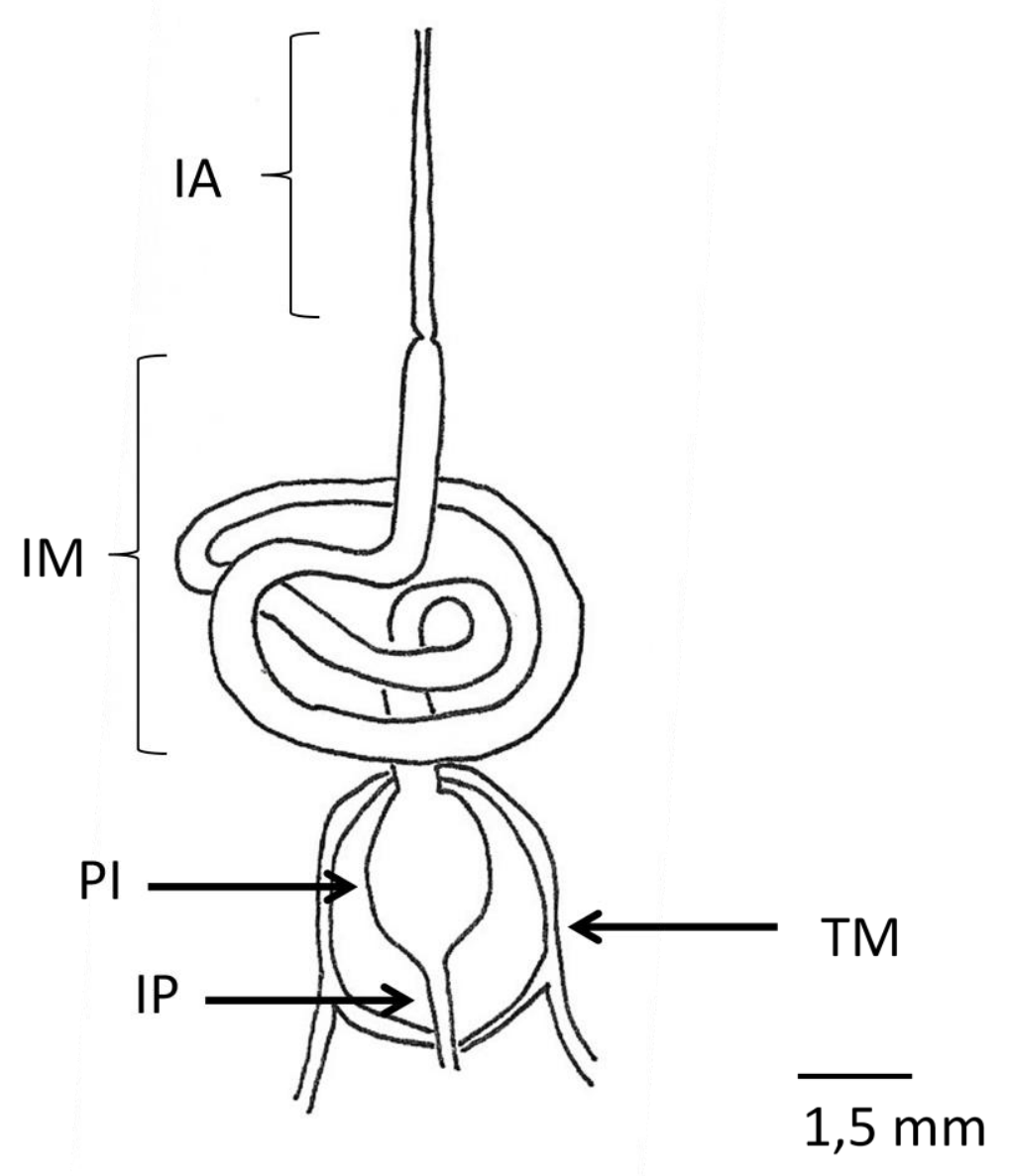


Figura 17 - Imagens ultraestruturais (MET) de $P$. maidis.

A - Região apical do enterócito de P. maidis. É possível observar as microvilosidades com o complexo luminal de membranas associado, na luz do tubo.

B - Região basal do enterócito. Note que as invaginações da membrana plasmática basal são estreitas e sem muitas aberturas à lâmina basal.

$C L M$ - Complexo luminal de membranas; $L$ - Lúmen; $M v$ - Microvilosidades; $M i$ - Mitocôndrias; IMB - Invaginações da membrana plasmática basal; $L B$ Lâmina basal. 

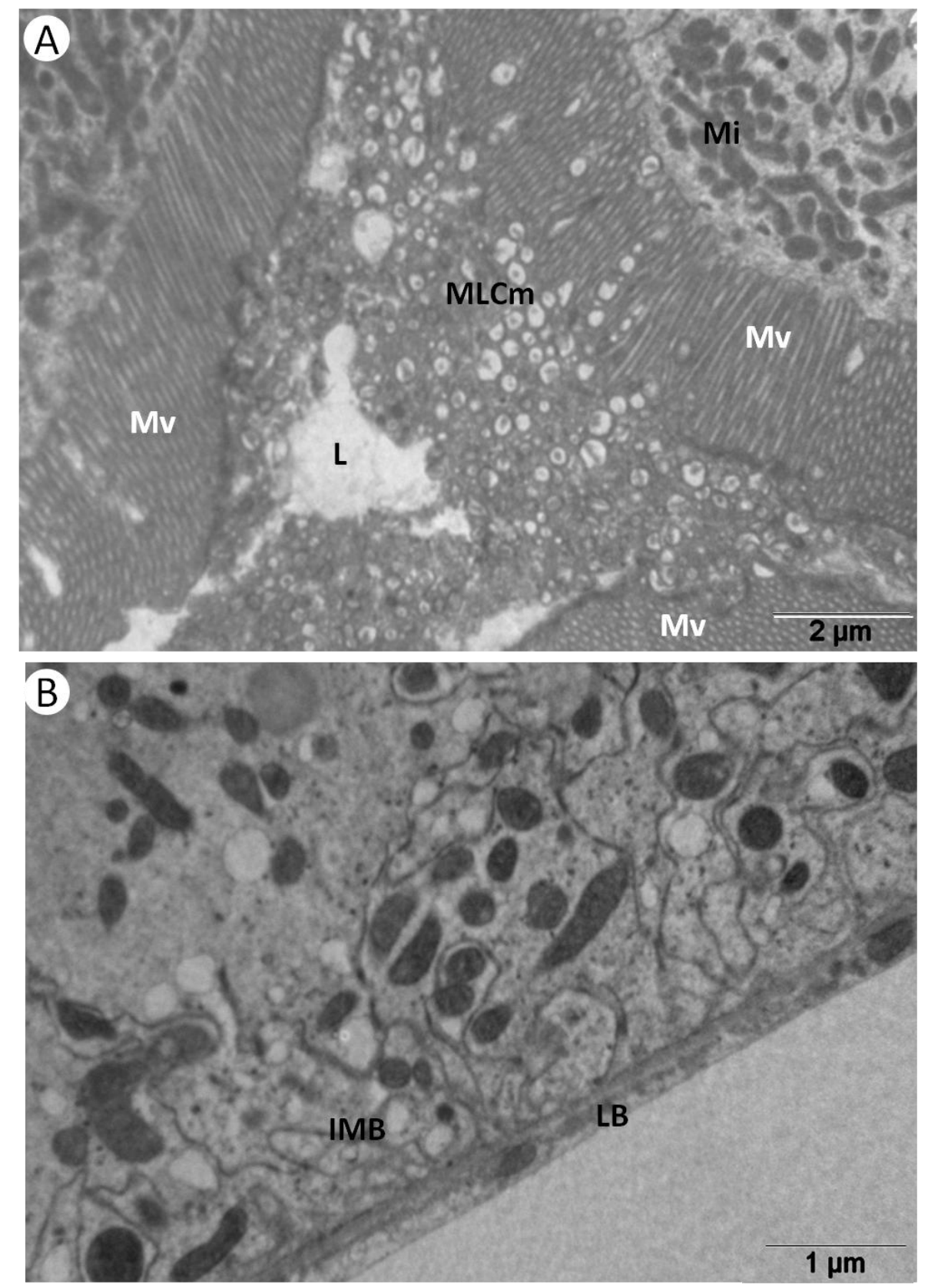
Figura 18 - Imagens ultraestruturais (MET) de $P$. maidis.

A - Detalhe da região apical do enterócito de $P$. maidis. Note que o complexo luminal de membranas forma uma camada eletrondensa junto ao ápice das microvilosidades.

B - Vista geral do enterócito, evidenciando a projeção de membranas do complexo luminal de membranas ao lúmen.

C - Detalhe da região basal do enterócito. Note que as invaginações da membrana plasmática basal são estreitas e sem muitas aberturas à lâmina basal.

MLCm - Membranas luminais em forma de chama modificadas; Mv Microvilosidades; $L B$ - Lâmina basal. 

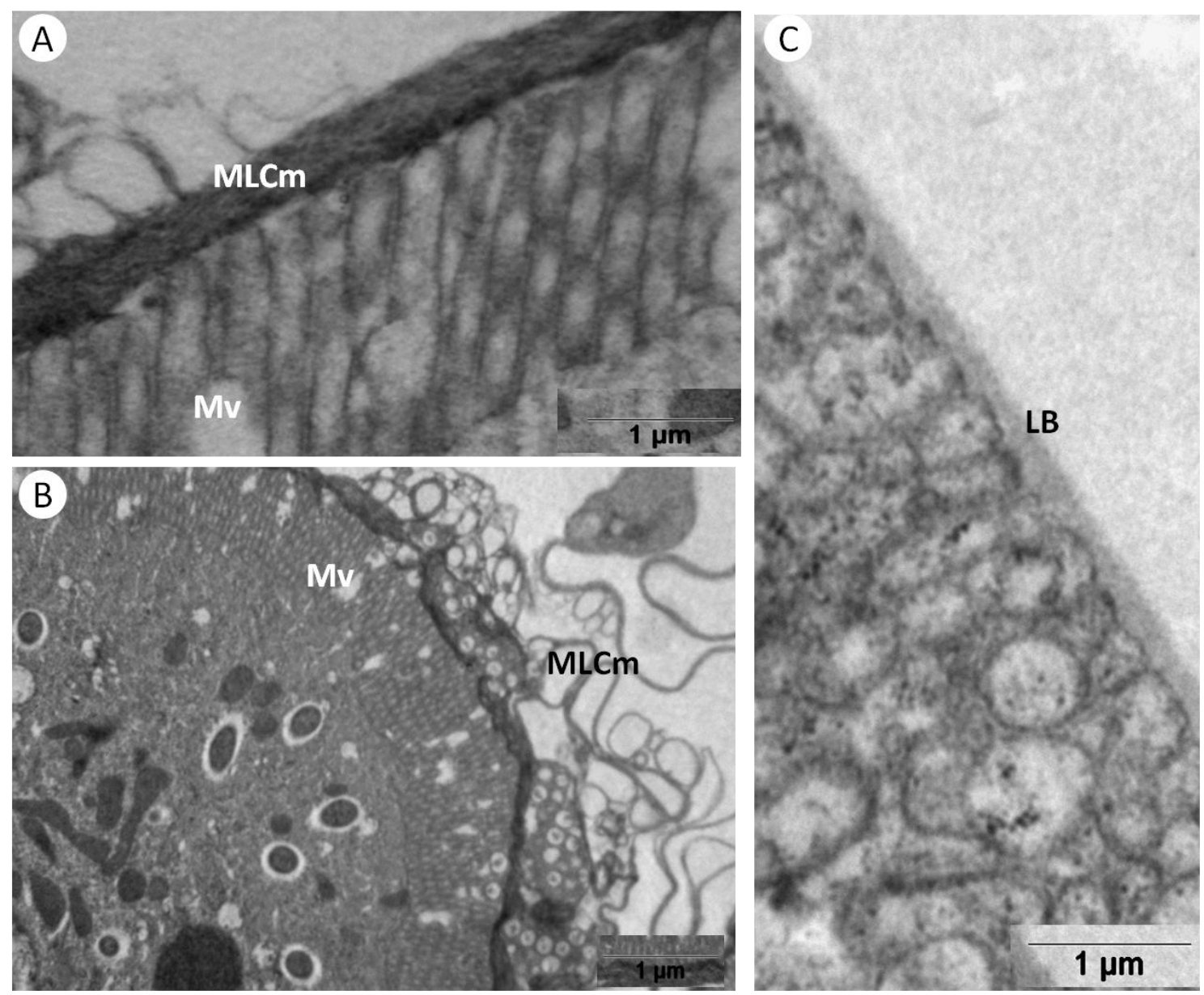
Figura 19 - Esquema da organização do complexo luminal de membranas de P. maidis

$M v$ - Microvilosidades; $M L C m$ - complexo luminal de membranas modificado. 


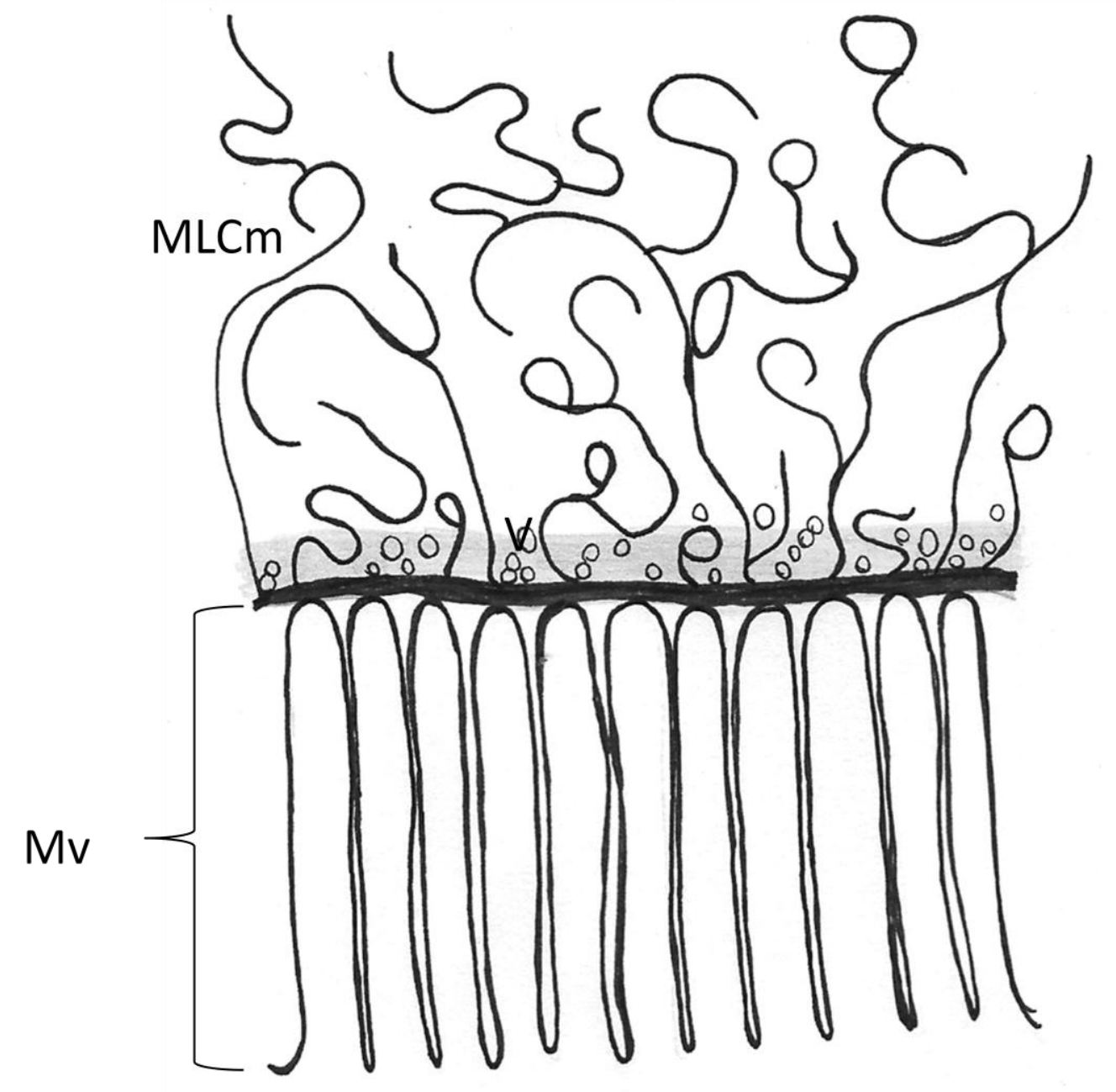


Figura 20 - Imagens ilustrativas de uma espécie estudada de Thysanoptera (Frankliniella schultzei) evidenciando o reduzido tamanho dos exemplares dessa ordem (A) e a consequente dificuldade de dissecção, dado o tamanho dos instrumentos utilizados (B). Seta: exemplar de F. schultzei. 


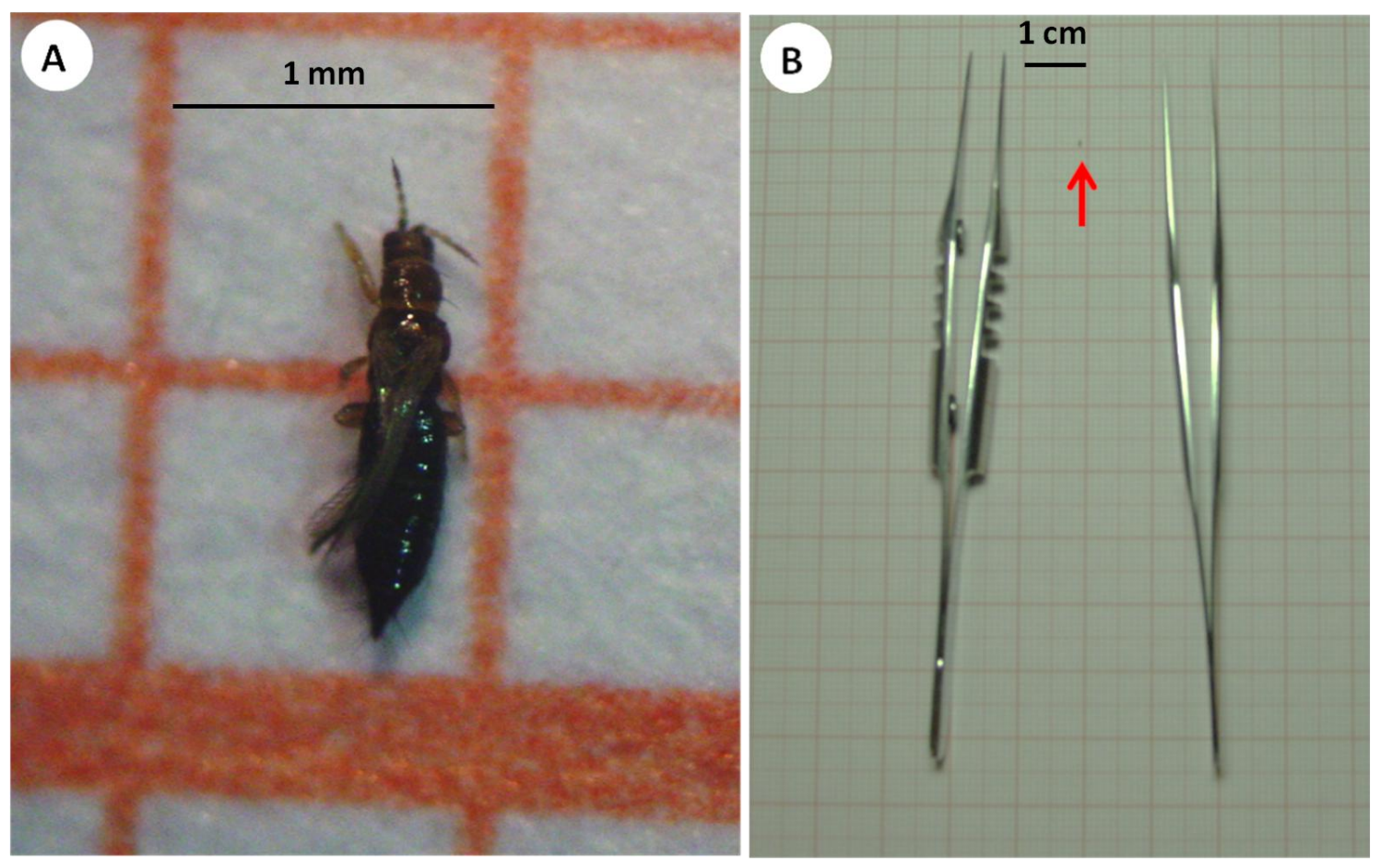


Figura 21 - Representação esquemática geral do sistema digestivo dos representantes estudados de Thysanoptera.

$I A$ - Intestino anterior; IM - Intestino médio; IP - Intestino posterior; TM Túbulos de Malpighi. 


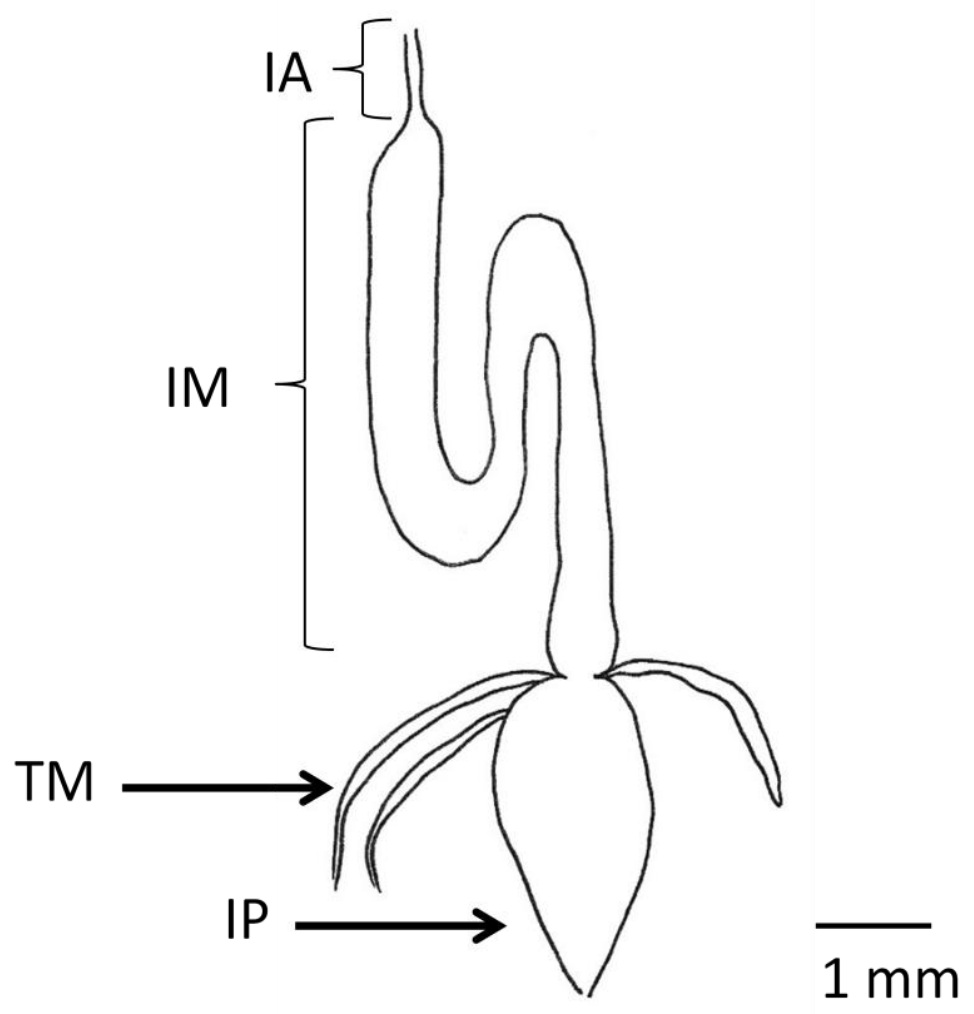


Figura 22 - Imagens ultraestruturais (MET) de F. schultzei.

A - Região apical dos enterócitos mostrando as microvilosidades.

B - Detalhe das microvilosidades evidenciando o complexo de membranas similar ao tipo MLC associado ao ápice das microvilosidades (setas).

C - Detalhe das microvilosidades em corte transversal.

D - Vista geral do citoplasma do enterócito.

L - Lúmen; Mv - Microvilosidades; Mi - Mitocôndrias; RE - Retículo endoplasmático. 

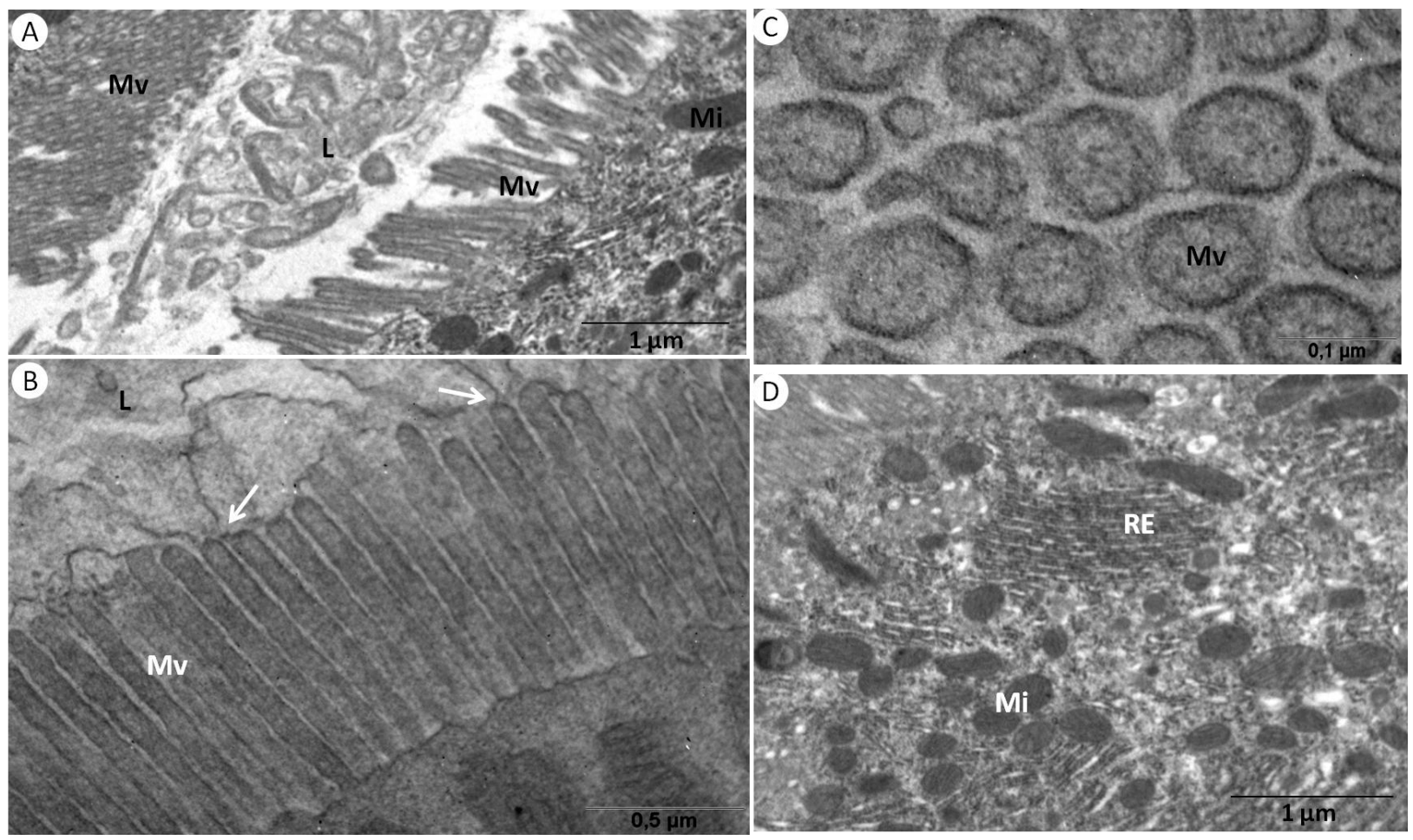
Figura 23 - Esquema da organização do complexo luminal de membranas de Franklinella schultzei. As membranas são formadas a partir do ápice das microvilosidades, projetam-se ao lúmen, organização semelhante ao MLC.

Mv - Microvilosidades; MLC - Membranas luminais em forma de chama 


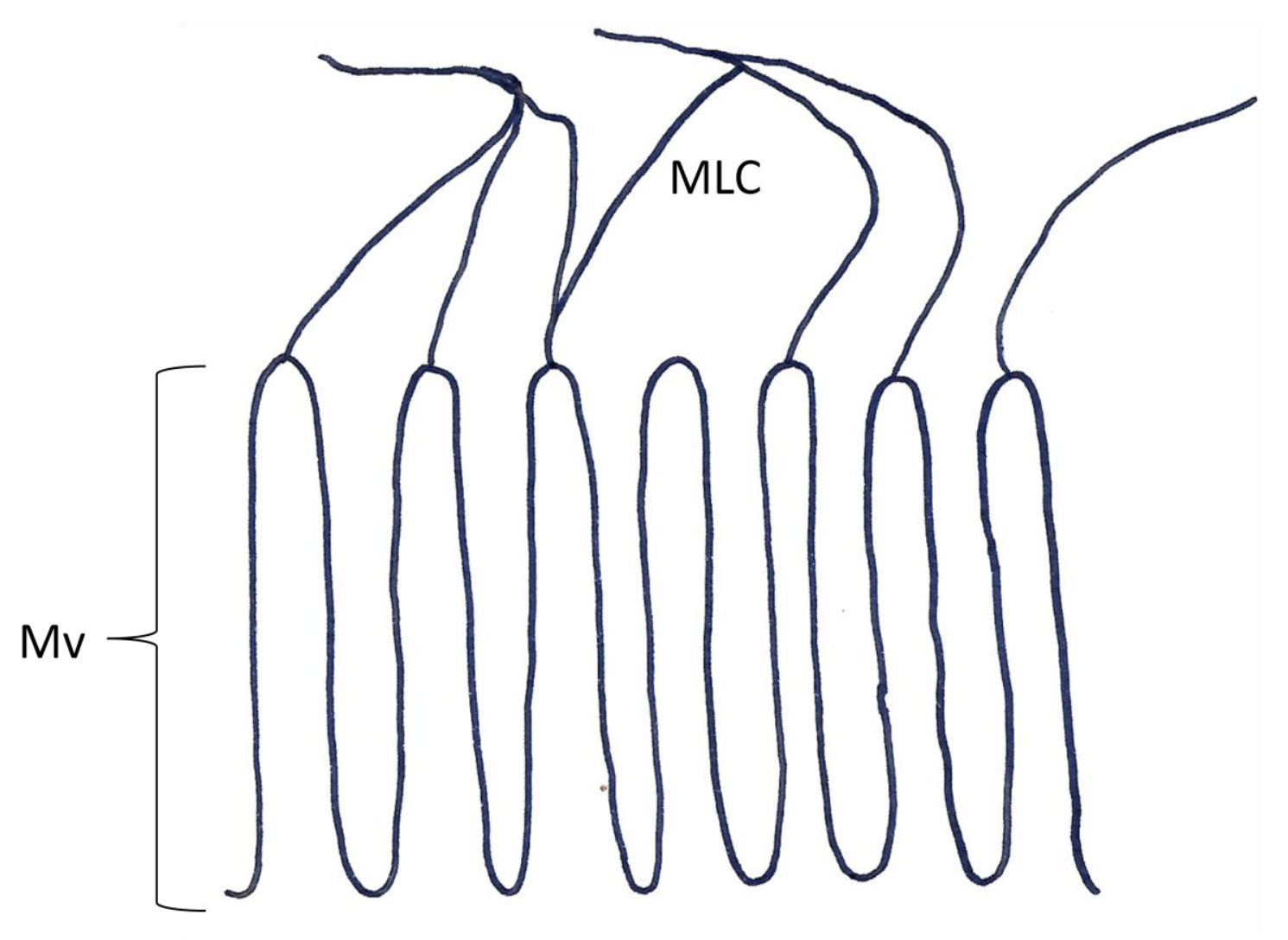


Figura 24 - Imagens ultraestruturais (MET) de $F$. vespiformes.

A - Visão geral do enterócito da espécie. Note a grande concentração de mitocôndrias próximas à região apical da célula, onde se encontram as microvilosidades.

B - Detalhe das microvilosidades em corte transversal.

C - Detalhe das microvilosidades evidenciando a organização do complexo de membranas luminais.

D - Detalhe da região basal do enterócito.

MLC - Membranas luminais em forma de chama; $L$ - Lúmen; $M v$ Microvilosidades; Mi - Mitocôndrias; LB - Lâmina basal. 

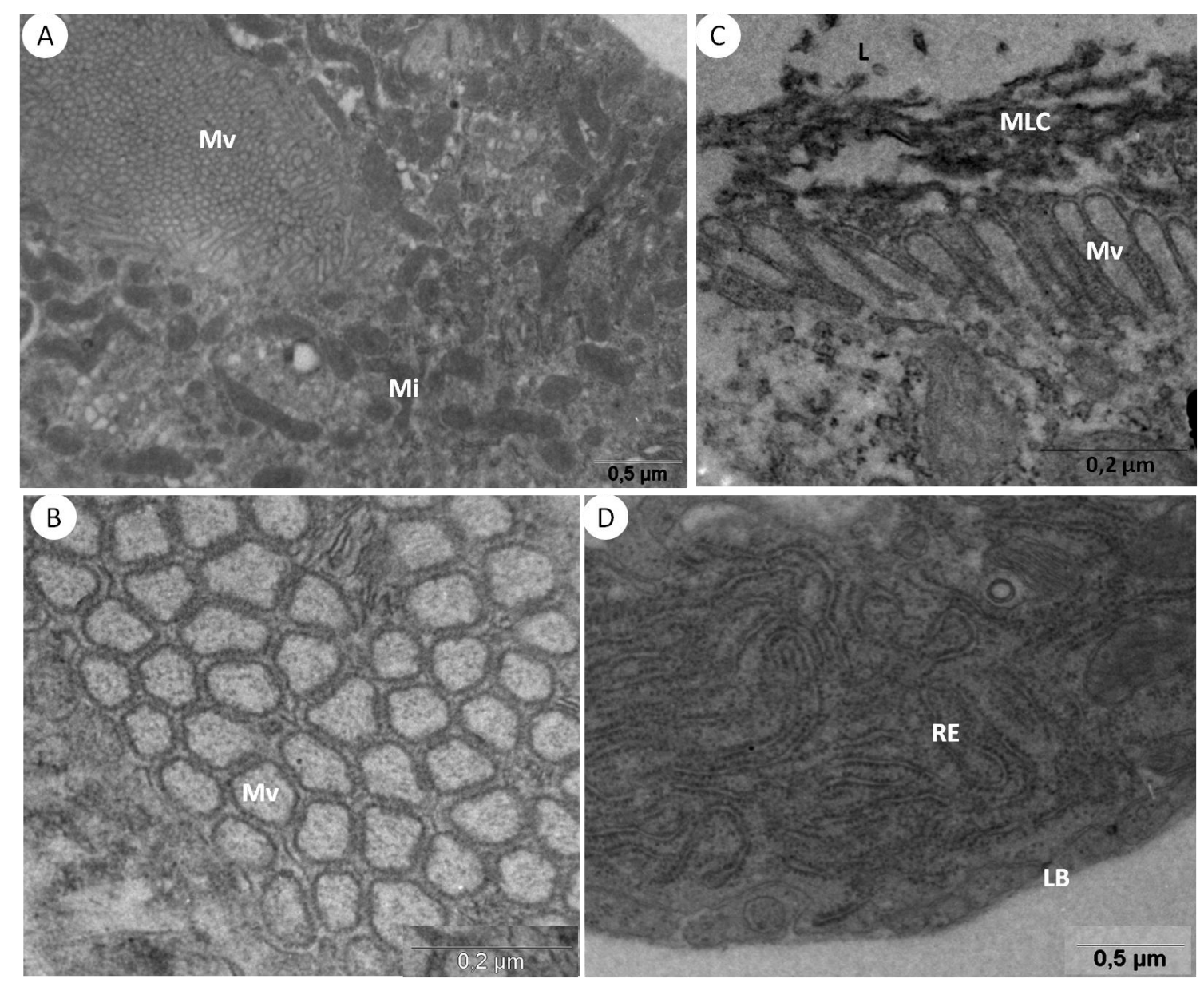
Figura 25 - Esquema da organização do complexo luminal de membranas de Franklinothrips vespiformes. As microvilosidades parecem ser revestidas em grupos, mas não individualmente pelo complexo.

Mv - Microvilosidades; MLC - Membranas luminais em forma de chama. 


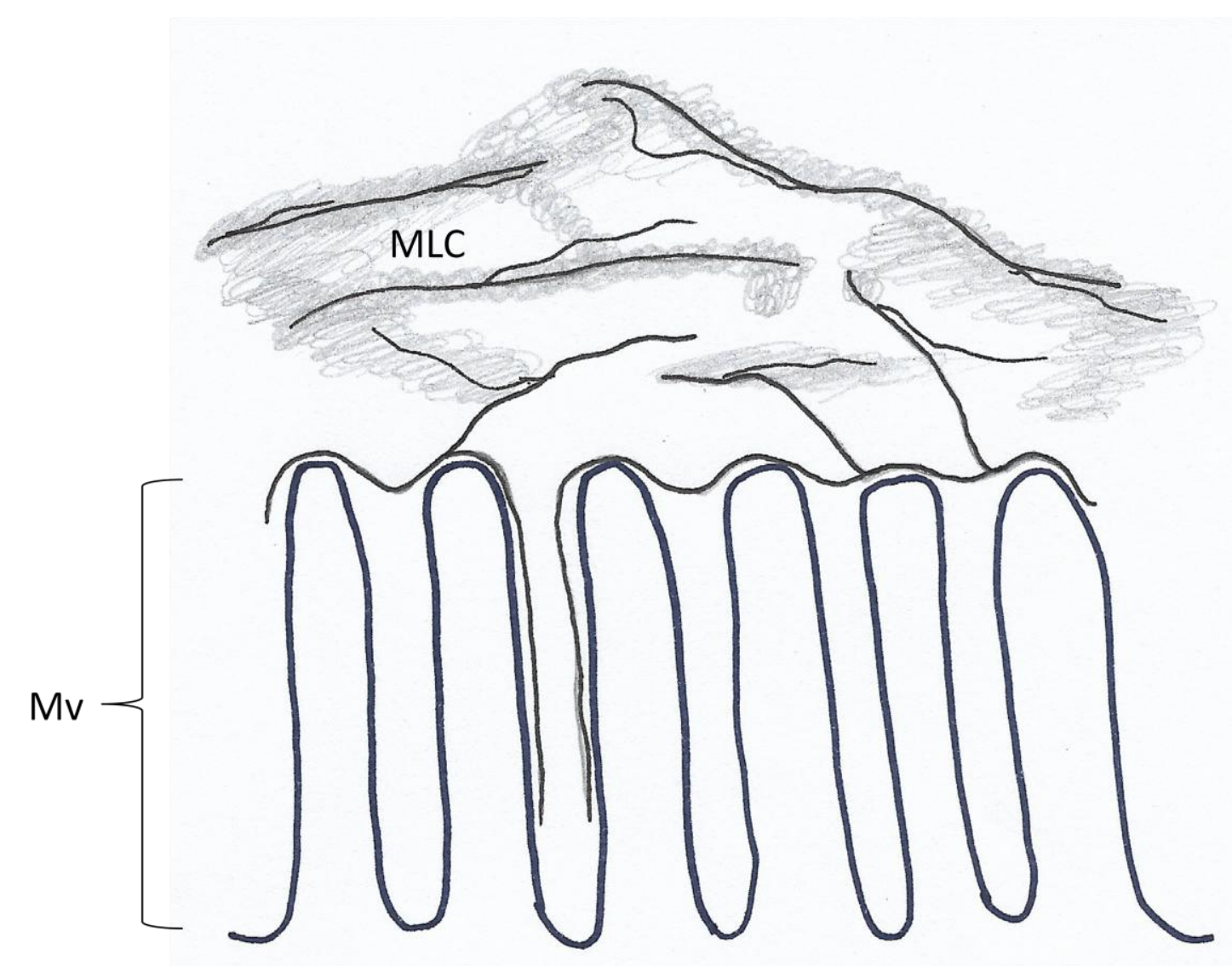


Figura 26 - Imagens ultraestruturais (MET) da região anterior do intestino médio de Liothrips $s p$.

A - Detalhe da base das microvilosidades. Note as vesículas associadas à base das microvilosidades.

B - Na imagem é possível observar a grande quantidade de vesículas e, inclusive, a presença de um corpo multivesicular (CMV) próximo ao ápice celular.

$L$ - Lúmen; $M v$ - Microvilosidades; $V$ - Vesícula; $C M V$ - Corpo multivesicular; $M i-$ Mitocôndria. 

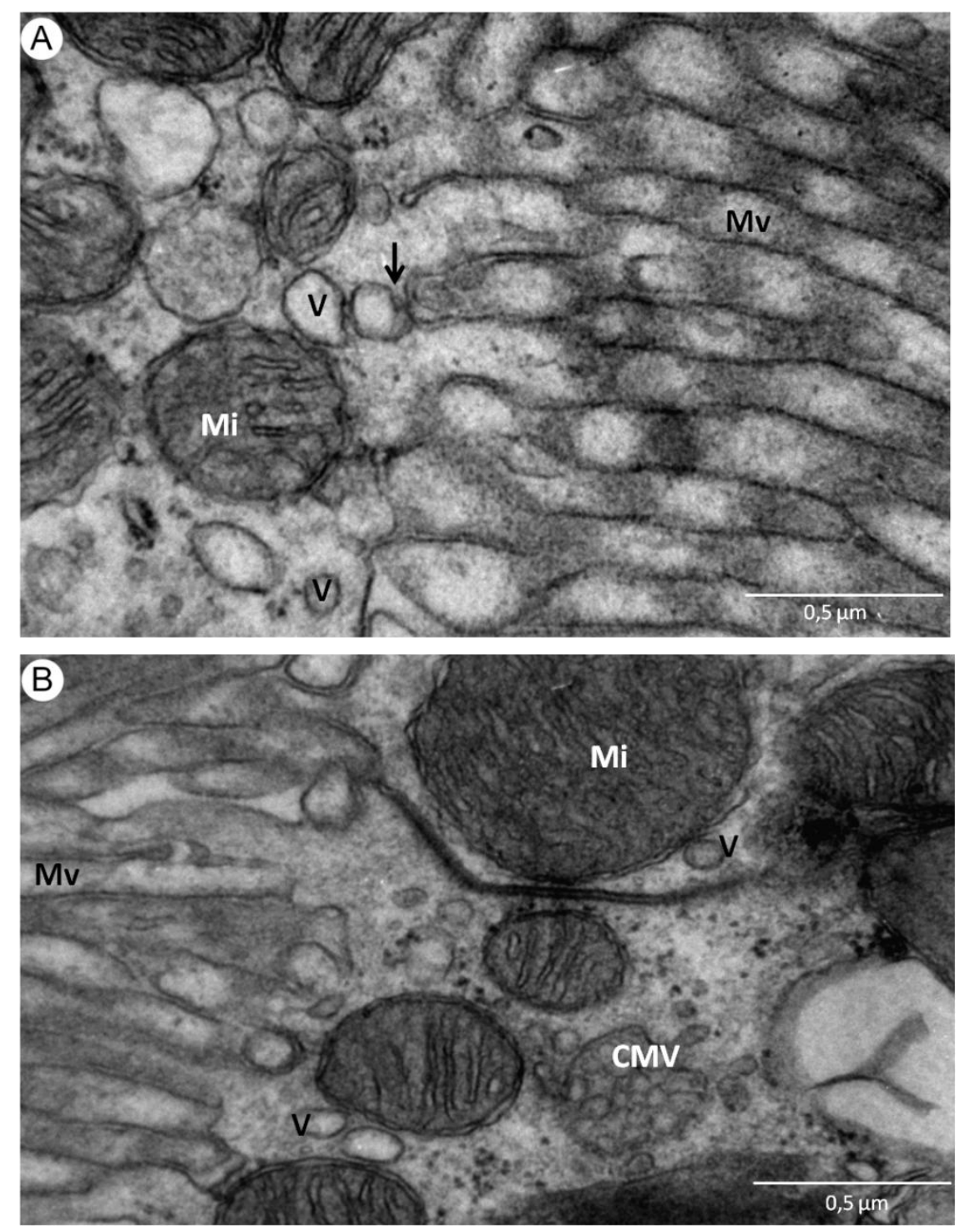
Figura 27 - Imagens ultraestruturais (MET) da região anterior do intestino médio de Liothrips $s p$.

A - Vista geral da região apical do enterócito do IMa. Observa-se uma grande quantidade de mitocôndrias próximas à base das microvilosidades que, por sua vez, apresentam uma disposição irregular, compactamente dispostas, sendo que seus ápices parecem estar conectados por membranas formando uma espécie de barreira para o lúmen

B - Detalhe da região apical evidenciando as vesículas próximas à base das microvilosidades

C - Detalhe da membrana que parece conectar os ápices das microvilosidades (seta).

L-Lúmen; $M v$ - Microvilosidades; $V$-Vesícula; Mi-Mitocôndria. 

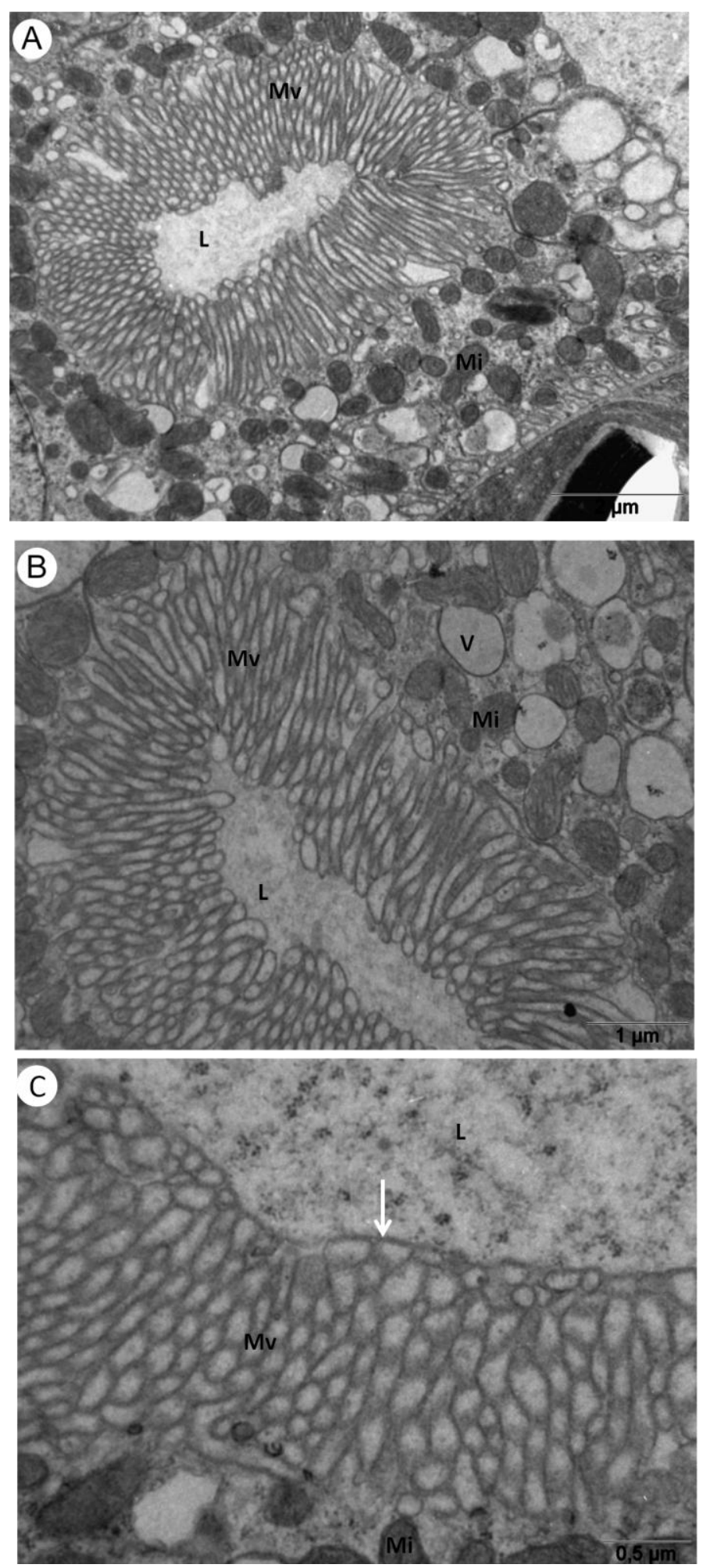
Figura 28 - Esquema da organização do complexo luminal de membranas do IMa de Liothrips sp. Não é possível observar membranas projetando-se ao lúmen, apenas uma estrutura membranosa associada ao ápice das microvilosidades que parece formar uma barreira contínua à luz do tubo (seta).

$M v$ - Microvilosidades; $V$ - Vesículas 


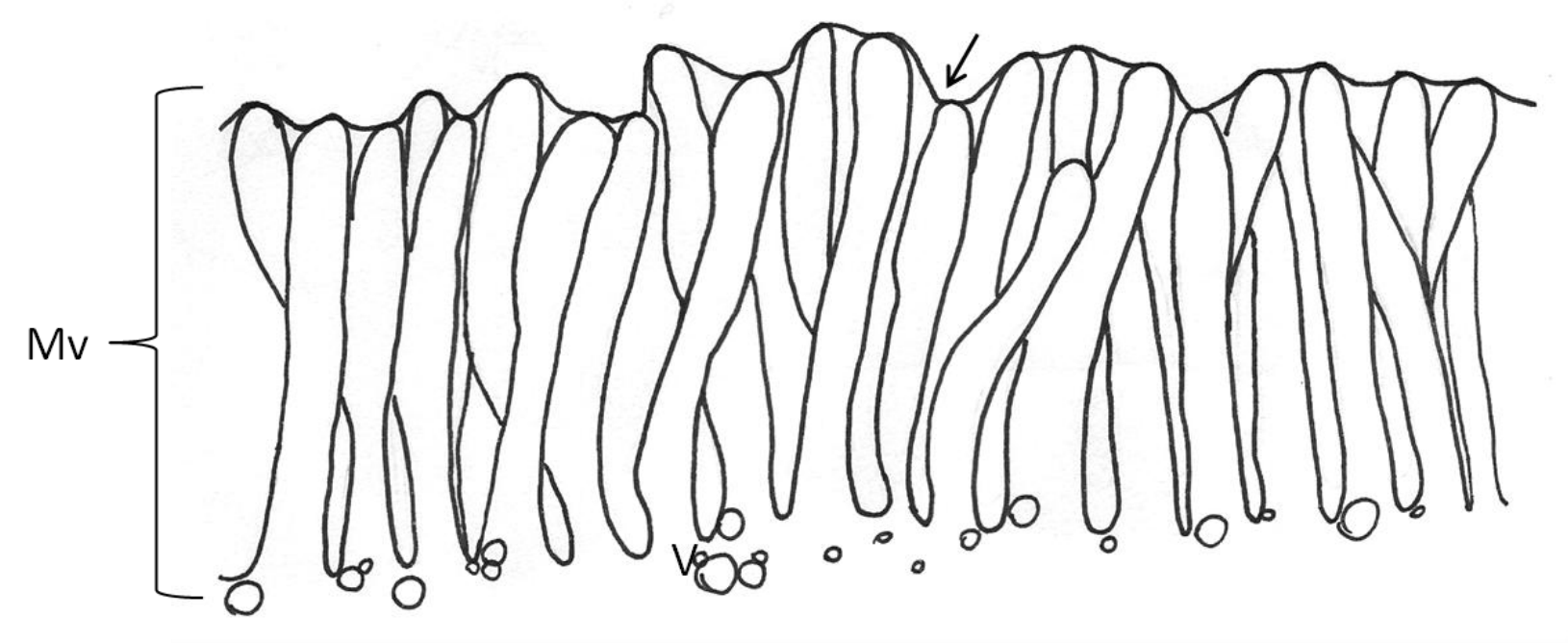


Figura 29 - Imagens ultraestruturais (MET) da região posterior do intestino médio de Liothrips sp.

A - Vista geral da região apical do enterócito. Observa-se uma grande quantidade de mitocôndrias próximas à base das microvilosidades, um núcleo evidente e a ausência de membranas associadas ao ápice das microvilosidades, no lúmen.

B - Detalhe das microvilosidades mostrando a ausência de membranas associadas e também, das vesículas encontradas em IMa..

L - Lúmen; $M v$ - Microvilosidades; $V$ - Vesícula; Mi - Mitocôndria 

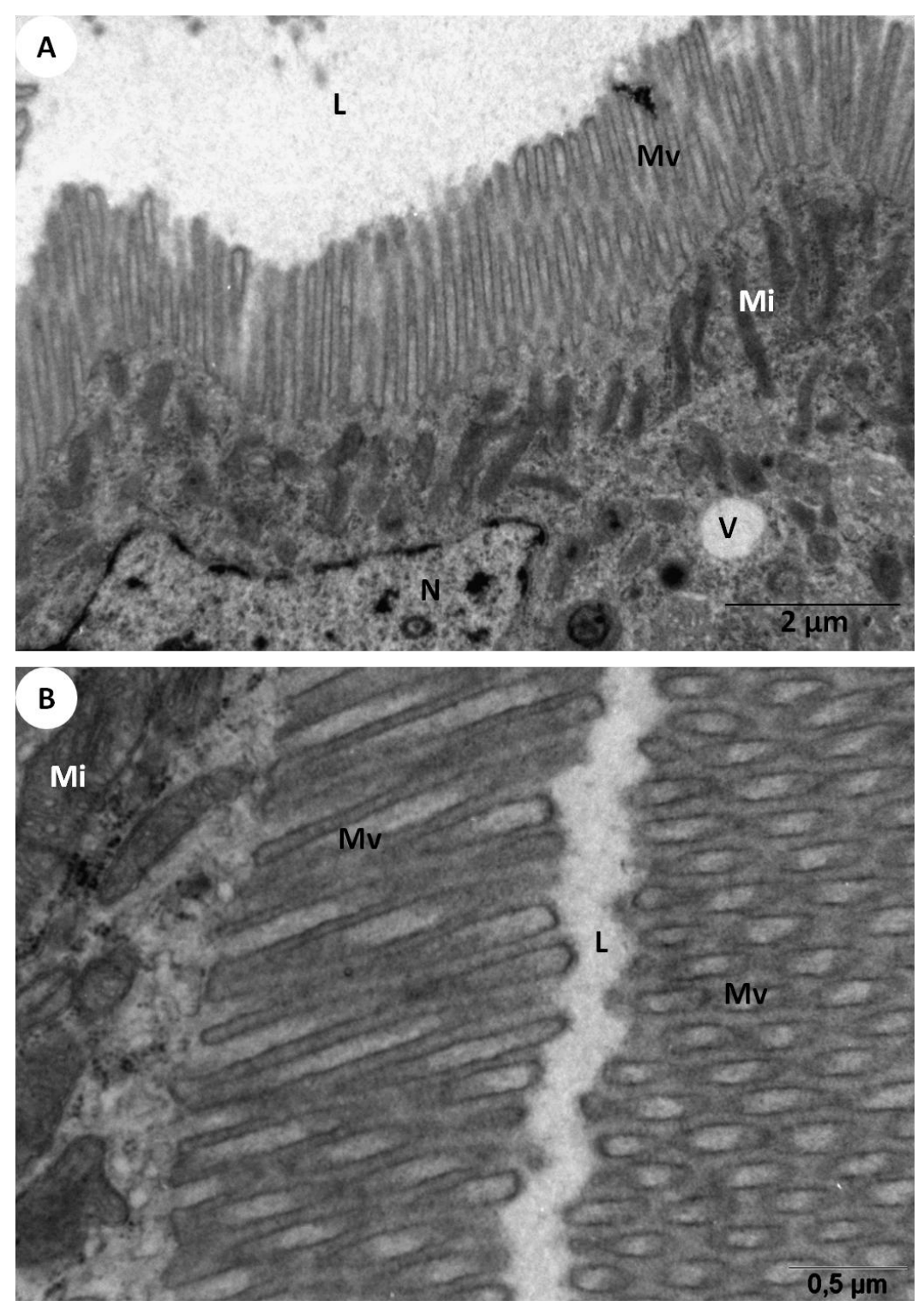
Figura 30 - Imagens ultraestruturais (MET) da região posterior do intestino médio de Liothrips sp.

A - Detalhe das microvilosidades evidenciando as estruturas similares a trabéculas que se dispõem ao longo das microvilosidades (seta).

B - Detalhe das microvilosidades em corte transversal, evidenciando a presença das trabéculas associadas (setas).

$M v$ - Microvilosidades; $M i$ - mitocôndria. 

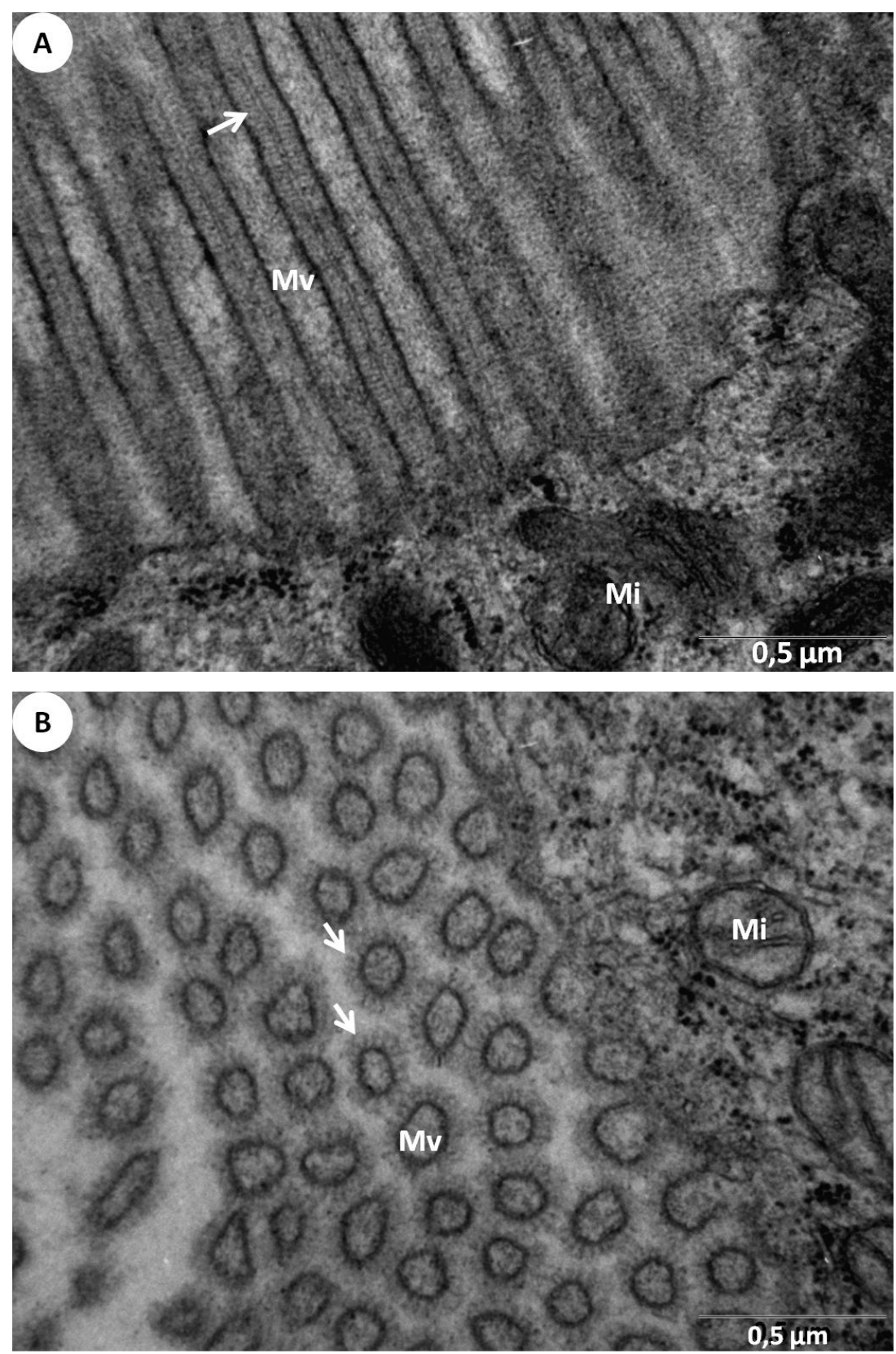
Figura 31 - Esquema da região apical dos enterócitos do IMp de Liothrips sp. caracterizada por uma ausência de um complexo luminal de membranas organizado. Note a ocorrência de trabéculas entre as microvilosidades e de pequenas membranas associadas às suas extremidades.

Mv - Microvilosidades. 


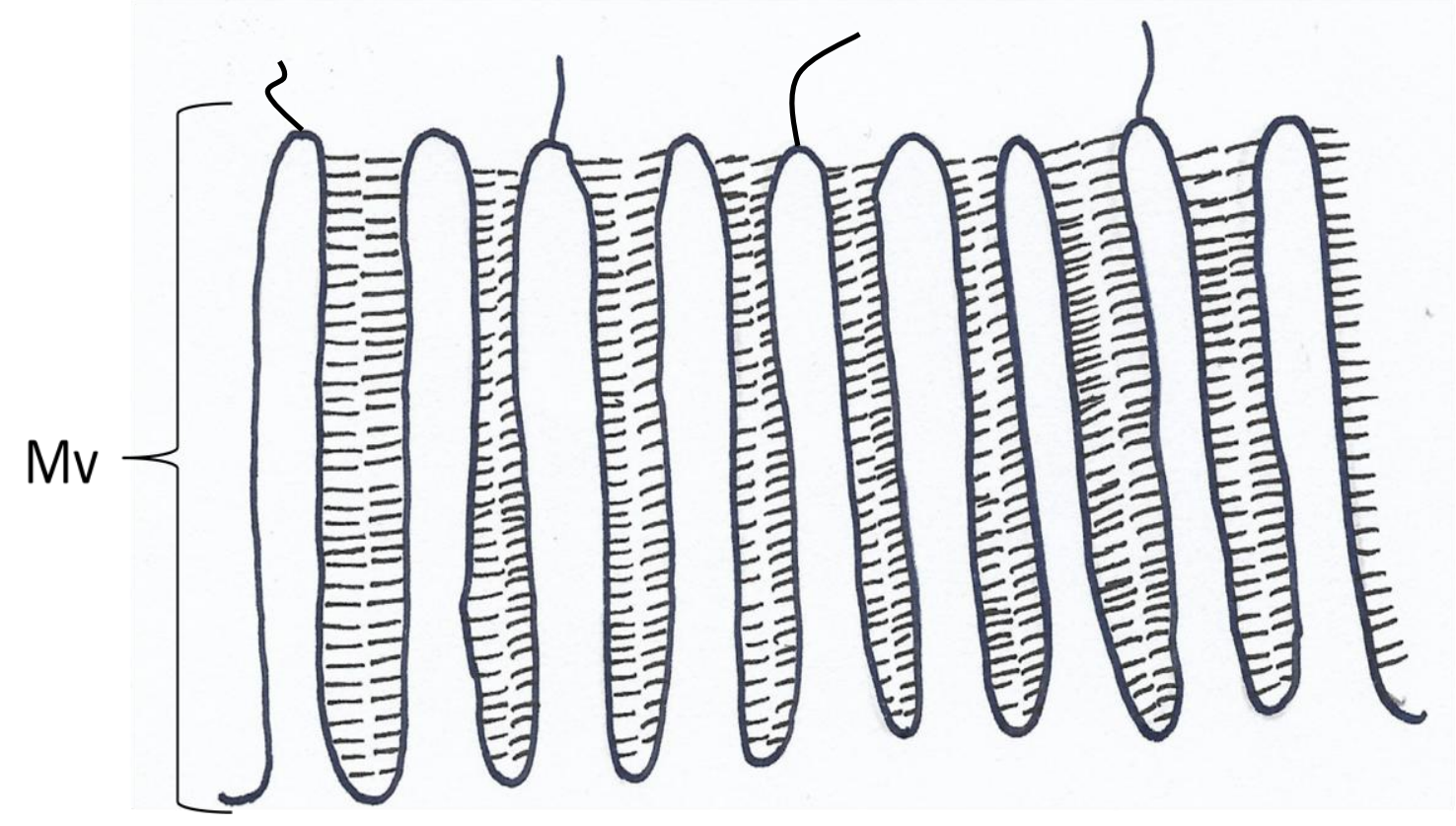


Figura 32 e 33 - Painel geral mostrando as espécies estudadas e as principais características ultraestruturais do IM de cada uma delas com relação aos complexos luminais de membranas (ausente em Liothrips sp.). 


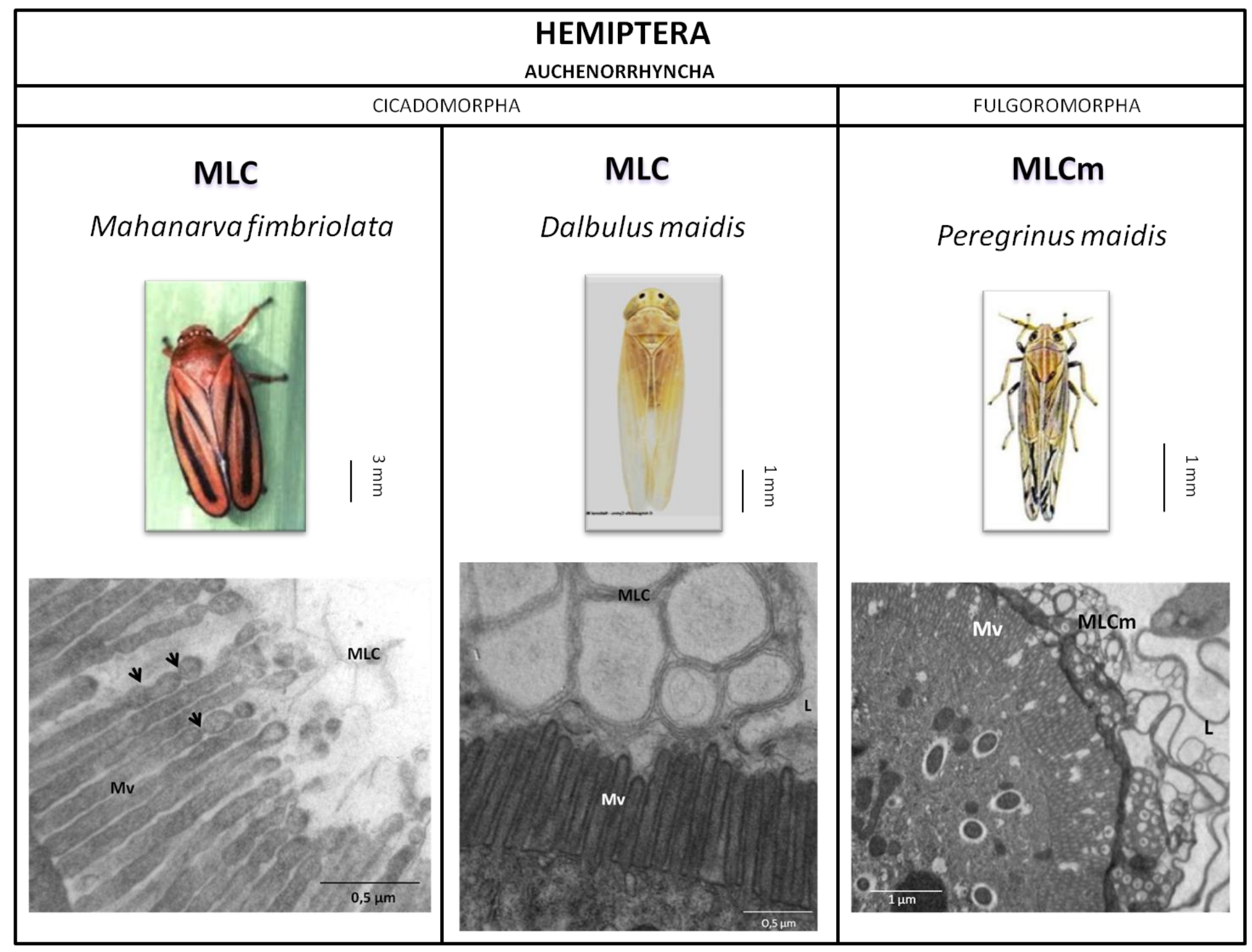




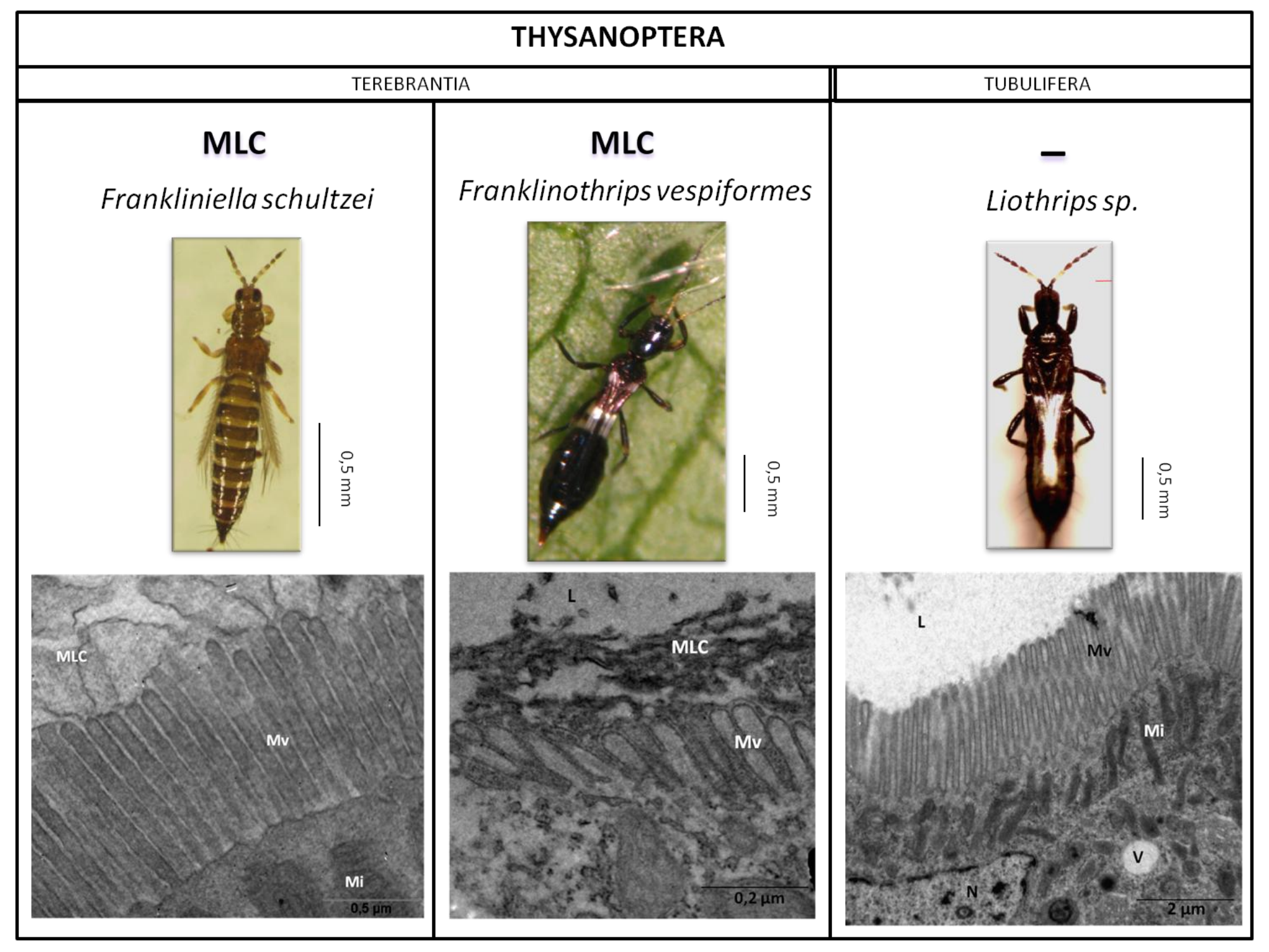

